\title{
Children First: National Guidance for the Protection and Welfare of Children
}

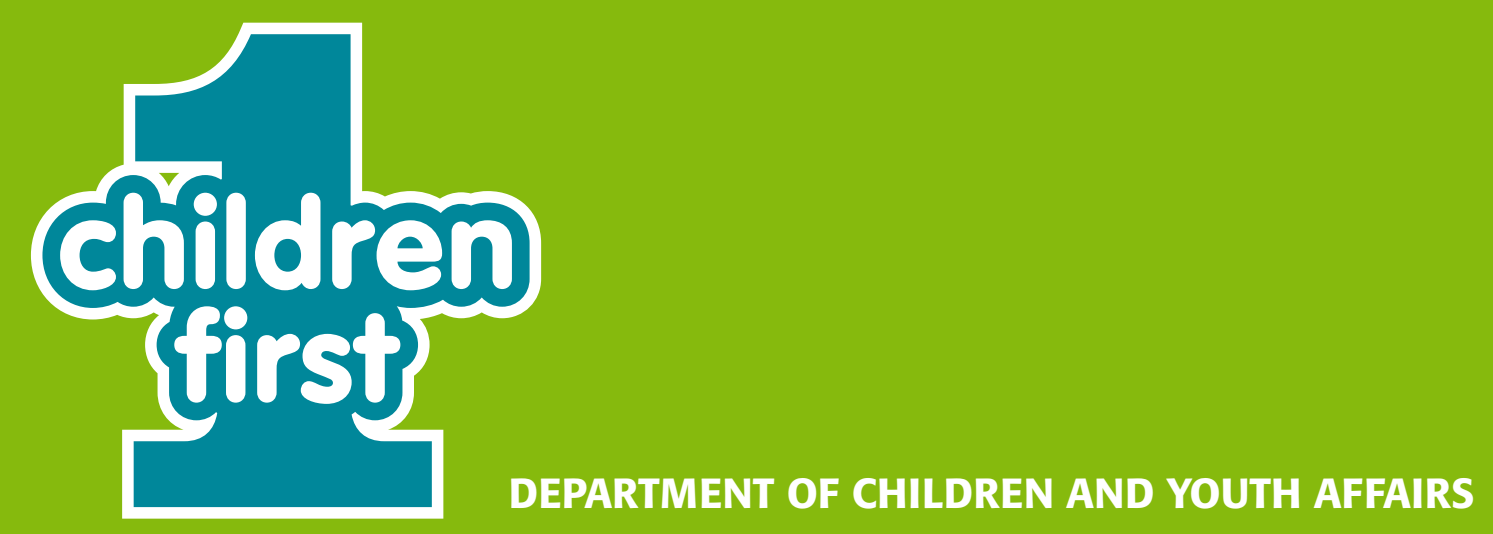





\section{Children First: National Guidance for the Protection and Welfare of Children}

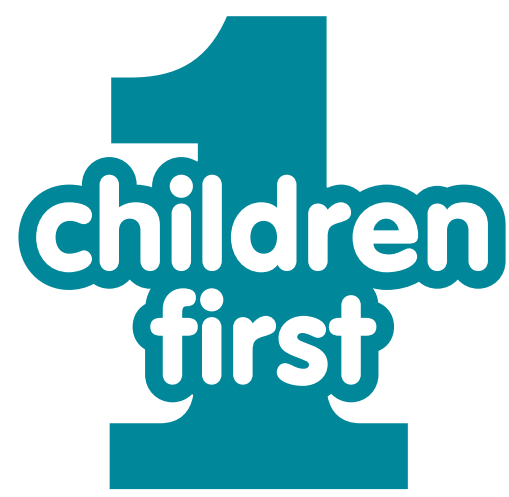

DEPARTMENT OF CHILDREN AND YOUTH AFFAIRS 
Copyright $($ Minister for Children and Youth Affairs, 2011

Department of Children and Youth Affairs

43-49 Mespil Road

Dublin 4

Tel: $+353(0) 16473000$

Fax: +353 (0) 16670826

E-mail: contact@dcya.gov.ie

Web: www.dcya.ie

Published by Government Publications, Dublin

ISBN 978-1-4064-2589-5

All rights reserved. No part of this publication may be reproduced, stored in a retrieval system, or transmitted, in any form or by any means, electronic, mechanical, photocopying, recording or otherwise, without the prior permission in writing of the copyright holder.

For rights of translation or reproduction, applications should be made to the Head of Communications, Department of Children and Youth Affairs, 43-49 Mespil Road, Dublin 4, Ireland. 


\section{This edition of Children First supersedes all others and should be the only one in use. \\ It is the reference point for practice detail.}




\section{Contents}

Minister's Foreword

\section{PART I: Key Messages}

Key Messages

1. Principles, Aims and Use of the Children First: National Guidance 4

1.1 Key principles of best practice in child protection and welfare 4

1.2 Aims of the Children First: National Guidance 4

1.3 Use of the Children First: National Guidance 5

\section{PART II: Definitions and Recognition of Child Abuse; Basis for reporting concerns and Standard Reporting Procedure; Interagency Cooperation}

2. Definition and Recognition of Child Abuse 8

2.1 Types of child abuse 8

2.2 Definition of 'neglect' 8

2.3 Definition of 'emotional abuse' $\quad 8$

2.4 Definition of 'physical abuse' 9

2.5 Definition of 'sexual abuse' 9

2.6 Recognising child neglect or abuse $\quad 10$

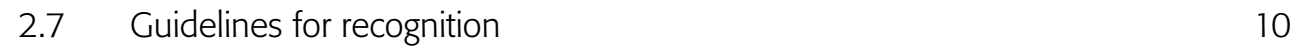

2.8 Children with additional vulnerabilities 11

2.9 Fatal child abuse $\quad 11$

2.10 Points to remember 12

3. Basis for reporting concerns and Standard Reporting Procedure 13

$\begin{array}{lll}3.1 & \text { Purpose } & 13\end{array}$

3.2 Responsibility to report child abuse or neglect 13

3.3 Designated Liaison Persons for reporting neglect or abuse 14

3.4 Standard Reporting Procedure 14

3.5 Information to be included when making a report 14

3.6 Retrospective disclosures by adults $\quad 15$

3.7 Deciding to share child protection concerns $\quad 15$

3.8 Cases not reported to the HSE or An Garda Síochána 16

3.9 Confidentiality 16

3.10 Legal protection 16

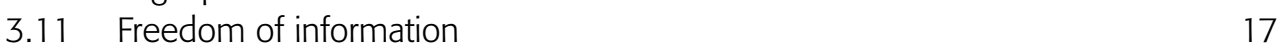

4. Interagency Cooperation: Roles and responsibilities of organisations and personnel working with children

4.1 Purpose

4.2 Roles and responsibilities of Central Government

4.3 Benefits of interagency cooperation and exchange of information in relation to child protection and welfare

4.4 Roles and responsibilities of the HSE Children and Family Services

4.6 Cooperation between An Garda Síochána and the HSE Children and Family Services

4.7 Roles and responsibilities of Other Statutory Agencies and Non-statutory Organisations

4.8 Roles and responsibilities of Schools 
ROLES AND RESPONSIBILITIES OF THE HEALTH SECTOR

4.9 Roles and responsibilities of General Practitioners and Primary Care Teams 23

4.10 Roles and responsibilities of Hospitals 24

4.11 Roles and responsibilities of Mental Health and Addiction Services 25

4.12 Roles and responsibilities of Child and Adolescent Psychiatry Services 25

4.13 Roles and responsibilities of Private Healthcare Providers and

Non-statutory Providers of services to children

$\begin{array}{lll}4.14 & \text { Roles and responsibilities of Other Health Professionals } & 26 \\ 4.15 & \text { Roles and responsibilities of Other Statutory Organisations }\end{array}$

\section{PART III: Guidance for HSE Children and Family Services and Other Professionals; Protocol for An Garda Síochána - HSE Liaison}

5. Assessment and Management of child protection and welfare concerns GENERAL GUIDELINES

$\begin{array}{lll}5.1 & \text { Purpose } & 3 \\ 5.2 & \text { Referral and Assessment } & 3 \\ 5.3 & \text { Screening and Preliminary Enquiries } & 3 \\ 5.4 & \text { Initial Assessment } & 3 \\ 5.5 & \text { Unfounded concerns } & 32 \\ 5.6 & \text { Provision of child welfare services } & 32 \\ 5.7 & \text { Strategy Meeting } & 33 \\ 5.8 & \text { Child Protection Conference } & 3 \\ 5.9 & \text { Child Protection Plan } & 34 \\ 5.10 & \text { Appointment of a key worker } & 35 \\ 5.11 & \text { Child Protection Review Conference } & 36 \\ 5.12 & \text { Emergency action to protect a child } & 36 \\ 5.13 & \text { Closure of cases } & 37 \\ 5.14 & \text { Responsibility of the HSE Children and Family Services } & 3 \\ 5.15 & \text { Confidentiality and anonymity } & 38 \\ 5.16 & \text { Response to persons reporting concerns } & 39 \\ 5.17 & \text { Child Protection Notification System } & 39 \\ 5.18 & \text { Medical/Specialist examinations } & 40 \\ 5.19 & \text { Case transfer } & 40 \\ 5.20 & \text { Serious Incident Reviews } & 40 \\ 5.21 & \text { Record-keeping } & 4\end{array}$

6. Supervision, Support and Additional Guidance for HSE child protection and welfare work

6.1 Corporate risk strategy and staff supervision and support policy in the HSE

6.2 Guidance on allegations against employees and volunteers

6.3 Guidance on interviewing parents/carers

6.4 Guidance on interviewing children

6.5 Conflict between parents/carers and children

7. Protocol for An Garda Síochána - HSE Liaison

7.1 Introduction

7.2 Designated personnel

7.3 Tracking systems

7.4 Cases to be formally notified by the HSE to An Garda Síochána

7.5 Informal consultation

7.6 Emergency intervention

7.7 Cases to be formally notified by An Garda Síochána to the HSE 48

7.8 Informal consultation

7.9 Emergency intervention

7.10 Assessment and Investigation of cases

7.11 Matters to be considered by the HSE and An Garda Síochána during the assessment, investigation and management of suspected child abuse cases 
$\begin{array}{lll}7.12 & \text { Confidentiality } & 50\end{array}$

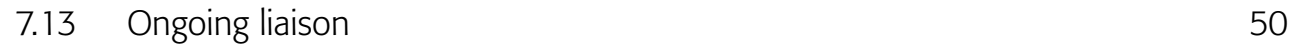

7.14 Strategy Meeting 51

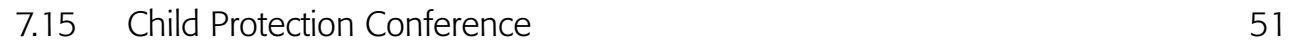

7.16 Special considerations 51

7.17 Arrangements for the protection of children at risk in other areas or jurisdictions

7.18 Arrangements for the protection of children at risk who migrate to Ireland from another jurisdiction

\section{PART IV: Special Considerations}

8. Especially vulnerable children

8.1 Purpose 56

8.2 Role of the HSE $\quad 56$

8.3 Role of the HIQA and SSI 56

8.4 Children in residential, educational and recreational settings 56

8.5 Safeguarding children in residential settings 57

8.6 Abuse of children in residential settings by visitors 57

8.7 Abuse or neglect of children in residential settings by staff 57

8.8 Children in the care of the State under the Child Care Act 1991

8.9 Other vulnerable children 58

8.10 Children who are homeless 58

$\begin{array}{lr}\text { 9. } & \text { Peer abuse } \\ \end{array}$

$\begin{array}{lll}9.1 & \text { Purpose } & 60\end{array}$

9.2 General guidelines 60

9.3 Sexual abuse by children and young people 60

$\begin{array}{lll}9.4 & \text { Bullying } & 61\end{array}$

10. Training in child protection and welfare 62

$\begin{array}{lll}10.1 & \text { Purpose } & 62\end{array}$

10.2 Objectives of child protection and welfare training 62

10.3 Approach to child protection and welfare training 62

$\begin{array}{lll}10.4 & \text { Target groups } & 63\end{array}$

10.5 Interagency training 63

$\begin{array}{ll}\text { References and Official Websites } & 65\end{array}$

\section{Appendices}

Appendix 1: Signs and symptoms of child abuse $\quad 70$

Appendix 2: National contacts for HSE Children and Family Services 75

Appendix 3: Standard Report Form for reporting child protection and/or welfare concerns to the HSE

Appendix 4: Standard Notification Form for use by the HSE in notifying cases to An Garda Síochána

Appendix 5: Standard Notification Form for use by An Garda Síochána in notifying cases to the HSE

Appendix 6: Record of Garda - HSE Liaison Form 83

Appendix 7: Relevant Legislation $\quad 90$

Appendix 8: Guidance for developing local child protection and welfare procedures 92

Appendix 9: Guidance for employers dealing with an allegation of abuse 93

Appendix 10: List of HSE Designated Officers - Protections for Persons Reporting Child Abuse Act 1998 


\section{Minister's Foreword}

The Department of Children and Youth Affairs has a number of responsibilities, obligations and duties in relation to the youngest citizens of our country. Paramount among these is ensuring their safety.

No childhood should be shattered by abuse. No young life should be lived in the shadow of fear. While it is not possible to prevent all violence, nor possible to guarantee that no child will ever be harmed by neglect or aggression or exploitation or predation, it is our duty to do everything in our power as a Government and as a society to prevent such harm.

This begins by ensuring that children are safe and protected in all aspects of their lives - where they live, learn, pray and play. This Children First: National Guidance for the Protection and Welfare of Children and the accompanying Child Protection and Welfare Practice Handbook set out clearly how child protection must be placed at the core of any organisation working with children. The documents detail what is to be done to protect children, how it is to be done and who are the key people in each organisation to do it.

This combination of the Children First: National Guidance 2011, as the comprehensive reference document, and a practical handbook to key actions for front-line practitioners will deliver a sound footing for national consistency in our approach to child protection.

These changes and the creation of a dedicated National Child and Family Support Agency, for the provision of family support and child protection services, will result in greatly enhanced protection for children.

Ultimately, it is our intention to update all available guidelines to take account of the new National Agency, its functions and duties, and to reflect the best of practice from Ireland and internationally. The new roles and responsibilities will be supported by the Children First: National Guidance and a substantial implementation programme, training and audit of compliance and impact to ensure national application of best practice.

Guidelines cannot eradicate evil. Audits cannot prevent exploitation. Our task is not to delude ourselves that every malign aspect of humanity can be removed; rather, it is to ensure that children are protected from the badness in society. Where we fail, where abuse occurs despite our best efforts, our task is to make sure that the abusers are caught, punished and prevented from re-offending, and to make sure that those who facilitated the crime, either by commission or omission, are held to account.

We intend to enact legislation so that all people who are working with children will have a statutory duty to comply with the Children First: National Guidance. This is a significant step forward in the protection of children from abuse. It will result in more effective interagency cooperation and will provide for a more consistent and strong system for the protection of children.

Frances Fitzgerald, TD

Minister for Children and Youth Affairs 
PART I: Key Messages 


\section{Key Messages}

The aim of the Children First: National Guidance is to promote the safety and well-being of children. Parents and guardians have the primary responsibility for the care and protection of children. Many parents from time to time require support and help from the State in carrying out their parental role.

Some parents, for a range of reasons, are not able to provide proper care for their children. These families need more intensive assessment, support and direct interventions to ensure the safety and well-being of their children. People working with children and the wider public should know that early action by them is very often the best way to protect children and to enable a family to stay together. Professionals also have an important part to play and their actions need to reflect the principles and objectives of the Child Care Act 1991 and of this national guidance.

Professionals and others working with children need to pay particular attention to the needs of children who may be at risk of abuse. Research tells us that children whose parents misuse drugs or alcohol are more at risk of neglect or maltreatment. Parents who have a learning disability or mental illness may need particular support in carrying out their parenting role.

Research indicates that most abuse occurs in the family home. Children may be abused by persons other than those living in the immediate family. This may happen where a child is in contact with a relative, a family friend or acquaintance, or a person whose professional or voluntary activity brings them into contact with a child. In all instances, the best interests and safety of the child must be prioritised.

Good practice at the front line is based on clear policies and principles. The Government's policy underpinning this Children First: National Guidance is:

- the welfare and safety of children, which is central to all Government policy;

- the promotion of and support for family life;

- the use of the minimum necessary intervention, in a timely way, to keep children safe;

- agencies working together to help children reach their full potential;

- agencies working together to provide safer and more effective services;

- the State and civil society working together to promote children's welfare.

This national guidance sets out the particular statutory responsibility of the HSE Children and Family Services and An Garda Síochána when they are alerted to concerns about the welfare and safety of a child.

The broader group of health, educational and other professionals and organisations, including voluntary groups, whose work brings them into contact with children and families also have a responsibility to be aware of the signs, symptoms and possibilities of neglect and abuse. They need to share their concerns or seek advice from the HSE, make a formal report and cooperate in whatever way possible, including attending at meetings, in order to share information and contribute to good decision-making. In an emergency situation, the Gardaí should be informed of children at risk.

The wider community of relatives, friends, and neighbours are well placed to be aware of a child's welfare and need to know how to respond to ensure the most effective steps are taken to protect a child. 
As a member of the public, if you have concerns about a child but are not sure what to do, or if you are worried about a child's safety or welfare, you should contact your local HSE Children and Family Services (see HSE nationwide contacts in Appendix 2).

Professionals and those involved in organisations working with children who have concerns about a child but are not sure what to do should discuss these with the Children First designated person in your organisation or contact the HSE Children and Family Services for advice (see Appendix 2).

If you think a child is in immediate danger and you cannot contact the HSE Children and Family Services, you should contact the Gardaí at any Garda station. 


\section{Principles, Aims and Use of the Children First: National Guidance}

\subsection{Key principles of best practice in child protection and welfare}

1.1.1 The key principles that should inform best practice in child protection and welfare are:

(i) The welfare of children is of paramount importance.

(ii) Early intervention and support should be available to promote the welfare of children and families, particularly where they are vulnerable or at risk of not receiving adequate care or protection. Family support should form the basis of early intervention and preventative interventions.

(iii) A proper balance must be struck between protecting children and respecting the rights and needs of parents/carers and families. Where there is conflict, the child's welfare must come first.

(iv) Children have a right to be heard, listened to and taken seriously. Taking account of their age and understanding, they should be consulted and involved in all matters and decisions that may affect their lives. Where there are concerns about a child's welfare, there should be opportunities provided for their views to be heard independently of their parents/carers.

(v) Parents/carers have a right to respect and should be consulted and involved in matters that concern their family.

(vi) Factors such as the child's family circumstances, gender, age, stage of development, religion, culture and race should be considered when taking protective action. Intervention should not deal with the child in isolation; the child's circumstances must be understood within a family context.

(vii) The criminal dimension of any action must not be ignored.

(viii) Children should only be separated from parents/carers when alternative means of protecting them have been exhausted. Re-union should be considered in the context of planning for the child's future.

(ix) The prevention, detection and treatment of child abuse or neglect requires a coordinated multidisciplinary approach, effective management, clarity of responsibility and training of personnel in organisations working with children.

(x) Professionals and agencies working with adults who for a range of reasons may have serious difficulties meeting their children's basic needs for safety and security should always consider the impact of their adult client/patient's behaviour on a child and act in the child's best interests.

\subsection{Aims of the Children First: National Guidance}

1.2.1 The Children First: National Guidance is intended to assist people in identifying and reporting child abuse and neglect and deal effectively with concerns. It emphasizes that the needs of children and families must be at the centre of child protection and welfare services, and that the welfare of children is of paramount importance. It highlights the roles and responsibilities of the HSE and An Garda Síochána, which are the two agencies with statutory responsibility for child protection. It also offers guidance to agencies and community and voluntary organisations (e.g. religious/faith sector, sporting organisations, etc) that have contact with or provide services to children.

1.2.2 Society has a duty of care towards children and everyone should be alert to the possibility that children with whom they are in contact may be being abused or at risk of being abused. This national guidance is designed to encourage people to report concerns or suspicions to the HSE Children and Family Services. 
1.2.3 The national guidance is also intended to provide a framework to support interagency cooperation and the strengthening of multidisciplinary responses to child abuse and neglect. Effective child protection will be best achieved where the national guidance and local procedures are underpinned by comprehensive training, supervision and support services for children and their families.

\subsection{Use of the Children First: National Guidance}

1.3.1 Consistent with the principles of Children First, every organisation, both public and private, that is providing services for children or that is in regular direct contact with children should:

(i) ensure best practice in the recruitment of staff or volunteers, which includes Garda vetting, taking up of references, good HR practices in interviewing, induction training, probation and ongoing supervision and management;

(ii) ensure that staff members or volunteers are aware of how to recognise signs of child abuse or neglect;

(iii) develop guidance and procedures for staff and/or volunteers who may have reasonable grounds for concern about the safety and welfare of children involved with the organisation. These procedures should not deviate from the current Children First: National Guidance, but may offer further elaboration to ensure local relevance and applicability (see Appendix 8 for further guidance). It is the responsibility of each organisation to ensure that such guidance and procedures are in place;

(iv) identify a designated person to act as a liaison with outside agencies and a resource person to any staff member or volunteer who has child protection concerns. The designated person is responsible for reporting allegations or suspicions of child abuse to the HSE Children and Family Services or to An Garda Síochána. 


\section{PART II: Definitions and Recognition of Child Abuse}

Basis for reporting concerns and Standard Reporting Procedure

Interagency Cooperation 


\section{Definition and Recognition of Child Abuse}

\subsection{Types of child abuse}

2.1.1 This chapter outlines the principal types of child abuse and offers guidance on how to recognise such abuse. Child abuse can be categorised into four different types: neglect, emotional abuse, physical abuse and sexual abuse. A child may be subjected to one or more forms of abuse at any given time. More

\section{detail on each type of abuse is given in Appendix 1.}

2.1.2 In the Children First: National Guidance, 'a child' means a person under the age of 18 years, excluding a person who is or has been married.

\subsection{Definition of 'neglect'}

2.2.1 Neglect can be defined in terms of an omission, where the child suffers significant harm or impairment of development by being deprived of food, clothing, warmth, hygiene, intellectual stimulation, supervision and safety, attachment to and affection from adults, and/or medical care.

2.2.2 Harm can be defined as the ill-treatment or the impairment of the health or development of a child. Whether it is significant is determined by the child's health and development as compared to that which could reasonably be expected of a child of similar age.

2.2.3 Neglect generally becomes apparent in different ways over a period of time rather than at one specific point. For example, a child who suffers a series of minor injuries may not be having his or her needs met in terms of necessary supervision and safety. A child whose height or weight is significantly below average may be being deprived of adequate nutrition. A child who consistently misses school may be being deprived of intellectual stimulation.

2.2.4 The threshold of significant harm is reached when the child's needs are neglected to the extent that his or her well-being and/or development are severely affected.

\subsection{Definition of 'emotional abuse'}

2.3.1 Emotional abuse is normally to be found in the relationship between a parent/carer and a child rather than in a specific event or pattern of events. It occurs when a child's developmental need for affection, approval, consistency and security are not met. Unless other forms of abuse are present, it is rarely manifested in terms of physical signs or symptoms. Examples may include:

(i) the imposition of negative attributes on a child, expressed by persistent criticism, sarcasm, hostility or blaming;

(ii) conditional parenting in which the level of care shown to a child is made contingent on his or her behaviours or actions;

(iii) emotional unavailability of the child's parent/carer;

(iv) unresponsiveness of the parent/carer and/or inconsistent or inappropriate expectations of the child;

(v) premature imposition of responsibility on the child;

(vi) unrealistic or inappropriate expectations of the child's capacity to understand something or to behave and control himself or herself in a certain way;

(vii) under- or over-protection of the child;

(viii) failure to show interest in, or provide age-appropriate opportunities for, the child's cognitive and emotional development; 
(ix) use of unreasonable or over-harsh disciplinary measures;

(x) exposure to domestic violence;

(xi) exposure to inappropriate or abusive material through new technology.

2.3.2 Emotional abuse can be manifested in terms of the child's behavioural, cognitive, affective or physical functioning. Examples of these include insecure attachment, unhappiness, low self-esteem, educational and developmental underachievement, and oppositional behaviour. The threshold of significant harm is reached when abusive interactions dominate and become typical of the relationship between the child and the parent/carer.

\subsection{Definition of 'physical abuse'}

2.4.1 Physical abuse of a child is that which results in actual or potential physical harm from an interaction, or lack of interaction, which is reasonably within the control of a parent or person in a position of responsibility, power or trust. There may be single or repeated incidents.

Physical abuse can involve:

(i) severe physical punishment;

(ii) beating, slapping, hitting or kicking;

(iii) pushing, shaking or throwing;

(iv) pinching, biting, choking or hair-pulling;

(v) terrorising with threats;

(vi) observing violence;

(vii) use of excessive force in handling;

(viii) deliberate poisoning;

(ix) suffocation;

(x) fabricated/induced illness (see Appendix 1 for details);

(xi) allowing or creating a substantial risk of significant harm to a child.

\subsection{Definition of 'sexual abuse'}

2.5.1 Sexual abuse occurs when a child is used by another person for his or her gratification or sexual arousal, or for that of others. Examples of child sexual abuse include:

(i) exposure of the sexual organs or any sexual act intentionally performed in the presence of the child;

(ii) intentional touching or molesting of the body of a child whether by a person or object for the purpose of sexual arousal or gratification;

(iii) masturbation in the presence of the child or the involvement of the child in an act of masturbation;

(iv) sexual intercourse with the child, whether oral, vaginal or anal;

(v) sexual exploitation of a child, which includes inciting, encouraging, propositioning, requiring or permitting a child to solicit for, or to engage in, prostitution or other sexual acts. Sexual exploitation also occurs when a child is involved in the exhibition, modeling or posing for the purpose of sexual arousal, gratification or sexual act, including its recording (on film, video tape or other media) or the manipulation, for those purposes, of the image by computer or other means. It may also include showing sexually explicit material to children, which is often a feature of the 'grooming' process by perpetrators of abuse; 
(vi) consensual sexual activity involving an adult and an underage person. In relation to child sexual abuse, it should be noted that, for the purposes of the criminal law, the age of consent to sexual intercourse is 17 years for both boys and girls. An Garda Síochána will deal with the criminal aspects of the case under the relevant legislation.

2.5.2 It should be noted that the definition of child sexual abuse presented in this section is not a legal definition and is not intended to be a description of the criminal offence of sexual assault.

\subsection{Recognising child neglect or abuse}

2.6.1 Child neglect or abuse can often be difficult to identify and may present in many forms. A list of indicators of child abuse is contained in Appendix 1. No one indicator should be seen as conclusive in itself of abuse. It may indicate conditions other than child abuse. All signs and symptoms must be examined in the context of the child's situation and family circumstances.

\subsection{Guidelines for recognition}

2.7.1 The ability to recognise child abuse can depend as much on a person's willingness to accept the possibility of its existence as it does on their knowledge and information. There are commonly three stages in the identification of child neglect or abuse:

(i) considering the possibility;

(ii) looking out for signs of neglect or abuse;

(iii) recording of information.

\section{Stage 1: Considering the possibility}

2.7.2 The possibility of child abuse should be considered if a child appears to have suffered a suspicious injury for which no reasonable explanation can be offered. It should also be considered if the child seems distressed without obvious reason or displays persistent or new behavioural problems. The possibility of child abuse should also be considered if the child displays unusual or fearful responses to parents/carers or older children. A pattern of ongoing neglect should also be considered even when there are short periods of improvement.

\section{Stage 2: Looking out for signs of neglect or abuse}

2.7.3 Signs of neglect or abuse can be physical, behavioural or developmental. They can exist in the relationships between children and parents/carers or between children and other family members/other persons. A cluster or pattern of signs is more likely to be indicative of neglect or abuse. Children who are being abused may hint that they are being harmed and sometimes make direct disclosures. Disclosures should always be taken very seriously and should be acted upon, for example, by informing the HSE Children and Family Services. The child should not be interviewed in detail about the alleged abuse without first consulting with the HSE Children and Family Services. This may be more appropriately carried out by a social worker or An Garda Síochána. Less obvious signs could be gently explored with the child, without direct questioning. Play situations, such as drawing or story-telling, may reveal information.

2.7.4 Some signs are more indicative of abuse than others. These include:

(i) disclosure of abuse by a child or young person;

(ii) age-inappropriate or abnormal sexual play or knowledge;

(iii) specific injuries or patterns of injuries;

(iv) absconding from home or a care situation;

(v) attempted suicide; 
(vi) underage pregnancy or sexually transmitted disease;

(vii) signs in one or more categories at the same time. For example, signs of developmental delay, physical injury and behavioural signs may together indicate a pattern of abuse.

2.7.5 Many signs of abuse are non-specific and must be considered in the child's social and family context. It is important to be open to alternative explanations for physical or behavioural signs of abuse.

\section{Stage 3: Recording of information}

2.7.6 If neglect or abuse is suspected and acted upon, for example, by informing the HSE Children and Family Services, it is important to establish the grounds for concern by obtaining as much information as possible. Observations should be accurately recorded and should include dates, times, names, locations, context and any other information that may be relevant. Care should be taken as to how such information is stored and to whom it is made available.

\subsection{Children with additional vulnerabilities}

2.8.1 Certain children are more vulnerable to abuse than others. Such children include those with disabilities, children who are homeless and those who, for one reason or another, are separated from their parents or other family members and who depend on others for their care and protection. The same categories of abuse - neglect, emotional abuse, physical abuse and sexual abuse - are applicable, but may take a slightly different form. For example, abuse may take the form of deprivation of basic rights, harsh disciplinary regimes or the inappropriate use of medications or physical restraints (see also Chapter 8).

\subsection{Fatal child abuse}

2.9.1 In the tragic circumstances where a child dies as a result of abuse or neglect, there are four important aspects to be considered: criminal, child protection, bereavement and notification.

2.9.2 Criminal aspects: This is the responsibility of An Garda Síochána and they must be notified immediately. The Coroner must also be notified and his or her instructions complied with in relation to post-mortems and other relevant matters.

2.9.3 Child protection aspects: These will be particularly relevant if there are other children in the family/ in the same situation, and will therefore require immediate intervention by the HSE Children and Family Services to assess risk.

2.9.4 Bereavement aspects: The bereavement needs of the family must be respected and provided for and all family members should be given an opportunity to grieve and say goodbye to the deceased child.

2.9.5 Notification aspects: The HSE should notify the death of a child to the National Review Panel and to the Health Information and Quality Authority in accordance with the HIQA's Guidance for the Health Service Executive for the Review of Serious Incidents, including deaths of children in care (HIQA, 2010):

- all deaths of children in care, including natural causes;

- all deaths of children known to the child protection system;

- serious incidents involving a child in care or known to the child protection services.

Managers and staff should cooperate fully with any review undertaken to establish the facts of the case and any actions that should be taken, to identify learning that will improve services in the future and to provide assurance to the public (see Chapter 5, Section 5.20). 


\subsection{Points to remember}

2.10.1 The severity of a sign does not necessarily equate with the severity of the abuse. Severe and potentially fatal injuries are not always visible. Neglect and emotional and/or psychological abuse tend to be cumulative and effects may only be observable in the longer term. Explanations that are inconsistent with the signs should constitute a cause for concern.

2.10.2 Neglect is as potentially fatal as physical abuse. It can cause delayed physical, psychological and emotional development, chronic ill-health and significant long-term damage. It may place children at serious risk of harm. It may also precede, or co-exist with, other forms of abuse and must be acted upon.

2.10.3 Experiencing recurring low-level abuse may cause serious and long-term harm. Cumulative harm refers to the effects of multiple adverse circumstances and events in a child's life. The unremitting daily impact of these circumstances on the child can be profound and exponential, and diminish a child's sense of safety and well-being.

2.10.4 Child abuse is not restricted to any socio-economic group, gender or culture. All signs must be considered in the wider social and family context. Serious deficits in child safety and welfare transcend cultural, social and ethnic norms, and must elicit a response.

2.10.5 Challenging behaviour by a child or young person should not render them liable to abuse. Children in certain circumstances may present management problems. This should not leave them vulnerable to harsh disciplinary measures or neglect of care.

2.10.6 Exposure to domestic violence is detrimental to children's physical, emotional and psychological well-being. The adverse effects of domestic violence have been well established.

2.10.7 While the impact of neglect is most profound on young children, it also adversely affects adolescents. Neglect renders young people liable to risk-taking behaviors, such as running away, early school leaving, anti-social behavior, mental health and addiction problems, including the risk of suicide.

2.10.8 It is sometimes difficult to distinguish between indicators of child abuse and other adversities suffered by children and families. Deprivation, stress, addiction or mental health problems should not be used as a justification for omissions of care or commissions of harm by parents/carers. The child's welfare must be the primary consideration.

2.10.9 Neglectful families may be difficult to engage. Research shows that families may be reluctant to seek help in response to experiencing the factors associated with neglect.

2.10.10 Families where neglect and abuse are prevalent may go to considerable lengths to deceive professionals. It is important for professionals to approach cases with a wary trustfulness, seek evidence to substantiate claims of improvement and speak with the children concerned individually.

2.10.11 Social workers need good observation and analytical skills in order to be able to understand the nature of the relationship between a parent and child, to understand signs of non-compliance, to work alongside a family and to come to safe and evidence-based judgements about the best course of action.

2.10.12 Working in the area of child abuse and neglect is dealing with uncertainty. Social workers and other professionals should adopt a 'respectful uncertainty' on parental reporting of improvement until supported by clear evidence. 


\section{Basis for reporting concerns and Standard Reporting Procedure}

\subsection{Purpose}

3.1.1 This chapter offers guidance to the general public and to all people, both professional and voluntary, working with or in direct contact with children who may be concerned or who suspect that children are being abused or neglected or at risk of abuse or neglect. It outlines the standard reporting procedure to be used in passing information to the statutory authorities about child protection concerns.

\subsection{Responsibility to report child abuse or neglect}

3.2.1 Everyone must be alert to the possibility that children with whom they are in contact may be suffering from abuse or neglect. This responsibility is particularly relevant for professionals such as teachers, child care workers, health professionals and those working with adults with serious parenting difficulties. It is also an important responsibility for staff and people involved in sports clubs, community activities, youth clubs, religious/faith sector and other organisations catering for children.

3.2.2 The HSE Children and Family Services should always be informed when a person has reasonable grounds for concern that a child may have been, is being or is at risk of being abused or neglected.

3.2.3 Child protection concerns should be supported by evidence that indicates the possibility of abuse or neglect.

3.2.4 A concern about a potential risk to children posed by a specific person, even if the children are unidentifiable, should also be communicated to the HSE Children and Family Services.

3.2.5 The guiding principles in regard to reporting child abuse or neglect may be summarised as follows:

(i) the safety and well-being of the child must take priority;

(ii) reports should be made without delay to the HSE Children and Family Services.

3.2.6 Any reasonable concern or suspicion of abuse or neglect must elicit a response. Ignoring the signals or failing to intervene may result in ongoing or further harm to the child.

3.2.7 Section 176 of the Criminal Justice Act 2006 introduced the criminal charge of reckless endangerment of children. It states:

'A person, having authority or control over a child or abuser, who intentionally or recklessly endangers a child by -

(a) causing or permitting any child to be placed or left in a situation which creates a substantial risk to the child of being a victim of serious harm or sexual abuse, or

(b) failing to take reasonable steps to protect a child from such a risk while knowing that the child is in such a situation,

is guilty of an offence!

The penalty for a person found guilty of this offence is a fine (no upper limit) and/or imprisonment for a term not exceeding 10 years.

3.2.8 The HSE has a statutory obligation to identify children who are not receiving adequate care and protection, to provide family support services and, where necessary, to take children into the care of the HSE. People who report concerns need to be assured that their information will be carefully considered with any other information available, and a child protection assessment will only proceed where sufficient risk is identified. 
3.2.9 Any professional who suspects child abuse or neglect should inform the parents/carers if a report is to be submitted to the HSE Children and Family Services or to An Garda Síochána, unless doing so is likely to endanger the child.

3.2.10 The HSE will respect the wishes of non-professionals reporting concerns in good faith who ask to remain anonymous in as much as possible, but cannot give a guarantee that the information would not be sought and given within judicial proceedings. (The Data Protection Acts offer protection under privacy, but should the information be sought directly within legal proceedings, there is no guarantee.)

\subsection{Designated Liaison Persons for reporting neglect or abuse}

3.3.1 Every organisation, both public and private, that is providing services for children or that is in regular direct contact with children should:

(i) Identify a designated liaison person to act as a liaison with outside agencies and a resource person to any staff member or volunteer who has child protection concerns.

(ii) The designated liaison person is responsible for ensuring that the standard reporting procedure is followed, so that suspected cases of child neglect or abuse are referred promptly to the designated person in the HSE Children and Family Services or in the event of an emergency and the unavailability of the HSE, to An Garda Síochána.

(iii) The designated liaison person should ensure that they are knowledgeable about child protection and undertake any training considered necessary to keep themselves updated on new developments.

\subsection{Standard Reporting Procedure}

3.4.1 Any person reporting a child abuse or neglect concern should do so without delay to the HSE Children and Family Services. A report can be made in person, by telephone or in writing. Contact numbers for all HSE offices nationwide are given in Appendix 2 of this national guidance and are also available on the HSE website (www.hse.ie) or through the HSE LoCall Tel. 1850241850.

3.4.2 Before deciding whether or not to make a formal report, you may wish to discuss your concerns with a health professional or directly with the HSE Children and Family Services (see HSE contacts in Appendix 2).

3.4.3 Under no circumstances should a child be left in a situation that exposes him or her to harm or to risk of harm pending HSE intervention. In the event of an emergency where you think a child is in immediate danger and you cannot get in contact with the HSE, you should contact the Gardaí. This may be done through any Garda station.

3.4.4 The Standard Report Form for reporting child welfare and protection concerns to the HSE (see Appendix 3) should be used by professionals, staff and volunteers in organisations working with or in contact with children, or providing services to children when reporting child protection and welfare concerns to the HSE Children and Family Services. If a report is made by telephone, this form should be completed and forwarded subsequently to the HSE.

3.4.5 The HSE will follow up on all referrals, even if the Standard Report Form has not been used.

\subsection{Information to be included when making a report}

3.5.1 The ability of the HSE Children and Family Services or An Garda Síochána to assess and investigate suspicions or allegations of child abuse or neglect will depend on the amount and quality of information conveyed to them by the people reporting concerns. As much as possible of the following detail should be provided: 
(i) the name, address and age of the child (or children) for whom the report is being made;

(ii) the name of the child's school;

(iii) the name and contact details of the person reporting concerns;

(iv) whether the person reporting is a professional, a person working with children or a member of the public;

(v) the relationship to the child of the person making the report;

(vi) a full account of what constitutes the grounds for concern in relation to the protection and welfare of the child or children, e.g. details of the allegation, incident, dates, description of any injuries, etc;

(vii) the names and addresses of the parents/carers of the child or children;

(viii) the names of other children in the household;

(ix) the name, address and details of the person allegedly causing concern in relation to the child or children;

(x) the child's and/or parents/carers' own views, if known and relevant;

(xi) the names and addresses of other personnel or agencies involved with the child or children, e.g. GP, social worker, public health nurse, Gardaí, etc;

(xii) any other relevant information.

\subsection{Retrospective disclosures by adults}

3.6.1 An increasing number of adults are disclosing abuse that took place during their childhoods. Such disclosures often come to light when adults attend counselling. It is essential to establish whether there is any current risk to any child who may be in contact with the alleged abuser revealed in such disclosures.

3.6.2 If any risk is deemed to exist to a child who may be in contact with an alleged abuser, the counsellor/ health professional should report the allegation to the HSE Children and Family Services without delay.

3.6.3 The HSE National Counselling Service is in place to listen to, value and understand those who have been abused in childhood. The service is a professional, confidential counselling and psychotherapy service and is available free of charge in all regions of the country (see www.hse-ncs.ie/en). The service can be accessed either through healthcare professionals or by way of self-referral (Freephone 1800 477477).

\subsection{Deciding to share child protection concerns}

3.7.1 The belief that parents/carers or other persons in charge of children would actually harm or neglect them is not easy to sustain. There may be a tendency, therefore, to deny, minimise or explain away any signs that a child is being harmed, even when evidence exists. At times, it is hard to distinguish between abusive situations and those where other problems are present, such as unemployment, poverty, poor housing, addiction, mental illness or isolation. Sympathy for families in difficult circumstances can sometimes dilute personal or professional concerns about the safety and welfare of children. However, the protection and welfare of the child must always be the paramount concern. 
3.7.2 Reluctance to act on suspicions about child abuse or neglect can often stem from uncertainty and fear. Members of the public or professionals may be afraid of repercussions, afraid of being thought insensitive, afraid of breaking a confidence or afraid of being disloyal. Knowledge and information about child abuse will help to overcome reluctance to take action. So too will confidence in the child protection and welfare services.

3.7.3 It is the responsibility of all agencies working with children and for the public to recognise child protection concerns and share these with the agencies responsible for assessing or investigating them, not to determine whether the child protection concerns are evidenced or not.

\subsection{Cases not reported to the HSE or An Garda Siochána}

3.8.1 In those cases where an organisation decides not to report concerns to the HSE or An Garda Síochána, the individual employee or volunteer who raised the concern should be given a clear written statement of the reasons why the organisation is not taking such action. The employee or volunteer should be advised that if they remain concerned about the situation, they are free as individuals to consult with, or report to, the HSE or An Garda Síochána. The provisions of the Protections for Persons Reporting Child Abuse Act 1998 apply once they communicate 'reasonably and in good faith' (see Paragraph 3.10.1).

\subsection{Confidentiality}

3.9.1 The effective protection of a child often depends on the willingness of the staff in statutory and voluntary organisations involved with children to share and exchange relevant information. It is therefore critical that there is a clear understanding of professional and legal responsibilities with regard to confidentiality and the exchange of information.

3.9.2 All information regarding concern or assessment of child abuse or neglect should be shared on 'a need to know' basis in the interests of the child with the relevant statutory authorities.

3.9.3 No undertakings regarding secrecy can be given. Those working with a child and family should make this clear to all parties involved, although they can be assured that all information will be handled taking full account of legal requirements.

3.9.4 Ethical and statutory codes concerned with confidentiality and data protection provide general guidance. They are not intended to limit or prevent the exchange of information between different professional staff with a responsibility for ensuring the protection and welfare of children. The provision of information

\section{to the statutory agencies for the protection of a child is not a breach of confidentiality or data protection.}

3.9.5 It must be clearly understood that information gathered for one purpose must not be used for another without consulting the person who provided that information.

3.9.6 The issue of confidentiality should be part of the training necessary for staff who work in the area of child protection and welfare and the general training of staff in organisations that work with children. Each organisation should have a written policy in this regard.

\subsection{Legal protection}

3.10.1 The Protections for Persons Reporting Child Abuse Act $\mathbf{1 9 9 8}$ makes provision for the protection from civil liability of persons who have communicated child abuse 'reasonably and in good faith' to designated officers of the HSE (see Appendix 10) or to any member of An Garda Síochána. This protection applies to organisations as well as to individuals. This means that even if a communicated suspicion of child abuse proves unfounded, a plaintiff who took an action would have to prove that the person who communicated the concern had not acted reasonably and in good faith in making the report. 
3.10.2 A person who makes a report in good faith and in the child's best interests may also be protected under common law by the defence of qualified privilege.

\subsection{Freedom of information}

3.11.1 Notwithstanding the requirement of all professionals involved in child protection and welfare cases to share relevant information, records are nevertheless confidential. They do not belong to individuals (except for independent practitioners) and are the property of the organisations that keep them. Under the Freedom of Information Acts 1997 and 2003, members of the public have a right of access to records concerning them held by any public body and a right to have official information about themselves amended where it is incorrect, incomplete or misleading. Members of the public also have a right to be given reasons for decisions made concerning themselves. Requests to see records are processed in the first instance through the public body that holds the records. In the event of refusal of access, the decision may be appealed and the ultimate arbiter is the Information Commissioner. At present, these Acts apply to the HSE, but not to An Garda Síochána.

3.11.2 The Data Protection Acts $\mathbf{1 9 8 8}$ and $\mathbf{2 0 0 3}$ afford similar rights to individuals to access personal data held about them by any entity whether in the public or private sector. The right to access applies to records held by the HSE and An Garda Síochána. However, the right to access does not apply in a range of circumstances that may be relevant in a child welfare context. Equally, the right of access does not extend to any information that identifies a third party where that third party had an expectation of confidence. Accordingly, it would not be necessary to provide any information that would identify a person making a child welfare report in response to a request under the Data Protection Acts.

3.11.3 A full list of the relevant legislation concerning child protection and welfare is provided in Appendix 7 of this national guidance. 


\section{Interagency Cooperation: Roles and responsibilities of organisations and personnel working with children}

\subsection{Purpose}

4.1.1 No one professional has all the skills, knowledge or resources necessary to comprehensively meet all the requirements of an individual case. It is essential, therefore, that all professionals and organisations involved with a child and his or her parents/carers deliver a coordinated response. This chapter identifies the roles and responsibilities of Central Government, the HSE, An Garda Síochána and other organisations working with children. It also outlines the benefits of effective interagency cooperation.

\subsection{Roles and responsibilities of Central Government}

4.2.1 Central Government and its agencies, notably the HSE, share responsibility for promoting the welfare and safety of children, and should ensure that services reach the high standards that are required to protect and support children. Central Government, through the Department of Children and Youth Affairs, has responsibility for developing the legislative and policy framework through which the child protection and welfare services are delivered, monitored, inspected and measured. The Department of Children and Youth Affairs will keep under review the effectiveness of the Children First: National Guidance.

4.2.2 Every Government department or publicly funded body that delivers or funds services to children whether directly or indirectly through bodies or agencies under its aegis - has a responsibility to ensure that there is an awareness within the relevant organisations of the Children First: National Guidance and that the standards in relation to child protection and welfare set out in the guidance are adhered to in the delivery of those services. This includes, in particular, the effective communication of roles and responsibilities under the national guidance.

\subsection{Benefits of interagency cooperation and exchange of information in relation to child protection and welfare}

4.3.1 Effective interagency cooperation has a number of benefits, including:

(i) ensuring provision of a comprehensive response to all concerns about children. This includes the pooling of resources and skills at all stages of intervention, from initial enquiry to assessment and case management, including early identification and prevention;

(ii) avoiding gaps in the service response, especially in cases where information might otherwise remain concealed or unknown;

(iii) providing mutual support for professionals in complex cases.

4.3.2 The effectiveness and usefulness of interagency and interprofessional cooperation and coordination is influenced by certain conditions that should be addressed specifically in training programmes. These conditions include:

(i) dissemination on a regular basis of procedures, guidelines and policies;

(ii) clear contractual arrangements between statutory and non-statutory bodies;

(iii) an understanding and acceptance by all professionals working with children of their responsibilities and roles in the promotion of child welfare;

(iv) mutual trust in the sharing of information; 
(v) agreement on common goals with regard to a child's safety and welfare;

(vi) willingness of professionals to respect the contributions made by each other, irrespective of status and position within agencies and organisations;

(vii) awareness of the potential for interprofessional tensions, defensiveness, prejudices, rivalries and polarity of views, which may, from time to time, prevent the needs of children from taking precedence.

4.3.3 Training to promote interagency and interprofessional cooperation and coordination should include front-line personnel who meet or talk with the public (e.g. telephonists and receptionists), who are frequently the recipients of urgent information and have an essential role to play in communication (see also Chapter 10, Paragraph 10.5.6).

4.3.4 Interagency cooperation is as important in the later stages of child protection work as it is at the outset. All personnel involved in a case should consistently make efforts to remain in contact with the key worker (who is normally the HSE social worker) and to communicate any relevant information.

4.3.5 Interagency and interprofessional cooperation and coordination should never become an end in itself. The child's safety and protection must take precedence at all times. Collusion must be avoided.

\section{Partnership working - Exchange of information}

4.3.6 Arrangements for child protection and welfare can only be successful if staff in the statutory and non-statutory organisations concerned work in partnership and share relevant information, in particular with the HSE Children and Family Services and An Garda Síochána.

\subsection{Roles and responsibilities of the HSE Children and Family Services}

4.4.1 Under the Child Care Act 1991, the HSE has certain statutory obligations for the protection and welfare of children:

(i) the HSE must be open to receiving information from any source about a child who may not be receiving adequate care and protection;

(ii) having received such information, the HSE must seek to establish whether the child in question is receiving adequate care and protection. To this end, it must coordinate information from all relevant sources and make an assessment of the situation;

(iii) having identified a child who is not receiving adequate care and protection, the HSE is under a duty to take appropriate action to promote the welfare of the child.

4.4.2 The HSE has responsibility for operating a child protection and welfare service, putting in place and promoting written procedures and practice guidance, and providing leadership and commitment to interagency cooperation and training. The HSE also has responsibility for:

(i) regularly reviewing all policies and procedures for joint working;

(ii) resourcing child protection services in line with policies;

(iii) operating within clear management structures, providing training and supervision for all staff undertaking child protection and welfare work;

(iv) developing and maintaining effective information systems;

(v) developing and maintaining standards and operating a quality control system;

(vi) developing procedures that enable parents/carers, children and others to make representations, including complaints; 
(vii) publishing advice for the general public, professionals and anyone caring for a child, clearly indicating who should be contacted if they have concerns about a child being harmed or at risk of being harmed;

(viii) developing procedures to safeguard information and ensure timely transfer of records when a child about whom there is a child protection concern or a family moves from one HSE area to another or from one jurisdiction to another. The procedure should state that, prior to the transfer of information to another jurisdiction, there is either consent, a legal basis or a serious child protection concern.

4.4.3 Every HSE Local Health Office area has a designated person within the HSE with responsibility for coordinating child protection services. These personnel are responsible for:

(i) receiving all notifications of child abuse (see Chapter 5);

(ii) taking decisions relating to the holding of child protection conferences;

(iii) promoting interagency cooperation on child protection and welfare;

(iv) promoting interprofessional and interprogramme cooperation on child protection and welfare;

(v) overseeing staff training programmes;

(vi) negotiating service agreements with non-statutory service providers.

4.4.4 An effective child protection and welfare environment requires close working relationships and interagency and interprofessional cooperation. This, in turn, requires cooperation at national, regional and local level by the key stakeholders.

4.4.5 In the interests of the continuous improvement of services, the HSE may redesign its structures and business processes in relation to the child protection and welfare system. This may include the redesign of procedures (such as standardised forms) and the revision of terminology. Any such changes must be consistent with national policy direction as articulated in the current Children First: National Guidance, must be implemented consistently across the HSE and must be clearly communicated to all relevant staff, service users and other agencies.

\subsection{Roles and responsibilities of An Garda Siochána}

4.5.1 The involvement of An Garda Síochána in cases of alleged child abuse and neglect stems from its primary responsibility to protect the community and to bring offenders to justice. Where it is suspected that a crime has been committed, An Garda Síochána has overall responsibility for the direction of any criminal investigation. It is the function of An Garda Síochána to interview and take any statements that will form part of the criminal investigation file.

4.5.2 The role of An Garda Síochána is to investigate and it is the responsibility of the Director of Public Prosecutions (DPP) to decide on, and to carry out, prosecution.

\section{Garda Central Vetting Unit}

4.5.3 The Garda Central Vetting Unit (GCVU) provides vetting on behalf of organisations employing personnel to work in a full-time, part-time, voluntary or student placement capacity with children and/or vulnerable adults. The GCVU provides its vetting service for each sector requiring vetting through a sectoral 'central point of contact', the task of which is to process vetting applications centrally for that sector. The Authorised Signatory is the point of contact appointed in each organisation to forward forms to the GCVU and any disclosures from Gardai are returned to the Authorised Signatory confidentially, the implications of which can be assessed by prospective employers using a risk management approach. The GCVU does not deal with individual requests for vetting. An individual must make a written application through the organisation to which their area of work is affiliated. 
4.5.4 Garda vetting is part of good recruitment practice. While Garda vetting is currently not statutory, it is intended to place it on a statutory basis. The GCVU does not decide on the suitability of any person to work with children and vulnerable adults. Rather, in response to a written request for vetting, the GCVU releases criminal history information on the person to be vetted to the prospective recruiting organisation. Decisions on suitability for recruitment rest at all times with the recruiting organisation and the results of vetting should form only one component of the recruitment decision.

4.5.5 Employers/heads of organisations where staff or volunteers have access to children should at all times implement safe recruitment practices, including vetting of applicants and staff, rigorous checking of references, interview procedures and monitoring of good professional practice.

\subsection{Cooperation between An Garda Siochána and the HSE Children and Family Services}

4.6.1 An Garda Síochána and the HSE Children and Family Services have different functions, powers and methods of working. The specific focus of the HSE is on the assessment of the welfare of the child and family. The specific focus of An Garda Síochána is on the investigation of alleged offences and whether a crime has been committed. Joint working between the HSE Children and Family Services and An Garda Síochána forms an integral part of the child protection and welfare service and is described in more detail in Chapter 7.

\subsection{Roles and responsibilities of Other Statutory Agencies and Non-statutory Organisations}

4.7.1 There are many organisations providing services to, working with and in direct contact with children. Some are statutory, some are non-statutory and/or not-for-profit organisations, while others are private forprofit organisations. All organisations involved with children have an obligation to provide them with the highest possible standard of care in order to promote their well-being and safeguard them from abuse. Organisations may also be legally responsible for their failure to provide adequate care and safeguards for children in their care.

4.7.2 All statutory, voluntary and community organisations working with and in direct contact with children should have procedures and guidelines derived from and consistent with the current Children First: National Guidance for their staff and volunteers. The content of such local guidelines should not be at variance with the national guidance, but there may be particular specificity or elaboration appropriate to local circumstances (see Appendix 8 for guidance on developing local child protection procedures). Voluntary and community organisations, for example, will need to outline specific procedures for personnel on how to respond to concerns or suspicions of child abuse. Where these organisations have adapted the national guidance to local guidelines and wish to have them reviewed for their efficacy, the HSE Children and Family Services will facilitate this. Completed local guidelines should be forwarded to the HSE as a matter of good practice.

4.7.3 Our Duty to Care: The principles of good practice for the protection of children and young people, published in 2002, offers specific guidance to the community and voluntary sectors on the promotion of child protection and welfare practices. The document includes information on the correct steps to be taken if child abuse is suspected, witnessed or disclosed. It also contains information on developing safe recruitment procedures and policies. It should be read in conjunction with the national guidance.

4.7.4 The HSE employs Children First Information and Advice Officers who are available to liaise with voluntary and community organisations and provide advice on child protection issues. Voluntary and community organisations should also be included in relevant training courses. 
4.7.5 All organisations in contact with or providing services to children have an overall corporate duty and responsibility to safeguard children by the following means:

(i) promoting the general welfare, health, development and safety of children;

(ii) adopting and consistently applying a safe and clearly defined method of recruiting and selecting staff and volunteers;

(iii) developing guidance and procedures for staff and volunteers who may have reasonable grounds for concern about the safety and welfare of children involved with the organisation. These procedures should not deviate from the current Children First: National Guidance, but could offer further elaboration to ensure local relevance and applicability. It is the responsibility of each organisation's Board of Directors or Management to ensure that such policies and procedures are in place and are operating effectively (see Appendix 8 for guidance on developing local child protection procedures);

(iv) identifying a designated liaison person to act as a liaison with outside agencies and a resource person to any staff member or volunteer who has child protection and welfare concerns. The designated liaison person is responsible for reporting allegations or concerns of child abuse to the HSE Children and Family Services or to An Garda Síochána;

(v) ensuring that the organisation has clear written procedures on the action to be taken if allegations of abuse against employees/volunteers are received (see Appendix 9 on guidance for employers dealing with an allegation of abuse);

(vi) raising awareness within the organisation about potential risks to children's safety and welfare;

(vii) developing effective procedures for responding to accidents and complaints;

(viii) ensuring that clear procedures in relation to record-keeping of child protection and welfare concerns are in place and are operating effectively, taking appropriate account of the need to ensure that such records are kept securely. Organisations that administer services through a number of individual units should standardise recording procedures in cases of children at risk. All agencies dealing with children must have a policy of cooperating with the HSE Children and Family Services on the sharing of their records where a child welfare or protection issue arises.

\subsection{Roles and responsibilities of Schools}

4.8.1 School authorities have primary responsibility for the care and welfare of their pupils. The Department of Education and Skills is responsible for developing and implementing child protection procedures for schools based on the Children First: National Guidance. The aim of such procedures is to give direction to school management and staff regarding the identification of and response to child protection concerns and the continued support of the child. It is the responsibility of the Department of Education and Skills to inspect and evaluate the implementation of these procedures for education staff.

\section{Responsibilities of school management}

4.8.2 It is the responsibility of the Board of Management of each school:

(i) to have clear procedures, which teachers and other school staff must follow where they suspect, or are alerted to, possible child abuse or neglect, including where a child discloses abuse or neglect;

(ii) to designate a senior member of staff to have specific responsibility for child protection (see Chapter 3 , Section 3.3 for role of designated liaison persons). In larger schools, it may be necessary that the role be designated to other staff to ensure timely sharing of concerns, in which case organisational accountability must be kept; 
(iii) to monitor the progress of children considered to be at risk;

(iv) to contribute to the prevention of child abuse or neglect through curricular provision;

(v) to provide or access in-service training for teachers and members of the Board of Management to ensure that they have a good working knowledge of child protection issues and procedures;

(vi) to have clear written procedures in place concerning action to be taken where allegations are received against school employees.

4.8.3 Teachers are particularly well placed to observe and monitor children for signs of abuse and neglect. They are the main care-givers to children outside the family context and have regular contact with children in the school setting.

4.8.4 Teachers have a general duty of care to ensure that arrangements are in place to protect children and young people from harm. In this regard, children need to be facilitated to develop their self-esteem, confidence, independence of thought and the necessary skills to cope with possible threats to their personal safety, both within and outside the school. Management arrangements within primary and post-primary schools should provide for the following:

(i) the planning, development and implementation of an effective child protection programme;

(ii) continuous monitoring and evaluation of the effectiveness of such a programme;

(iii) the effective implementation of agreed reporting procedures;

(iv) the planning and implementation of appropriate staff development and training programmes.

\section{Responsibilities of school staff}

4.8.5 If a child discloses to a teacher or to other school staff that he or she is being harmed by a parent/carer or any other person, including another child, the person who receives that information should listen carefully and supportively. This applies equally where the child implies that he or she is at risk of being harmed by a parent/carer or any other person. It also applies equally if a parent/carer or any other person discloses that he or she has harmed, or is at risk of harming, a child. The child should not be interviewed formally; the teacher or other staff member should obtain only necessary relevant facts if and when clarification is needed. Confidentiality must never be promised to a person making a disclosure subject to the provisions of the Data Protection Acts and the requirement to report to the HSE Children and Family Services must be explained in a supportive manner. The discussion should be recorded accurately and the record retained securely. The teacher or other staff member should then inform the designated liaison person who is responsible for reporting the matter to the HSE Children and Family Services, or in the event of an emergency and the unavailability of the HSE, to An Garda Síochána.

\section{ROLES AND RESPONSIBILITIES OF THE HEALTH SECTOR}

\subsection{Roles and responsibilities of General Practitioners and Primary Care Teams}

4.9.1 General practitioners (GPs) and Primary Care Teams are in a good position to identify indications of abuse and neglect or signs of family stress that may point, at an early stage, to a risk of child abuse. GPs may have certain knowledge of the family backgrounds of their patients, which may enable them to make a particular contribution to abuse prevention, child protection and the long-term support of the child and family.

4.9.2 Primary Care Teams and GP practice staff should receive appropriate training in the recognition of child abuse and in the operation of local procedures. They should have clearly defined professional support and clinical supervision. 
4.9.3 While GPs have responsibilities to all their patients, their primary consideration should be the best interests of the child. Whenever a GP becomes concerned that a child may be at risk of, or the subject of, abuse of any kind, it is essential that these concerns are discussed with the HSE Children and Family Services without delay.

4.9.4 Where clinical uncertainty exists, GPs may need to discuss their concerns with other professionals who are experienced in working with child abuse cases. GPs should therefore be aware of how to contact the relevant personnel for expert medical advice. Where, following such discussion, a GP is satisfied that there are reasonable grounds for suspecting that a child is being, or has been, abused or neglected, he or she should immediately inform the HSE Children and Family Services in accordance with the standard reporting procedure (see Chapter 3).

\subsection{Roles and responsibilities of Hospitals}

4.10.1 Like GPs and Primary Care Teams, hospital staff are also in a pivotal position to identify cases where reasonable grounds for concern exist regarding the protection and welfare of children and to participate in the assessment of those concerns. Coordinated working arrangements should be established between hospitals and the HSE Children and Family Services for the identification of child abuse and for further interventions.

4.10.2 Concerns by hospital staff should be reported to line management. Hospital management should act in a protective and preventive manner by referring any concerns to the appropriate agencies in respect of children and families who are in need of support services.

4.10.3 All front-line staff, particularly in emergency departments, must be alert to indicators of actual or potential child abuse or neglect. Standardised record systems should be adopted by hospitals in order to highlight repeated visits by children presenting with injuries. Concerns noted by any staff member should be reported to line management. A multidisciplinary approach is essential. Medical and social histories should be obtained and accurately recorded, covering the following areas:

(i) circumstances of the child's presentation to hospital;

(ii) details of injuries or other signs of neglect;

(iii) explanations offered by parents/carers and/or child;

(iv) general demeanour of parents/carers and/or child;

(v) family history;

(vi) whereabouts and safety of other siblings or children in the same situation;

(vii) whether or not the child should be admitted in order to guarantee safety.

4.10.4 It is essential that an open and honest approach is taken with parents/carers, who must be given full information about the concerns that exist, the need for any further medical or social assessments, and the intention of the hospital staff to report the concern to the HSE Children and Family Services.

4.10.5 The child must be kept appropriately informed of developments and should be allowed an opportunity to offer his or her view, taking into account level of maturity and stage of development. Contact between parents/carers and children should be facilitated, unless it is considered that the child would be endangered by so doing. The child's need for emotional support from parents/carers must be carefully balanced against concerns for his or her safety. 


\section{Medical examinations}

4.10.6 The cooperation of parents/carers should be sought for any examinations and assessment considered necessary. If cooperation is not forthcoming, the possibility of legal action should be considered and conveyed to parents/carers (see Chapter 5, Paragraph 5.18.3).

\section{Fatal child abuse}

4.10.7 Where a child has died as a result of suspected or confirmed child abuse, the following actions must be taken by hospital authorities:

(i) An Garda Síochána and the HSE Children and Family Services must be notified immediately;

(ii) the Coroner must be notified;

(iii) the protection of other children in the family must be urgently considered;

(iv) the bereavement needs of the family must be addressed with sensitivity.

\subsection{Roles and responsibilities of Mental Health and Addiction Services}

4.11.1 Professionals who are treating a person with a mental health or addiction problem must consider the welfare and safety of any children in that person's family and/or children in regular contact with the person. Where there are concerns, these must be discussed and reported to the HSE Children and Family Services, as outlined in the standard reporting procedure (see Chapter 3 ).

4.11.2 Professionals in the adult mental health and addiction services may find themselves assessing people who have a history of abusing or neglecting children. In such cases, the potential risk to any child with whom this person may have contact must be considered and communicated to the HSE Children and Family Services and to any other service involved in providing treatment or other assistance to the family.

4.11.3 Where work with a family involves both the victim and the perpetrator of abuse, it is essential that efforts are coordinated and that information is shared between professionals. The child's needs must remain paramount. All decisions taken in relation to parents/carers with a mental health or addiction problem of relevance to the child's protection and welfare, such as a discharge back to their family or termination of treatment, must be communicated to the relevant HSE personnel.

\subsection{Roles and responsibilities of Child and Adolescent Psychiatry Services}

4.12.1 Child and adolescent psychiatric services often work with families over a long period and are particularly well placed to identify child protection concerns. It is the responsibility of staff in the child and adolescent psychiatric services to establish as far as possible the grounds for any child protection concern that may exist and to report this to the HSE Children and Family Services.

4.12.2 The HSE holds overall responsibility for the child protection aspects of a case. Non-HSE mental health services must operate child protection procedures in line with those of the HSE. It is essential that they coordinate their work with the HSE in a manner that facilitates joint working as far as possible between the two services in order to maximise the possibility of protecting any children involved. It is essential that information relevant to children's safety and protection is communicated between the two services at all stages of work. 


\subsection{Roles and responsibilities of Private Healthcare Providers and Non-statutory Providers of services to children}

4.13.1 Professionals who see children and families on a private basis, or non-statutory providers of services to children, must also follow child protection guidance. It is the responsibility of the designated person within the HSE to ensure that, as far as possible, all private practitioners and non-statutory providers receive copies of procedures for communicating concerns to the HSE Children and Family Services.

\subsection{Roles and responsibilities of Other Health Professionals}

4.14.1 Other health professionals are major contributors to child protection and welfare. They promote the welfare of children through health promotion and health surveillance programmes. They are well placed to identify and refer child protection concerns, participate in assessment, attend child protection conferences and work with the HSE Children and Family Services in planning the ongoing support of the child and family.

\subsection{Roles and responsibilities of Other Statutory Organisations}

\section{Health Information and Quality Authority and the Social Services Inspectorate}

4.15.1 The Health Information and Quality Authority (HIQA) is an independent authority, established to drive continuous improvement in Ireland's health and social care services. The HIQA is responsible for the development of quality standards for child protection and welfare services, and in measuring performance against those standards. The Social Services Inspectorate (SSI) within the HIQA has responsibility for inspecting services for children in care and in detention schools.

\section{National Educational Welfare Board}

4.15.2 The National Educational Welfare Board (NEWB) has a statutory function to ensure that every child either attends a school or otherwise receives an education. The NEWB must also maintain a register of all children in receipt of an education in a place other than a recognised school, such as children who are educated at home. The NEWB has a responsibility to follow up on children who are out of school, have no school place or are not attending school regularly, and where there is a concern about the child's educational welfare. Educational Welfare Officers (EWOs) deliver a service directly to children, families and schools to ensure that each child attends and benefits from education. They focus on identifying the causes of the problems behind a child or young person not attending school and work with other services to overcome the barriers to school attendance. EWOs are well placed to identify children with additional needs and vulnerabilities. Any type of abuse will affect a child's educational welfare prospects and it is the duty of the NEWB to report when any abuse is suspected or evident. A protocol between the NEWB and the HSE Social Work Service will identify the main opportunities and obligations on staff in the two agencies to communicate and work together in relation to vulnerable children.

\section{Ombudsman for Children}

4.15.3 The Office of the Ombudsman for Children is an independent office, accountable to the Oireachtas, with statutory duties to promote and safeguard the rights and welfare of children. Its main functions are:

- to provide an independent complaints-handling service regarding public bodies;

- to initiate investigations under own motion to examine whether there are systemic problems that may give rise to difficulties for many children;

- to promote children's rights, including through participation and communications activities;

- to monitor and review legislation on matters relating to the rights and welfare of children;

- to advise any Government Minister on any matter relating to the rights and welfare of children;

- to ensure that law, policy and practice meet the highest standards and obligations in accordance with the UN Convention on the Rights of the Child. 


\section{The Probation Service}

4.15.4 Probation officers may become involved in cases of child abuse and neglect as a result of their statutory responsibility for the supervision of offenders, including child offenders and those convicted of offences against children. Probation officers also undertake the preparation of reports on people charged with criminal offences and the provision of welfare services for prisoners and those recently released from prison.

4.15.5 In the course of these duties, probation officers may encounter cases of child abuse or the risk of abuse. The Probation Service should ensure that procedures are in place so that any potential, suspected or actual cases of child abuse are brought to the attention of the HSE Children and Family Services. 


\title{
PART III:
}

\section{Guidance for HSE Children and Family Services and Other Professionals}

\author{
Protocol for \\ An Garda Siochána - HSE Liaison
}




\section{Assessment and Management of child protection and welfare concerns}

\section{GENERAL GUIDELINES}

\subsection{Purpose}

5.1.1 This chapter offers guidance on the steps to be taken by staff in the HSE Children and Family Services and other professionals in responding to reported child protection and welfare concerns. It describes the assessment process to be followed in order to establish whether reasonable grounds for concern exist. Guidance is offered on the effective use of child protection conferences, the development of a child protection plan and the aims and objectives of child protection review conferences.

\subsection{Referral and Assessment}

5.2.1 All child protection and welfare concerns reported to the HSE Children and Family Services must be acted upon immediately and formally recorded, and followed up as soon as possible.

5.2.2 Reported concerns about child protection and welfare are normally followed up by a HSE social worker. However, the HSE Social Work Manager may allocate this role to another professional or agency closely involved with the family. Alternatively, the work may be carried out jointly between the HSE and another agency. In these circumstances, the expectations held by the HSE or any non-HSE professionals or agency must be made clear. Any professional involved in following up child protection and welfare concerns must report the outcome of their enquiries without delay to the HSE Social Work Manager.

5.2.3 The HSE should operate standard assessment procedures for reported concerns about children. These procedures should cover notification to the designated person within the HSE, notification to An Garda Síochána, strategy meetings, child protection conferences, child protection review and assessment of risk to the child and any other child in the same situation (see Chapter 7 for full details).

5.2.4 Professional staff should adhere to HSE standard procedures for reported concerns about children.

5.2.5 The assessment of a child protection and welfare concern can often be complicated by factors outside the control of the professionals involved and does not always resemble the ordered process described in this national guidance. The safety and welfare of a child must remain the priority throughout and the remainder of the tasks dealt with in the most efficient and expeditious manner possible. Any difficulties in accessing information must be recorded and brought to the attention of the HSE Social Work Manager or designated person within the HSE.

5.2.6 Non-HSE agencies or professionals may have relevant information to contribute to the assessment of a child protection and welfare concern. These may include general practitioners, teachers, counsellors and other services with which the child and/or parents/carers have had contact. Information should normally only be sought from professionals working outside the HSE when the parents/carers concerned have been informed that such information will be sought. However, in circumstances where the perceived risk to the child is such that it is not deemed desirable to contact the parents/carers in the first instance, a HSE professional could justifiably request non-HSE professionals to release whatever information might enable clarification of the initial reported concern. The legal basis in the Child Care Act 1991 that allows non-HSE professionals to provide this information should be cited when making the request (see Appendix 7).

5.2.7 Assessment of child protection and welfare concerns is a continuous process and persists while the case is open to the HSE Children and Family Services. 


\subsection{Screening and Preliminary Enquiries}

5.3.1 Reports and requests for services must be screened in order to establish their appropriateness to the HSE Children and Family Services.

5.3.2 HSE records must be checked at the earliest opportunity to establish whether a child or family is known to the HSE Children and Family Services and the nature of any information available. If internal records indicate that a case is already known within the HSE, the key professionals involved should be contacted as appropriate.

5.3.3 It may be necessary to contact the relevant public health nurse, area medical officer, social worker, child care worker or other HSE colleague for information or for clarification of existing information.

5.3.4 If, on the basis of the reported concern and/or any existing information, there is reason to believe that a child has been harmed or is at risk of further harm or ongoing neglect, or that their safety and welfare are at risk, the concern must be followed up immediately and any necessary interventions made. The available information should be reviewed with HSE management and formally recorded in order to establish an appropriate level of response.

\subsection{Initial Assessment}

5.4.1 The initial assessment of concerns is usually based on limited information with the emphasis being on the nature and degree of any harm and the immediate safety of the child. The assessment should also, insofar as possible, identify whether the child's needs are being adequately met and whether there is any other help the family may need in order to care adequately for the child. The assessment should include a review of the most critical areas of risk and need, should identify family strengths and protective factors and take account of available service resources.

5.4.2 A number of key tasks are involved when the HSE carries out an assessment of a child protection and welfare concern. These include:

(i) establishing with the child and his or her parents/carers whether grounds for concern exist;

(ii) if necessary, arranging for a medical examination, assessment for child sexual abuse and medical treatment (see also Section 5.18);

(iii) communicating with any professionals involved with the child and family, and eliciting their views on the report of abuse;

(iv) identifying the nature and severity of any risks;

(v) identifying any strengths and protective factors that appear to lessen the risk, such as protective care, support of extended family member or friend, or existing family support service;

(vi) when a decision is made to offer services to a child and his or her parents/carers, the case must be allocated to a key worker, if this has not already happened;

(vii) deciding on initial protective action pending, or prior to, further action, such as further assessment, strategy meeting, child protection conference or other developmental type assessments.

5.4.3 If a reported concern has been assessed as valid and there are unresolved child protection issues, a request for a child protection conference should be made to the designated person within the HSE. In other situations, where a child welfare concern is identified, the provision of support services must be considered. In such cases, where a high level of need is identified, the HSE Children and Family Services must ensure coordination and monitoring of services by means of a family support plan (see Section 5.6). 
5.4.4 At any point during the initial assessment, it may be considered appropriate to hold a strategy meeting with all relevant professionals (see Section 5.7).

\subsection{Unfounded concerns}

5.5.1 When an assessment concludes that a concern or suspicion is unfounded, either initially or following any relevant appeals procedures, the files and records of the HSE Children and Family Services should reflect that fact.

5.5.2 Where a notification of suspected abuse has been made to An Garda Síochána, the HSE should also notify An Garda Síochána of this conclusion.

5.5.3 HSE staff may need to extend support to the family concerned and appropriate counselling services should be provided if required.

\subsection{Provision of child welfare services}

5.6.1 In many situations, preliminary enquiries/initial assessment may indicate there are child welfare concerns and that the parent(s) or carers may need support to adequately care for the child/children.

5.6.2 Intervention by way of family support services where child welfare concerns have been identified may help to prevent any deterioration of current difficulties being experienced by a family and assist the development of protective factors.

5.6.3 Family support services, by way of a family support plan, may be delivered formally through the direct services of statutory and voluntary organisations, and informally through the support of extended families, friends, neighbourhoods, communities, parishes and other local networks. Where support is being provided to a family where there are child welfare concerns, it needs to be coordinated and monitored by the HSE.

5.6.4 Local Health Office areas should have a plan, outlining the services available to provide support in child welfare cases. This family support service plan should take account of the views of all relevant service providers and representatives of community organisations.

5.6.5 Child welfare services by way of family support should aim to achieve the following:

(i) respond in a supportive manner to families where children's welfare is under threat;

(ii) reduce risk to children by enhancing their family life;

(iii) prevent avoidable entry of children into the care system;

(iv) address current problems being experienced by children and families;

(v) connect families with supportive networks in the community;

(vi) promote parental competence and confidence;

(vii) provide direct services to children;

(viii) where children have been in care, assist their re-integration with their families.

5.6.6 Parents/carers as well as children themselves may request a child welfare service directly or they may be referred by another source. A request for services should be responded to in a supportive and nonthreatening manner. Families should be encouraged to identify their own solutions as much as possible.

5.6.7 Following the identification of child welfare needs, the aim of assessment for family support services is to gain sufficient understanding of the needs and strengths of the child and his/her parents/carers in order to identify, offer and agree appropriate services. The assessment should incorporate individual and family needs. 
5.6.8 A child welfare plan should be based on an assessment and take the following factors into account:

(i) the level of agreement that either exists or is negotiable between parents/carers and others, such as family members, professionals and/or concerned other persons;

(ii) the concerns that require the most urgent attention;

(iii) short-term and long-term goals;

(iv) access to necessary resources;

(v) specified persons, disciplines or agencies that need to be involved;

(vi) the length of time that family support services may be required, bearing in mind that some families will need assistance only in times of crisis, others over a longer time;

(vii) a schedule for evaluation and review.

5.6.9 Where a review of the child welfare plan identifies an unresolved child protection issue or that the significant welfare needs of the child are not being met in a timely manner, the case must be referred for a child protection conference (see Section 5.8) in accordance with HSE procedures.

\subsection{Strategy Meeting}

5.7.1 The purpose of a strategy meeting is to facilitate the sharing and evaluation of information between professionals and to prepare a plan of action for the protection of a child, and the siblings if necessary. A strategy meeting may involve any or all of the professionals involved at either management or case assessment level, depending on the circumstances. It is important that the attendance of a Garda Síochána representative is secured at this meeting where appropriate, especially if a formal notification has been made.

5.7.2 It is the responsibility of the HSE Social Work Team Leader or Social Work Manager to hold a strategy meeting, if such a meeting is deemed necessary.

5.7.3 While, in the main, strategy meetings will be formally arranged, in certain circumstances, particularly where urgent, the strategy meeting may take the form of a less formal contact.

5.7.4 The objectives of the meeting are:

(i) to share available information;

(ii) to consider whether immediate action should be taken to protect the child and other children in the same situation;

(iii) to consider if Section 16(1)(b) of the Criminal Evidence Act 1992 interviews should take place;

(iv) to consider available legal options;

(v) to plan early intervention;

(vi) to identify possible sources of protection and support for the child;

(vii) to identify sources of further information;

(viii) to allocate responsibility;

(ix) to agree with An Garda Síochána how the remainder of the enquiry will be conducted;

(x) to identify if other children may be at risk and to take action. 


\subsection{Child Protection Conference}

5.8.1 A child protection conference is an interagency and interprofessional meeting, convened by the designated person within the HSE.

5.8.2 The purpose of a child protection conference is:

(i) to facilitate the sharing and evaluation of information between professionals and parents/carers;

(ii) to formulate a child protection plan (see Section 5.9);

(iii) to identify tasks to be carried out as part of, or pending, a child protection plan;

(iv) to specify the appropriate service to carry out the tasks;

(v) to appoint a key worker for the purpose of coordinating the child protection plan.

5.8.3 An invitation to attend a child protection conference and the agenda to be covered should be sent in the first instance to the Garda Superintendent in order to facilitate the attendance of the designated Garda, if appropriate.

5.8.4 By their nature, child protection conferences are both critical and complex. Specialist training should be provided to anyone undertaking the role of chairperson.

5.8.5 The meeting normally occurs following assessment and, if relevant, emergency actions have taken place. The child's parents/carers and the child should be included at the meeting unless doing so would not be in the child's best interests. In cases where there is a language barrier, or a disability or sensory impairment, those with particular expertise (e.g. interpreters) should be included.

5.8.6 The child protection conference and notification to the Child Protection Notification System (CPNS) (see Section 5.17) should be carried out in accordance with standard HSE protocols.

\subsection{Child Protection Plan}

5.9.1 A child protection plan is an interagency plan formulated at a child protection conference (see Section 5.8). It outlines the actions that professionals and agencies directly involved with the family need to take in order to ensure the child's continued protection and well-being. The basic components of a child protection plan are:

(i) identification of current and potential sources of risk to the child;

(ii) identification of strategies to protect the child and reduce the risks over a specified period;

(iii) identification of protective aspects of the child's situation, which may need to be strengthened and developed;

(iv) identification of short-term and long-term goals to be achieved to secure the protection and welfare of the child;

(v) consultation and negotiation with the child and his or her parents/carers on the content and feasibility of the plan;

(vi) identification of a key worker, who will continue to coordinate the work of various personnel involved in carrying out the plan and who will be responsible for ensuring communication of information between all the parties involved;

(vii) clear allocation of specific roles and responsibilities to all professionals and agencies directly involved in implementing the plan;

(viii) clear allocation of the roles and responsibilities to the child's parents/carers and other relevant family members; 
(ix) identification of resources necessary to carry out the plan, including family support and treatment services where required;

(x) consideration of the position of the abuser and need for treatment;

(xi) notification of the child's name to the Child Protection Notification System (CPNS) in accordance with standard HSE protocols (see Section 5.17);

(xii) identification of and agreement to a review date.

5.9.2 When a child protection plan has been put in place, it is the responsibility of all identified professionals and agencies to implement those parts of the plan that relate to them and to communicate with the key worker. In order to ensure that the plan is implemented, the following conditions must be observed:

(i) each professional must be given a written copy of the child protection plan;

(ii) a written copy of the plan should be given to the child, depending on his or her age and stage of development, and to his or her parents/carers;

(iii) the key worker must ensure that the child and family understand the nature and objectives of the plan;

(iv) the specific expectations of all parties about the plan and its implementation must be clarified;

(v) in addition to consultation about the plan, the child and his or her parents/carers should be given the names of all personnel involved in implementing the plan, together with their specific roles;

(vi) any changes of personnel should be immediately notified to the child and his or her parents/carers.

5.9.3 The successful implementation of a child protection plan will depend on a number of functions: interagency and interprofessional cooperation; ongoing consultation with the child and with his or her parents/carers; ongoing monitoring of the implementation of short- and long-term goals; and supervision and support.

5.9.4 Interagency and interprofessional cooperation: Cooperation between disciplines and agencies is as crucial to the longer term management of a case as it is at the outset. Commitment and flexibility in relation to carrying out the work specified in the child protection plan, together with willingness to exchange information promptly, will be required from all professionals involved with the child (see also Chapter 4, Section 4.3).

5.9.5 Ongoing consultation with the child: The views of the child must be privately sought on an ongoing basis and taken into consideration if modifying the child protection plan.

5.9.6 Ongoing consultation with the parents/carers: The views of the parents/carers must also be sought on an ongoing basis and taken into consideration if modifying the child protection plan.

5.9.7 Ongoing assessment: The protection and welfare of the child should be assessed on a continual basis to take account of changes in circumstances.

5.9.8 Supervision and support: All front-line practitioners working with the child and family should have consistent and regular support and supervision.

\subsection{Appointment of a key worker}

5.10.1 Where there are welfare concerns and a decision is made to offer services to a child and his or her parents/carers, a key worker must be identified. 


\subsection{Child Protection Review Conference}

5.11.1 Child protection review conferences are held initially 6 months after the child protection conference (see Section 5.8) or sooner if appropriate.

5.11.2 It is the responsibility of the designated person within the HSE to arrange child protection reviews conferences. Reviews should be attended by the core group of professionals involved with the case and each should submit a written report in advance. The child's parents/carers should attend, unless a specific reason for their exclusion is identified. The child may be involved depending on his or her age and level of understanding.

5.11.3 The child protection review conference has a number of purposes, including:

(i) to complete a full review of progress with evidence of positive or negative change in relation to the goals that were identified;

(ii) to coordinate the views and actions of professionals;

(iii) to consider the views of the child;

(iv) to consider the views of the parents/carers;

(v) to review the progress of any legal action or prosecution if relevant;

(vi) to review and amend the child protection plan and in particular to determine whether such a plan continues to be necessary;

(vii) to assess the availability of resources needed to carry out the child protection plan;

(viii) to recommend, where appropriate, the delisting of the child's name from the Child Protection Notification System in accordance with standard HSE protocols.

5.11.4 The child protection review should be documented as soon as possible and copies of the proceedings circulated to all professionals involved, as well as to the child and parents/carers. If the child and parents/carers have not attended the review, the key worker should give an explanation to them separately, or if appropriately together, of its contents, conclusions and implications.

\subsection{Emergency action to protect a child}

5.12.1 If a report made to the HSE Children and Family Services indicates the presence of immediate and serious risk, urgent action must be taken to protect any children in that situation who may be in danger.

5.12.2 This may be achieved by securing the cooperation of a protective carer, family member or other responsible adult in the child's home whose capacity to protect the child can be defined and agreed.

5.12.3 If it is not possible to make arrangements to have the child or children protected at home, they may need to be placed in the care of the HSE, preferably with the consent of the parents/carers, but if necessary using legal measures under the Child Care Act 1991. If emergency action has not already been agreed, consultation must take place between the practitioners involved and their line managers. Interventions involving the separation of children from their parents/carers can only be carried out by properly authorised officers with delegated powers from the Chief Executive Officer of the HSE. Legal advice must be sought at an early stage if Court action is planned.

5.12.4 It must be borne in mind that the removal of children from their parents/carers or their homes can be very stressful and requires sensitive handling. The likely effects of separation must be balanced against the danger of leaving the child at home. 
5.12.5 If it is considered necessary to remove a child from his or her parents/carers or home, then the following must be considered:

(i) In the first instance, all possible efforts should be made to place the child in a situation that is familiar, preferably with family or friends (see Child Care (Placement of Children with Relatives) Regulations 1995, published by the Department of Health).

(ii) As far as possible, the timing of the move should be sensitively handled.

(iii) The child's parents/carers should be informed of the action proposed, unless doing so would endanger the child or jeopardise the placement process.

(iv) The child should be informed of the proposed action if he or she has not been involved in the decision.

(v) The child's parents/carers should be informed of the child's location, unless otherwise directed by the Court.

(vi) The child's parents/carers should be advised about and assisted in obtaining legal advice.

5.12.6 In the majority of cases, the perceived harm or risk does not warrant such emergency action and the concern should be followed up in a planned coordinated manner. This involves communicating with all professionals involved with the child and enlisting their assistance if appropriate.

5.12.7 Under no circumstances should a child be left in a situation that exposes him or her to harm or risk of harm pending HSE intervention. In cases of emergency, where a child appears to be at immediate and serious risk and a HSE duty social worker is not immediately available, An Garda Síochána should be contacted.

\subsection{Closure of cases}

5.13.1 Cases must only be closed when there are no longer concerns regarding a child's protection or welfare. When a case is closed, all professionals involved and the child and family must be informed. Ideally, closure would ensue following a review, but if not, the designated person within the HSE must endorse the decision.

5.13.2 Where a child has been listed on the Child Protection Notification System, the name will be delisted in accordance with standard HSE protocols.

\subsection{Responsibility of the HSE Children and Family Services}

5.14.1 The HSE Children and Family Services are obliged to treat seriously all child protection and welfare concerns, whatever their source, and to consider carefully and fairly the nature of the information reported. In determining the most appropriate response, a balance needs to be struck between protecting the child and avoiding unnecessary and distressing intervention. The HSE response must:

(i) consider the protection and welfare of the child as the priority;

(ii) avoid actions that cause the child or family undue distress;

(iii) respect the rights of parents/carers to have their views heard and to be fully informed of any steps taken;

(iv) respect the rights of children to have their views heard. 


\section{Joint working with other professionals}

5.14.2 It is normally the role of social workers in the HSE Children and Family Services to carry out enquiries into reported concerns. However, other disciplines, such as public health nurses or clinical psychologists, may be allocated this task in certain cases where, for example, they have a close relationship with the family concerned. If a child protection concern has been notified to An Garda Síochána, it may conduct a parallel investigation in coordination with the HSE Children and Family Services (see Chapter 7).

5.14.3 Any professional making enquiries into a reported concern about child protection must first consider the issue of cooperation of the parents/carers. This is especially true if the professional is making enquiries of agencies external to the HSE. Professionals who work in the HSE may consult with their colleagues and check internal records at a preliminary stage. However, the parents/carers must be informed if the professional wishes to make enquiries of external agencies, except in exceptional circumstances. If a parent or carer refuses, the protection and welfare of the child must be the overriding consideration.

5.14.4 Professionals in voluntary agencies, schools, clinics or other settings are in a good position to observe a child and his or her relationship with parents/carers. It may be appropriate for a professional from one of these organisations to pursue the enquiry jointly with, or on behalf of, the HSE Children and Family Services. This should be discussed with the HSE Children and Family Services.

5.14.5 When suspicions of child abuse exist but cannot be ascertained, HSE social workers may encourage other professionals who are in contact with the child to substantiate or eliminate concerns in a sensitive manner. For example, a teacher may observe a child's behaviour, interactions with peers, school work or informal conversations. A therapist, child care worker or anyone working with a child might gently explore the reasons for particular actions or statements, or use a play situation to enable the child to express him or herself. Any strategies used in this manner should be agreed with the HSE social worker.

5.14.6 Professionals who contact or who are contacted by the HSE for information about a child in the course of an assessment should be informed in due course of the outcome where this is relevant to their professional care/treatment of the child.

5.14.7 Under Data Protection legislation, the HSE may not provide specific information on the outcome or status of a child protection assessment to the person who reported the concern except in the professional context outlined above. The HSE should contact such a person to let them know that their information has been of assistance, but not divulge further information.

5.14.8 It is the responsibility of the HSE social worker, or other key worker assigned, to collate all the information available and to make an initial assessment of risk to the child and any other children in the same situation. Such an assessment should be carried out within a standardised framework developed by the HSE.

\subsection{Confidentiality and anonymity}

5.15.1 All information regarding a concern or an assessment of child abuse should be shared on a 'need to know' basis in the interests of the child.

5.15.2 No undertakings regarding secrecy can be given. Those working with a child and family should make this clear to all parties involved.

5.15.3 Concerns about a child that are reported anonymously should be followed up fully in accordance with HSE standard procedures. If the report has been made through a third party, the person mediating should be requested to facilitate contact between the original person who reported the concern and the HSE Children and Family Services. If, however, contact is not facilitated, for whatever reason, the concerns reported via the third party must be fully investigated. 
5.15.4 It is preferable for the management of cases if those reporting concerns are encouraged to provide contact details.

5.15.5 Further details on confidentiality are given in Chapter 3, Section 3.9.

\subsection{Response to persons reporting concerns}

5.16.1 People who report or discuss their concerns about the care and protection of children with HSE staff should be informed of the likely general steps to be taken by the professionals involved.

5.16.2 Other professionals involved should be kept updated and informed about the outcomes of any enquiry or investigation into the reported concern, where this is appropriate to their professional care/treatment of the child or the performance of their own duties and within the normal limits of confidentiality.

\subsection{Child Protection Notification System}

5.17.1 The Child Protection Notification System (CPNS) is a HSE record of every child about whom the HSE is satisfied that there are unresolved child protection issues, including neglect.

5.17.2 A child's name is placed on the CPNS by the designated person within the HSE in accordance with the HSE child protection procedures.

5.17.3 The parent, guardian or carer, other relevant agencies and, where appropriate, the child should be informed when his or her name is listed on the CPNS.

5.17.4 The CPNS is the specific responsibility of the designated person within the HSE. It should be held securely and separately from other records. Information about how to access the CPNS should be available to all agencies concerned and held in a secure manner.

5.17.5 The system should record all enquiries, whether the child is on the list or not. If a CPNS enquiry is repeated, a report should be made to the HSE Children and Family Services.

5.17.6 Any changes in information relating to a child whose name is recorded on the CPNS should be referred to the child's allocated social worker, who, in turn, will inform the designated officer with responsibility for the CPNS, i.e. the designated person within the HSE.

5.17.7 It is the responsibility of the designated person within the HSE to ensure that the CPNS is managed and maintained in such a way as:

(i) to provide adequate information to appropriate professionals who have a need to access relevant information about a child;

(ii) to facilitate the provision of statistical information to appropriate sources.

5.17.8 The HSE should agree which professional groups require access and formulate procedures for confirming the identities of persons making enquiries. The HSE may amend this list in the light of changing circumstances and experience.

5.17.9 The name of the allocated social worker only should be given to the enquirer. The relevant social worker should be informed when an enquiry is made.

5.17.10 The CPNS should allow for 24-hour access. The HSE should keep relevant agencies and services up to date on how to access the system.

5.17.11 The CPNS should record case transfers when a child and/or his or her parents/carers move between jurisdictions or within the HSE to another area. 
5.17.12 Cases must only be closed and the child's name removed or delisted from the CPNS when the child (or children) is no longer considered at risk. When a case is closed and the name delisted, all professionals involved and the child and family must be informed. Ideally, closure would ensue following a child protection review, but if not, the designated person within the HSE must endorse the decision.

\subsection{Medical/Specialist examinations}

5.18.1 If there is reason to believe that a medical examination will indicate more clearly whether or not a child has been physically abused, or seriously deprived or neglected, or if a child appears to require medical treatment, then appropriate arrangements should be made immediately in consultation with An Garda Síochána. Wherever possible, a doctor with appropriate experience should carry out the examination.

5.18.2 If there is reason to believe that a specialist assessment will indicate more clearly whether a child has been sexually abused, a referral should be made to the appropriate service. If any doubt exists as to whether referral to a specialist unit is required, the child sexual abuse assessment service for the area should be consulted for an opinion. Only a doctor with appropriate training and experience should carry out a physical examination for sexual abuse.

5.18.3 In all cases where medical examinations or assessments for child sexual abuse are carried out, permission must be gained from the child's parents/carers, who should also be given the opportunity to attend. If permission is refused by the parents/carers, they should be advised of the HSE's option to apply for an Emergency Care Order or, if and where appropriate, a Supervision Order as provided for in the Child Care Act 1991. Such action should be considered if cooperation is still withheld.

5.18.4 The medical or specialist practitioner who carries out the examination or assessment must give a written report of the findings and must be made aware that he or she may be required to give evidence in Court.

\subsection{Case transfer}

5.19.1 The HSE Children and Family Services should have in place a Case Transfer Protocol. This should provide direction on the steps to be taken when a child about whom there are child protection or welfare concerns and/or his or her parents/carers move to another jurisdiction or to another area within the HSE. The protocol should state that, prior to the transfer of information to another jurisdiction, there is either consent, a legal basis or a child protection or welfare concern. It should also include the arrangements made for the transfer of relevant records relating to the child protection or welfare case.

\subsection{Serious Incident Reviews}

5.20.1 The HSE may instigate a Serious Incident Review in discharging its statutory role with regard to the protection and welfare of children having regard to the Health Information and Quality Authority's Guidance for the Health Service Executive for the Review of Serious Incidents, including deaths of children in care (HIQA, 2010).

5.20.2 A serious incident review is a review of the response, manner and quality of services provided to children and families. The purpose of the review is to learn lessons from the handling of specific cases so that deficits in the system can be addressed.

5.20.3 The National Review Panel is a functionally independent group, contracted by the HSE, that carries responsibility for reviewing serious incidents, including the deaths of children in care and those known to the child protection services. The Panel consists of an independent chair and deputy chair, and a number of independent professionals with expertise in relevant areas. It operates under the HIQA's (2010) Guidance for the Health Service Executive for the Review of Serious Incidents, including deaths of children in care. Deaths or serious incidents are notified by the HSE to the HIQA and to the National Review Panel; if they fall within the criteria laid down in the Guidance, they will be reviewed by the National Review Panel. 
All deaths and serious incidents conforming to the following criteria are notifiable:

- all deaths of children in care;

- all deaths of children known to the HSE child protection system;

- all deaths of young adults (up to 21 years) who were in the care of the HSE in the period immediately prior to their 18th birthday or were in receipt of aftercare services;

- when a case of suspected or confirmed abuse involves the death of a child known to the HSE or a HSE-funded service;

- a death or potentially life-threatening injury, or serious and permanent impairment of health, well-being or development.

5.20.4 There may be cases where the National Review Panel, in consultation with the HSE, considers that it would be more appropriate for a death or serious incident review to be conducted at local level. In such cases, the review should be conducted by a HSE senior staff member who is not involved with the case, using the methodology prescribed in the HIQA's Guidance.

When a review is conducted locally, the report must be forwarded to the National Review Panel. If questions arise concerning either the quality or independence of the review, the National Review Panel will then conduct the most appropriate type of review. The review will ultimately be forwarded to the HIQA.

5.20.5 The HIQA's Guidance states that the purpose of these reviews is as follows:

'Reviews are completed for the following reasons:

- to determine the specific circumstances leading to the death or serious incident, and ascertain whether abuse, or whether an act or failure to act, was a contributing factor to the child's death or serious incident. The review may also identify whether other separate actions, such as disciplinary action or a referral to any regulatory body, need to be undertaken;

- to determine whether compliance with Children First and other set down procedures and the relevant standards of governance (leadership, organisation and management, business planning, risk management and meeting the legal requirements) and accountability among the professionals and service providers were satisfactory within the context of the information available at the time;

- to make recommendations and develop an action plan;

- to provide reassurance to the public on the standards of care and protection provided to children, that reviews are carried out to an appropriate standard and are independently monitored and published as appropriate;

- a review or a number of reviews viewed together may identify system-wide strengths and weaknesses, and the findings used to provide high-quality and safe care to people using health and social care services.'

5.20.6 In addition to the above, the HIQA may undertake a separate investigation as set out in Section 9 of the Health Act 2007.

\subsection{Record-keeping}

5.21.1 Record-keeping is of critical importance in this area of work. Unless accurate records are maintained, the ability to adequately protect vulnerable children may be severely curtailed. It is essential that professionals keep contemporaneous records of all reported concerns in a safe place. These should include details of contacts, consultations and any actions taken. 
5.21.2 Case notes must be kept for the following reasons:

(i) to record details of referral, investigation and assessments of child care concerns;

(ii) to record essential details concerning the child and his or her parents/carers;

(iii) to record the nature and level of services offered, as well as those that are required;

(iv) to establish a record that may be accessed by a number of professionals and agencies where this arises in the assessment of the child care concern;

(v) to record and review developments in a case;

(vi) to provide a tool for use in the supervision of professional work;

(vii) to establish a measure of accountability between practitioners and their line managers;

(viii) to facilitate case transfers or the transfer of information between key professionals from different areas in line with the Children First: National Guidance.

5.21.3 Comprehensive, standardised case notes, consistent with Children First principles (see Chapter 1), must be kept in accordance with best practice and in a manner to be prescribed by the HSE. The management of child protection records within the HSE is to be strengthened through the development of a National Child Care Information System.

5.21.4 The management of records held by the HSE social worker or other designated key worker should be standardised throughout the HSE. Each child should have an individual file containing the following:

(i) a summary sheet containing family details;

(ii) a record of all enquiries made about the case and the response obtained;

(iii) a record of all contacts between the worker and the child and his or her parents/carers;

(iv) a record of all contacts between the worker and other professionals, including working arrangements and agreements;

(v) a summary, to be updated regularly, on recent events and their significance;

(vi) a report of all Court proceedings, child protection conferences, reviews and any other meetings, as well as any other relevant documentation in the worker's possession;

(vii) details of assessment and outcomes;

(viii) a record of any decisions made;

(ix) a copy of any child protection plans;

(x) a copy of all correspondence about the case.

5.21.5 Records should be factual, accurate and legible; should be dated and signed after each entry; and should be recorded on the day that the action took place or, at the latest, the following day. If an assessment or evaluation is made, an explanation for its basis must be offered.

5.21.6 Records should be signed off by the line manager.

5.21.7 Records should be accessible at all times during a key worker's absence from the office, but must be stored in a secure manner that ensures they are only available on a strictly 'need to know' basis. It is the responsibility of line managers to ensure that files are kept up to date and good recording practices are maintained. 


\section{Supervision, Support and Additional Guidance for HSE child protection and welfare work}

\subsection{Corporate risk strategy and staff supervision and support policy in the HSE}

6.1.1 Given the nature of child protection and welfare work, the HSE as an employer should have the risks involved in child protection and welfare work included in its Corporate Risk Strategy and should implement risk assessment procedures accordingly.

6.1.2 The HSE should ensure that there is a Staff Supervision and Support Policy in place that supports the staff involved in the delivery of child protection and welfare services.

6.1.3 It is essential that managers of all disciplines involved in child protection and welfare work acknowledge the levels of actual or potential stress that may affect their staff, including when clients may exhibit aggressive behaviours, and take steps to address any problems. These steps may include:

(i) adequate and regular supervision of staff;

(ii) regular review of caseloads;

(iii) acknowledgement of positive achievement;

(iv) provision of opportunities for professional development, such as training, staff rotation, special assignments;

(v) development of interagency links;

(vi) putting in place the necessary arrangements and procedures to ensure the safety and security of child protection and welfare staff.

\subsection{Guidance on allegations against employees and volunteers}

6.2.1 The HSE Children and Family Services receive allegations of abuse against people who have contact with children in their workplace or in a recreational setting. If the HSE considers that children are, or may be, at immediate risk from the alleged abuser, contact should be made with the institution or employer immediately. In this situation, it is not necessary to notify the alleged abuser in advance of the allegations against him or her.

6.2.2 Where the HSE proposes to notify an alleged abuser's employer or person-in-charge where he or she attends, and where there is no immediate danger to children, the alleged abuser must be notified in advance of the allegations against him or her. The approach to an employer or person-in-charge in such cases may take place at any stage in a wider investigation and it may be practical that such an approach does not occur until any criminal investigation or HSE assessment has concluded.

6.2.3 The HSE Children and Family Services should provide feedback to the employer or person-in-charge on the progress of a child abuse assessment/investigation involving an employee. The HSE should seek to complete its assessment as quickly as possible, bearing in mind the serious implications for innocent employees. Employers or persons-in-charge should be notified of the outcome of the HSE assessment and/or the Garda investigation. This will assist them in reaching a decision about the action to be taken in the longer term concerning the employee. 


\subsection{Guidance on interviewing parents/carers}

6.3.1 When a concern about a child's care or protection is reported to the HSE Children and Family Services, the child's parents/carers should be contacted by a HSE social worker or other professional who has agreed to carry out this assessment task. It must be borne in mind that the experience of being contacted by the HSE Children and Family Services about the care and protection of one's children can be both traumatic and intimidating for parents/carers; thus a degree of sensitivity must be used in conducting the interviews. The quality of any relationship that may later exist between the family and professionals will be influenced by the manner in which this initial meeting is handled.

6.3.2 If An Garda Síochána has already been notified and is likely to be carrying out a parallel investigation, it is essential that the activities of the two organisations are agreed and coordinated (see Chapter 7).

6.3.3 All professionals, whether in the HSE Children and Family Services or other services, should observe the following procedures when interviewing parents/carers:

(i) inform parents/carers in an open and honest way of existing concerns and reports about their child or children;

(ii) explain how information about the case has been, and will be, obtained;

(iii) identify the professionals who have been contacted so far;

(iv) invite the parents/carers to give an explanation of their view of the concern;

(v) show a willingness to consider different interpretations of the concern;

(vi) ensure that the parents/carers are fully aware of the way that information is going to be assessed and evaluated, and what expectations are held of them about the way they care for and protect their children;

(vii) if relevant, explain the legal context in which the concern is being investigated;

(viii) if the concern arose from an incident perpetrated by one of the child's parents/carers, the worker should try to gain the support and cooperation of the other parent/carer to facilitate ongoing protection of the child.

6.3.4 Where the interests of the parents/carers and the child appear to conflict, the child's interests must be considered paramount. It may be necessary to provide a separate worker for each of the parents/carers if, for example, one of them is the alleged abuser.

\subsection{Guidance on interviewing children}

6.4.1 In the course of child protection work, different types of interview may be carried out with children. In most instances, depending on the nature of the concern, the child should be seen by the professional conducting the enquiry or assessment and spoken to personally, in a manner appropriate to his or her age and stage of development. The child should not usually be interviewed in the first instance in detail about sexual or serious physical abuse. This may be done more appropriately at a later stage by specially trained social workers or An Garda Síochána, or both.

6.4.2 The interview should take place in a location that is comfortable for the child and, if the child desires it, in the presence of a support person, such as a protective parent/carer, another professional or an adult friend. If the child has a learning disability or sensory impairment, it may be necessary to employ expert assistance to facilitate communication. It is important that the child is not interviewed in the company of any person who may have a vested interest in the child's version of events or who might influence what the child may say. 
6.4.3 Section 16(1)(b) of the Criminal Evidence Act 1992 states that the video recording of statements by children under 14 years during an interview with a member of An Garda Síochána or other competent person shall be admissible as evidence in Court. Special facilities for the holding of such interviews have been developed, together with training for social workers and Gardaí undertaking such interviews.

6.4.4 Interviews with children should normally be carried out with the permission of their parents/carers and the child must be able to give his or her own consent.

6.4.5 In some circumstances, children may present themselves to a HSE social worker without either the knowledge or presence of their parents/carers. Depending on the perceived maturity of the child, the social worker should give them the opportunity to discuss whatever concerns have prompted them to make contact.

6.4.6 No avoidable action should be taken that will cause a child to feel intimidated or distressed. The worker must use language that the child can understand and explain who they are and why they are there. It is essential to conduct the interview at the child's pace and communicate with him or her in a warm and responsive manner.

6.4.7 The reasons for interviewing the child include:

(i) to get a picture of the child's physical and emotional state;

(ii) to establish whether the child needs urgent medical attention;

(iii) to hear the child's version of the circumstances leading to the concern;

(iv) to get a picture of the child's relationship with their parents/carers;

(v) to support the child to participate in decisions affecting them according to their age and maturity;

(vi) to find out who the child trusts;

(vii) to inform the child of any further steps to be taken in the enquiry.

6.4.8 It is the responsibility of the HSE to ensure that staff carrying out child protection and welfare enquiries have sufficient training and experience in interviewing children. If the child is not present and the parents/ carers are not willing to cooperate in allowing him or her to be seen, the matter should be brought to the attention of the key worker's line manager and a decision made regarding any further action.

\subsection{Conflict between parents/carers and children}

6.5.1 Where the interests of the parents/carers and child appear to conflict, the child's interests should be paramount. It may be necessary in such circumstances for professionals to provide a separate worker specifically for the parents/carers, in particular where one of the parents/carers is the alleged abuser. 


\section{Protocol for An Garda Síochána - HSE Liaison}

\subsection{Introduction}

7.1.1 The HSE and An Garda Síochána are the key agencies empowered by law to carry out assessments and investigations, respectively, of suspected child abuse and neglect. Each agency manages the responsibility within its brief and their joint efforts are designed to ensure that the protection of vulnerable children receives priority attention. Their separate and complementary roles require careful understanding if the shared objectives of child protection are to be realised. An Garda Síochána has the additional responsibility of preparing an investigation file for the directions of the Director of Public Prosecutions (DPP), who decides on and carries out prosecutions.

7.1.2 An Garda Síochána is vested with the power to remove a child to safety under Section 12 of the Child Care Act 1991 where a member of the Gardaí has reasonable grounds for believing that there is an immediate and serious risk to the health or welfare of a child and it would not be sufficient for the protection of that child to await the making of an application for an Emergency Care Order by the HSE under Section 13 of the Child Care Act 1991. Where a child has been removed by An Garda Síochána under Section 12, the child shall be delivered into the custody of the HSE as soon as possible.

7.1.3 Note that where 'the HSE' is referred to in this chapter, it refers to the staff working in the HSE Children and Family Services.

\subsection{Designated personnel}

7.2.1 It is essential that the HSE and An Garda Síochána designate personnel at assessment/investigation and management levels who will remain involved with the case until the assessment/investigation is completed.

7.2.2 A Social Work Team Leader from the HSE and a designated Inspector/Sergeant from within An Garda Síochána should constitute a Liaison Management Team, the functions of which are:

(i) to consider the notification to An Garda Síochána of suspected child abuse or neglect;

(ii) to assign additional personnel, where necessary, and supervise investigations;

(iii) to review progress in the case.

\subsection{Tracking systems}

7.3.1 It is important for both the HSE and An Garda Síochána to chart the progress of an assessment/investigation into a notified suspicion of child abuse or neglect. A standardised Record of Garda - HSE Liaison Form should be used to assist managers and other personnel in this task (see Appendix 6). The adoption of this procedure should ensure accountability in all cases.

\subsection{Cases to be formally notified by the HSE to An Garda Siochána}

7.4.1 Where the HSE suspects that a child has been or is being physically or sexually abused or wilfully neglected, An Garda Síochána must be formally notified in accordance with the procedure set out in Paragraph 7.4.5 below. The process of establishing whether grounds exist for suspecting such abuse may involve consulting relevant professional personnel within the HSE and, where appropriate, in outside agencies. However, the HSE must not await confirmation of such abuse, whether from a child abuse assessment unit or otherwise, before notifying An Garda Síochána. 
7.4.2 In all such cases, the HSE must inform the person reporting a suspicion of child abuse that their information will be shared with An Garda Síochána.

7.4.3 The HSE is not expected to routinely notify suspected cases of emotional abuse or unintentional neglect to An Garda Síochána since the circumstances of such cases may not involve law enforcement issues. In cases of doubt, however, An Garda Síochána should be consulted as to whether a notification may be necessary.

7.4.4 On occasion, the HSE may become aware of abuse to unknown children involving being photographed, videotaped or filmed for pornographic purposes without their knowledge. This information should be conveyed to An Garda Síochána.

\section{Procedure for the HSE to notify An Garda Síochána}

7.4.5 The procedure for the HSE to notify An Garda Síochána of a suspected case of physical or sexual abuse, or wilful neglect of a child is as follows:

(i) The designated person within the HSE sends the Standard Notification Form to the local Garda Superintendent (see Appendix 4). Where more than one child is involved, a separate Standard Notification Form should be sent in respect of each child. A copy is retained in the file on each child. The social worker handling the case (or other designated person) is named on the form.

(ii) On receipt of the Standard Notification Form, the Garda Superintendent arranges to have a designated Garda assigned to the case and immediately informs the designated person within the HSE of the Garda's name and station.

(iii) The designated Garda makes direct contact without delay with the HSE social worker (or other designated person) dealing with the case in order to obtain details.

(iv) When contact is established, both the designated Garda and the social worker commence completion of the Record of Garda - HSE Liaison Form (see Appendix 6).

(v) At the same time, the Garda Superintendent will assign a designated Inspector/Sergeant to manage the investigation, monitor its progress and consult with the appointed HSE designated person of the case.

(vi) Where contact cannot be established between the designated Garda and the social worker, the matter will revert immediately to the HSE Social Work Team Leader of the case and the designated Garda Inspector/Sergeant for resolution.

\subsection{Informal consultation}

7.5.1 In cases where the HSE is aware of concerns about a child but is unable to establish sufficient grounds for formal notification, the HSE should consult with An Garda Síochána on an informal basis. Such contact is to be actively encouraged in order to protect the welfare of the child concerned.

\subsection{Emergency intervention}

7.6.1 In circumstances where a child's immediate safety is deemed to be at risk, the HSE is obliged to take immediate protective action. It is essential that the HSE informs An Garda Síochána as soon as possible of any actions taken or planned, by sending the Standard Notification Form as soon as circumstances permit (see Appendix 4). 


\subsection{Cases to be formally notified by An Garda Siochána to the HSE}

7.7.1 Where An Garda Síochána suspects that a child has been or is being the victim of emotional, physical or sexual abuse or neglect (whether wilful or unintentional), the HSE must be formally notified in accordance with the procedure set out in Paragraph 7.7.4 below. It is not necessary for An Garda Síochána to have sufficient evidence to support a criminal prosecution before notifying the HSE.

7.7.2 An Garda Síochána should notify the HSE of cases if they give rise to child protection issues, such as when the suspected abuser has ongoing contact with other children. In cases involving law enforcement only, An Garda Síochána should contact the HSE where there is need for appropriate counselling and other support services for the victims of assaults.

7.7.3 An Garda Síochána may be involved in investigating a case of child abuse, or a retrospective disclosure of abuse, where the HSE is not involved. Where appropriate, An Garda Síochána should seek the advice of the HSE regarding counselling and other support services for victims.

\section{Procedure for An Garda Síochána to notify the HSE}

7.7.4 The procedure for An Garda Síochána to notify the HSE of a suspected case of emotional, physical or sexual abuse or neglect of a child is as follows:

(i) The Garda Superintendent sends the Standard Notification Form to the designated person within the HSE (see Appendix 5). A copy is held by the designated Garda dealing with the case and by the designated Garda Inspector/Sergeant. Where more than one child is involved, a separate Standard Notification Form should be sent in respect of each child.

(ii) On receipt of the notification form, the designated person within the HSE arranges, through the HSE Social Work Team Leader, to have a social worker (or other designated person) assigned to the case and immediately notifies the Garda Superintendent of the name and location of the designated social worker.

(iii) The social worker assigned to the case makes direct contact without delay with the designated Garda in charge of the case in order to obtain details.

(iv) When contact is established, both the designated Garda and the social worker commence completion of the Record of Garda - HSE Liaison Form (see Appendix 6).

(v) At the same time, the Garda Superintendent will assign a designated Inspector/Sergeant to manage the investigation, monitor its progress and consult with the appointed HSE manager of the case.

(vi) Where contact cannot be established between the designated Garda and HSE social worker, the matter will revert immediately to the HSE Social Work Team Leader and the designated Garda Inspector/Sergeant for resolution.

7.7.5 The Liaison Management Team - comprising the HSE Social Work Team Leader and the Garda Inspector/Sergeant - will be responsible for ensuring that interagency liaison occurs and that each Standard Notification Form is appropriately processed, as follows:

- Within An Garda Síochána, the notification process requires that the Standard Notification Form from the HSE (see Appendix 4) must be received by the designated Garda, the designated Garda Inspector/ Sergeant and the Garda Superintendent.

- Within the HSE, the notification process requires that the Standard Notification Form from An Garda Síochána (see Appendix 5) must be received by the designated social worker, the designated Social Work Team Leader and designated person within the HSE. 


\subsection{Informal consultation}

7.8.1 In cases where An Garda Síochána is aware of concerns about a child but is unable to establish sufficient grounds for formal notification to the HSE, An Garda Síochána should consult with the HSE on an informal basis. Such contact is to be actively encouraged in order to protect the welfare of the child concerned.

\subsection{Emergency intervention}

7.9.1 There may be occasions when An Garda Síochána has to take immediate action to protect a child without first notifying the HSE. It is essential that An Garda Síochána informs the HSE as soon as possible of any actions taken, by sending the Standard Notification Form as soon as circumstances permit (see Appendix 5).

\subsection{Assessment and Investigation of cases}

7.10.1 It is essential that enquiries by the HSE and An Garda Síochána should be coordinated to ensure that:

(i) the welfare of the child is protected;

(ii) everything possible is done to assist the criminal investigation and protect the available evidence;

(iii) there is an effective flow of relevant information between both agencies;

(iv) decisions and actions follow consultation within and between both agencies.

\subsection{Matters to be considered by the HSE and An Garda Siochana during the assessment, investigation and management of suspected child abuse cases}

7.11.1 Interviewing: In cases where a specialist assessment of child sexual abuse is underway, the early interviewing of the child by An Garda Síochána should be facilitated to ensure that statements may be obtained in a manner least likely to cause stress to the child (see Chapter 6, Section 6.4). It is important to note that the person who initially reported the allegation of child sexual abuse, or to whom the allegation was made, may be a vital witness and should be interviewed by An Garda Síochána at an early stage. Section 16(1)(b) of the Criminal Evidence Act 1992 states that the video recording of statements by children under 14 years during an interview with a member of An Garda Síochána or other competent person shall be admissible as evidence in Court. Special facilities for the holding of such interviews have been developed, together with training for social workers and Gardaí undertaking such interviews.

7.11.2 Record-keeping: The HSE and An Garda Síochána should keep a written record of decisions taken in relation to the case (see Chapter 5, Section 5.21). This record should be accessible in the absence of the specific personnel allocated to the case. All contacts between the HSE and An Garda Síochána should be recorded. A decision that is made by either the HSE or An Garda Síochána not to proceed must be recorded in detail.

7.11.3 Child Protection Plan: All persons involved should agree a child protection plan. Plans will be reviewed on an ongoing basis (see Chapter 5, Section 5.9).

7.11.4 Strategy Meetings and Child Protection Conferences: An invitation to attend and the agenda to be covered should be sent in the first instance to the Garda Superintendent in order to facilitate the attendance of the designated Garda, if appropriate.

7.11.5 Liaison with parents/carers: Every possible effort should be made to keep the child's parents/carers informed of developments in the case, except where this might place the child at further risk or impede the criminal investigation. It is common practice to invite parents/carers to attend child protection conferences. If this conflicts with the investigative process, the matter should be resolved between the relevant case 
managers, namely the Social Work Team Leader and the designated Garda Inspector/Sergeant. The views of parents/carers should be sought on the issues to be raised at a child protection conference, so that they can get advice and prepare their representations. All actions in response to concerns about child abuse should be taken in a manner that supports the possibility of families providing safe and nurturing care for their children, now or in the future. For parents/carers, being asked to participate in, or cooperate with, an investigation into suspected child abuse can provoke powerful emotions, such as anger, fear, shame, guilt or powerlessness. Moreover, parents/carers are usually unaware of the complexity of what is likely to be involved and are unsure of the appropriate rules of behaviour.

Professionals need to try to build trust with families when involved in child abuse assessments/investigations in so far as is possible. It may be unrealistic to expect the HSE/Garda and families to trust each other in such difficult circumstances. Nevertheless, in many cases a relationship of trust can be established if the professionals involved create the right conditions for its development.

If the child or parent/carer has a communication difficulty, arrangements must be made to help them during any interviews. This may involve a sign language interpreter, large print, tape or braille. For those whose first language is not English, the services of an interpreter should be made available.

7.11.6 Extra familial abuse: Where a concern is made known to the HSE or An Garda Síochána that a child is at risk or has been abused by a person outside the family, the HSE shall:

(i) undertake an assessment of need on the child and provide support as required;

(ii) endeavour to undertake a risk assessment of the alleged perpetrator, where known, in accordance with HSE policy.

7.11.7 Investigation of organised abuse: The investigation of organised abuse requires particularly sensitive cooperation between the HSE and An Garda Síochána. It may involve surveillance work and a higher degree of secrecy than would normally be expected in child protection work. It may be undesirable to share information fully with families in the early stages of investigation since breaches of confidentiality may seriously impede detection (see Paragraphs 7.16.9-12).

\subsection{Confidentiality}

7.12.1 It is essential that all information exchanged between the HSE and An Garda Síochána is treated with the utmost confidentiality in order to safeguard the privacy of the children and families concerned and to avoid prejudicing any subsequent legal proceedings.

7.12.2 Regard must be taken of the Freedom of Information Acts 1997 and 2003 when considering a request for confidentiality (see Appendix 7). At present, these Acts apply to the HSE, but not to An Garda Síochána. HSE records containing references to communications with An Garda Síochána, including records of meetings where Gardaí are in attendance, will be considered 'third party' records and, as such, will be referred to the Garda Commissioner when any request for information release under the Freedom of Information Acts is being considered.

7.12.3 Similar considerations will apply to requests received under the provisions of the Data Protection Acts 1988 and 2003 (see Appendix 7).

\subsection{Ongoing liaison}

7.13.1 The HSE social worker and the designated Garda should stay in regular contact and inform each other of developments in the case as they take place and record these on the Record of Garda - HSE Liaison Form (see Appendix 6). The link between both agencies should be maintained until the criminal investigation and the prosecution (where applicable) is completed. 
7.13.2 Certain aspects of the investigation should be considered by both agencies, including:

(i) impact of a prosecution on the child (victim);

(ii) impact of the alleged abuse on the child;

(iii) support for child and adult witnesses;

(iv) victim support services.

\subsection{Strategy Meeting}

7.14.1 The purpose of a strategy meeting is to facilitate the sharing and evaluation of information between professionals and to prepare a plan of action for the protection of a child, and their siblings if necessary. A strategy meeting may involve any or all of the professionals involved at either management or case assessment level, depending on the circumstances. It is important that the attendance of a designated Garda is secured at this meeting where appropriate, especially if formal notification procedures are, or have been, invoked.

7.14.2 It is the responsibility of the HSE Social Work Team Leader or Social Work Manager to hold a strategy meeting.

7.14.3 While, in the main, strategy meetings will be formally convened, in certain circumstances, particularly where urgent, the strategy meeting may take the form of a less formal contact.

7.14.4 The objectives of the meeting are outlined in detail in Chapter 5, Paragraph 5.7.4.

\subsection{Child Protection Conference}

7.15.1 A child protection conference is an interagency and interprofessional meeting, convened by the designated person within the HSE (see Chapter 5, Section 5.8).

7.15.2 The purpose of a child protection conference is to facilitate the sharing and evaluation of information between professionals and parents/carers, and to formulate a child protection plan (see Chapter 5, Section 5.9).

7.15.3 An invitation to attend a child protection conference and the agenda to be covered should be sent in the first instance to the Garda Superintendent in order to facilitate the attendance of the designated Garda, if appropriate.

\subsection{Special considerations}

7.16.1 Certain child protection concerns that come to the attention of the HSE are of particular relevance to An Garda Síochána.

\section{Age of consent}

7.16.2 For the purposes of criminal law, the age of consent to sexual activity is 17 years. This means, for example, that a sexual relationship between two 16-year-olds who are boyfriend and girlfriend is illegal, although it might not be regarded as constituting 'child sexual abuse'. In any event, investigations should be sensitive to the needs of the child.

7.16.3 In cases where abuse is not suspected or alleged but the boy or girl is underage, consultation must be held between the HSE and An Garda Síochána, and all aspects of the case will be examined. Both agencies must acknowledge the sensitivity required in order to facilitate vulnerable young people in availing of all necessary services, while at the same time satisfying relevant legal requirements. 


\section{Underage pregnancy}

7.16.4 When a pregnant girl under 17 years presents to a health service, a health professional will attempt to establish whether there is any cause for concern regarding child sexual abuse. Where concerns exist, the health professional will refer the case to the HSE Children and Family Services.

7.16.5 Where such abuse is suspected or alleged and the designated person within the HSE has been so informed, then An Garda Síochána must be notified by the designated person within the HSE using the Standard Notification Form (see Appendix 4).

7.16.6 In cases where abuse is not suspected or alleged, HSE procedures should be in place to provide guidance on consultation with An Garda Síochána to examine all aspects of such cases. Both agencies must acknowledge the sensitivity required in order to facilitate vulnerable young girls to avail of medical or therapeutic services, while at the same time satisfying relevant legal requirements.

\section{Retrospective disclosure by adults}

7.16.7 When a disclosure is made by an adult of abuse suffered during their childhood and it comes to the attention of either the HSE or An Garda Síochána or other service, it is essential to establish whether there is any current risk to any child who may be in contact with the alleged abuser revealed in the adult's disclosure. If any risk is deemed to exist, this information must be shared between both agencies, following the notification procedures (see Paragraphs 7.4.5 and 7.7.4). It is essential that all relevant information in relation to any of the above eventualities is carefully collated and that each agency informs the other of any such concerns during an investigation.

7.16.8 The need to refer an adult for counselling, treatment and/or other support services for victims of assaults should also be considered.

\section{Organised abuse}

7.16.9 Cases of organised abuse comprise only a very small proportion of the child protection concerns that come to the attention of the HSE. Nevertheless, they are complex and require particularly careful handling. Essentially, organised abuse occurs either when one adult moves into an area or institution and systematically entraps children for abusive purposes (mainly sexually) or when two or more adults conspire to similarly abuse children, using inducements.

7.16.10 Organised abuse can occur in different settings, such as the community, clubs, the family or extended family, or an institution.

7.16.11 The following factors are particularly associated with organised abuse:

(i) Detection can take several years.

(ii) Calculating the number of victims involved can be difficult since many will have moved away from the area. Particular efforts, such as helplines and advertisements, may be required in order to contact victims.

(iii) Victims who grew up in care are often more powerless and vulnerable than those in other abuse cases.

(iv) Victims may be under particular pressure not to disclose because of threats or feelings of shame and responsibility.

(v) Some victims may have helped abusers to entrap other children and may have gone on to become abusers themselves.

(vi) Families may have unwittingly colluded with the abuse by accepting gifts and friendship from the abuser and encouraging their children to associate with the abuser. 
7.16.12 The investigation of organised abuse requires particularly sensitive cooperation between the HSE and An Garda Síochána. It may involve surveillance work and a higher degree of secrecy than would normally be expected in child protection work. It may be undesirable to share information fully with families in the early stages of investigation since breaches of confidentiality may seriously impede detection.

\subsection{Arrangements for the protection of children at risk in other areas or jurisdictions}

7.17.1 When a family with children who are considered by the HSE or An Garda Síochána to be at risk are believed to have moved from one area to another within the State, the relevant information will be furnished to the appropriate Local Health Office. The HSE will develop a protocol for the exchange of information in these circumstances, taking account of data protection considerations.

7.17.2 When a family with children who are considered by the HSE or An Garda Síochána to be at risk are believed to have moved to another jurisdiction, the relevant information should be sent to the appropriate authority in that State. The HSE will develop a protocol for the exchange of information in these circumstances, as well as in circumstances where a person whom the HSE considers poses a risk to children moves to another jurisdiction, taking account of data protection considerations.

7.17.3 Information on children who are in need of care and protection who move to countries other than the United Kingdom must be sent through the Irish correspondent for International Social Service (ISS), who will forward it to the appropriate ISS contact in the relevant country. To avail of the ISS network, the relevant information should be sent to the Irish ISS correspondent at:

International Social Service

HSE West

South East Wing

St. Joseph's Hospital

Mulgrave Street

Limerick, Co. Limerick, Ireland

Tel: 0035361461380

Fax: 0035361412355

E-mail: ISS@hse.ie

\subsection{Arrangements for the protection of children at risk who migrate to Ireland from another jurisdiction}

7.18.1 Information received from the International Social Service (ISS) on children who are in need of care and protection who come to Ireland from abroad is channelled through the Irish ISS correspondent at the address given in Paragraph 7.17.3 above.

7.18.2 When the HSE or An Garda Síochána is informed that children who are considered to be at risk have moved into their area, immediate notification procedures must be followed. If required, a strategy meeting must be arranged between the HSE and An Garda Síochána to review relevant information. 


\section{PART IV: Special Considerations}




\section{Especially vulnerable children}

\subsection{Purpose}

8.1.1 This chapter provides additional guidance on children who may be especially vulnerable and who may have been abused or neglected, or who are at risk of abuse or neglect. These include:

- children in residential settings;

- children in the care of the State under the Child Care Act 1991:

- foster care;

- relative care;

- residential care.

- children who are homeless;

- children with disabilities;

- separated children seeking asylum;

- children being trafficked.

\subsection{Role of the HSE}

8.2.1 Under the Child Care Act 1991, the HSE is required to assume primary responsibility for an assessment and to take appropriate steps to protect the welfare of the child or children in question. In practice, this means that the designated person within the HSE coordinates the services necessary to identify whether a particular child, or children, needs care or protection, and if so to initiate appropriate action. In doing this, the designated person will liaise closely with the referring service and, where required, enlist its assistance.

\subsection{Role of the HIQA and SSI}

8.3.1 The Health Information and Quality Authority (HIQA) has statutory responsibility for developing Standards for Health and Social Services, including Standards for Children's Services. The national standards developed for children's services include good practice guidance on keeping children and young people safe and protected.

8.3.2 The Social Services Inspectorate (SSI) of the HIQA has responsibility for inspecting HSE children's residential centres, special care, hostels, relative/foster care and Children Detention Schools, including how child protection is practised. (The HSE registers and inspects children's residential centres and hostels run in the private and voluntary sectors.) When fully commenced under the Health Act 2007, the SSI will register and inspect all residential accommodation for children in care and residential care for adults and children with disabilities.

\subsection{Children in residential, educational and recreational settings}

8.4.1 All those involved in caring for children in residential settings, including those for educational and recreational purposes, outside of the home must be alert to the possibility of abuse by other children, visitors and members of staff. Policies and procedures aimed at preventing abuse must be in place. There must be clear written procedures on how to deal with suspected abuse. These must be accessible to children and staff.

8.4.2 When a child has been abused by another child in a residential setting, child protection procedures should be applied to both the abuser and the victim. 


\subsection{Safeguarding children in residential settings}

8.5.1 Children in residential settings should have contact outside the residence. These children may be particularly vulnerable and may find it very difficult to make their problems known. The following measures should be in place in all residential settings for children:

(i) a complaints system should be in place and children should be told about it and how to use it if they need to;

(ii) children should have easy access to a telephone where they can speak privately;

(iii) children should be made aware of telephone helpline numbers;

(iv) approved visitors from outside the residence should be available to see the children.

\subsection{Abuse of children in residential settings by visitors}

8.6.1 The possibility of abuse by visitors must be recognised and protected against. If such abuse occurs, it should normally be dealt with in the same way as other incidents of suspected abuse.

\subsection{Abuse or neglect of children in residential settings by staff}

8.7.1 Children and staff must be able to report their concerns. There should be clear written guidance on reporting suspected abuse or neglect. The need to be vigilant and to report concerns should be reinforced through training and supervision.

8.7.2 Children and staff need to be reassured that raising concerns is important. Management should respond to all reports of a concern quickly and appropriately, and ensure that effective action is taken. A written record of the report should be confirmed with the person who reported the concern.

8.7.3 Throughout the investigation, all interviews with children should be pre-arranged and the children should be provided with the following:

(i) support;

(ii) information about the investigation and its outcome;

(iii) privacy during interviews and in access to the telephone and correspondence;

(iv) access to independent advice if required;

(v) alternative accommodation if required.

8.7.4 There should be clear procedures on what the child or member of staff should do if they feel that inappropriate or insufficient action has been taken.

8.7.5 Where abuse or neglect by a member of staff is suspected, normal child protection procedures should be instigated. Staff and management should cooperate fully with the investigation. The possibility of involvement and collusion of other members of staff must be recognised. Where such abuse is suspected, it will be necessary for An Garda Síochána and the HSE, when agreeing their strategy for investigation, to weigh the need for evidence carefully against the rights of the individual children concerned. 


\subsection{Children in the care of the State under the Child Care Act 1991}

8.8.1 Additional guidance is set out below in respect of children who are in the care of the State and who may be vulnerable to abuse.

\section{Foster/Relative care and Residential care}

8.8.2 The HSE Children and Family Services have responsibilities for children whom they place with relatives or with foster carers or in residential placements, as provided for in the Child Care Act 1991 and the Child Care Regulations 1995. In arranging, providing or supervising placements with foster/relative carers or in residential centres, the welfare of the child must be paramount. The wishes and feelings of the child and his or her parents should be taken into account.

8.8.3 The national standards developed for children in foster/relative care and for children in residential care should be readily available to children, foster/relative carers and their families, and to all HSE staff involved in the provision of these services (see Paragraph 8.3.1).

8.8.4 Children entering the care of the State under the Child Care Act 1991 may have previously been abused or neglected. Any allegation of abuse or neglect, past or present, must be dealt with sensitively and support provided to the child and others who have developed close relationships with that child, e.g. the foster carers and their family, other children in the residence.

8.8.5 When the HSE Children and Family Services are assessing the allegation of alleged abuse or neglect of children in foster care or in a residential centre, the safety of any other children in the house/centre should be considered.

\subsection{Other vulnerable children}

8.9.1 Research has shown that abuse of children with disabilities is a significant problem. The abuser is most likely to be known to the victim.

8.9.2 Parents, teachers and all staff in services for children with disabilities need to be familiar with the indicators of abuse and to be alert for signs of abuse.

8.9.3 All agencies/organisations working with children with disabilities should have clear guidelines for preventing, identifying and reporting child abuse or neglect and should ensure that staff and volunteers are trained in the use of the Children First: National Guidance.

8.9.4 Particular attention should be paid to the welfare and protection of children who are living apart from their birth parents and whose first language is not English.

8.9.5 An area of growing concern is where children and young people may be trafficked into this country for purposes of exploitation, either employment or sexual. These children may resist offers of assistance from the HSE due to fears for their own safety or that of their families. They are frequently hidden within communities since they do not attend educational, religious or social events.

\subsection{Children who are homeless}

8.10.1 Occasionally, children will come to the attention of the HSE whose circumstances are unclear and who, because of what may be temporary difficulties, are without accommodation. In such circumstances, the following actions should be taken by the HSE Children and Family Services in line with the Youth Homeless Strategy 2001:

(i) Establish with the child, in a manner appropriate to his or her age and stage of development, the circumstances in which he or she became homeless.

(ii) Assess the potential for the child to return to his or her family home, including whether family support is needed to achieve this. 
(iii) Assess the child's physical, social and psychological well-being, including the need for medical treatment or treatment for drug/alcohol problems.

(iv) Assess the short and longer term accommodation/care arrangements for the child if he or she is unable to return home.

8.10.2 If a return to the child's parents/carers is not considered the most appropriate action, an alternative temporary placement should be identified, with a family member or friend, which is acceptable to the parents/carers and the child, and agreed by them.

8.10.3 Where it is not possible to return a child who is not at home to his or her parents/carers or to find a temporary placement with relatives or friends, then the HSE Children and Family Services have three options:

(i) If circumstances warrant, the HSE may pursue an Emergency Care Order under the Child Care Act 1991.

(ii) There may be a voluntary reception of the child into the care of the HSE.

(iii) If grounds for receiving the child into care are not clear or do not exist and there appears to be no suitable accommodation for the child, then the HSE has an obligation to provide him or her with a place to stay which is suitable to his or her needs. This placement should be on an emergency or short-term basis, pending a full assessment.

8.10.4 Any concern about the care and protection of children who are homeless should be assessed in the same way as any other child protection concern. 


\section{Peer abuse}

\subsection{Purpose}

9.1.1 In some cases of child abuse, the alleged perpetrator will be another child. In such situations, it is particularly important to consider how the HSE Children and Family Services and other agencies can provide care for both the child victim and the child abuser. The purpose of this chapter is to provide guidance on the identification of and response to such cases.

\subsection{General guidelines}

9.2.1 In a situation where child abuse is alleged to have been carried out by another child, the child protection procedures should be adhered to for both the victim and the alleged abuser - i.e. it should be considered a child care and protection issue for both children.

9.2.2 Abusive behaviour that is perpetrated by children must be acted upon. If there is any conflict of interest between the welfare of the alleged abuser and the victim, the victim's welfare is of paramount importance.

9.2.3 As in all cases of child abuse, it is essential to respond to the needs of children who are abused by their peers. Each individual case will require its own unique intervention. Appropriate support and services should be provided to the child and his or her parents/carers as quickly as possible. In the case of child sexual abuse by peers, treatment approaches may include individual treatment and/or group therapy for the child or adolescent.

9.2.4 Children who are abusive towards other children also require comprehensive assessment and therapeutic intervention by skilled child care professionals. Treatment is more likely to be effective if begun early in the child's life.

It is known that some adult abusers begin abusing during childhood and adolescence, that significant numbers will have suffered abuse themselves and that the abuse is likely to become progressively more serious. Early referral and intervention is therefore essential.

9.2.5 Future abuse can be prevented if intervention takes place early in the child's life. Therefore, it is essential to refer concerns about peer abuse immediately to the HSE Children and Family Services. The HSE should establish appropriate treatment programmes to cater for children who engage in abusive behaviour with other children.

9.2.6 It should be anticipated that an allegation of peer abuse will have a detrimental impact on relationships between the alleged abuser, his or her parents/carers and other family members. A negative impact on other social relationships, such as with peers and neighbours, should also be anticipated. As a result, the child and family may experience isolation, and in some situations victimisation, following an allegation of abuse. The child's parents/carers will need support and advice to help them understand the abusive behaviour and to deal with the situation. Active participation and commitment by parents/carers can be an important factor in the success of treatment and may be crucial in influencing the general outcome of the case. It is therefore essential to provide adequate support services to the child and family throughout the assessment and treatment processes.

\subsection{Sexual abuse by children and young people}

9.3.1 Research shows that teenagers perpetrate a considerable proportion of child sexual abuse. Such cases should be referred to the HSE Children and Family Services. It is important that the different types of behaviour are clearly identified and that no young person is wrongly labelled 'a child abuser' without a clear analysis of the particular behaviour. Four categories of behaviour warrant attention: normal sexual exploration; abuse reactive behaviour; sexually obsessive behaviour; and abusive behaviour by adolescents and young people. 
9.3.2 Normal sexual exploration: This could consist of naive play between two children that involves the exploration of their sexuality. This type of behaviour may be prompted by exchanges between children, such as 'You show me yours and I'll show you mine'. One of the key aspects of this behaviour is its tone: there should not be any coercive or dominating aspects to this behaviour. Usually, there is no need for child protection intervention of any kind in this type of situation.

9.3.3 Abuse reactive behaviour: In this situation, one child who has been abused already acts out the same behaviour on another child. This is serious behaviour and needs to be treated as such. In addition to responding to the needs of the abused child, the needs of the child perpetrator in this situation must also be addressed.

9.3.4 Sexually obsessive behaviour: In this type of situation, the children may engage in sexually compulsive behaviour. An example of this would be excessive masturbation, which may well be meeting some other emotional need. Most children masturbate at some point in their lives. However, in families where care and attention is missing, they may have extreme comfort needs that are not being met and may move from masturbation to excessive interest or curiosity in sex, which takes on excessive or compulsive aspects. These children may not have been sexually abused, but they may be extremely needy and may require very specific help in addressing those needs.

9.3.5 Abusive behaviour by adolescents and young people: Behaviour that is abusive will have elements of domination, coercion or bribery, and certainly secrecy. The fact that the behaviour is carried out by an adolescent, for example, does not, in itself, make it 'experimentation'. However, if there is no age difference between the two children or no difference in status, power or intellect, then one could argue that this is indeed experimentation. On the other hand, if, for example, the adolescent is aged 13 and the child is aged 3, this gap in itself creates an abusive quality that should be taken seriously.

\subsection{Bullying}

9.4.1 Bullying can be defined as repeated aggression - whether it be verbal, psychological or physical - that is conducted by an individual or group against others. It is behaviour that is intentionally aggravating and intimidating, and occurs mainly among children in social environments such as schools. It includes behaviours such as teasing, taunting, threatening, hitting or extortion by one or more persons against a victim. Bullying can also take the form of racial abuse. With developments in modern technology, children can also be the victims of non-contact bullying, via mobile phones, the Internet and other personal devices.

9.4.2 Bullying of children can also be perpetrated by adults, including adults who are not related to the child. Bullying behaviour when perpetrated by adults, rather than children, could be regarded as physical or emotional abuse. However, other major forms of child abuse, such as neglect and sexual abuse, are not normally comprehended by the term 'bullying'.

\section{Bullying in schools}

9.4.3 It is recognised that bullying in schools is a particular problem. It is imperative that school management boards should have a policy in place to deal with bullying and that teachers are aware of this policy and of procedural guidelines to deal with it. In situations where the incident is serious and where the behaviour is regarded as potentially abusive, the school should consult the HSE Children and Family Services with a view to drawing up an appropriate response, such as a management plan.

9.4.4 In the first instance, it is the school authorities that are responsible for dealing with bullying in school. School authorities should exercise this responsibility by having regard to the existing advice and to the Guidelines on countering bullying behaviour in primary and post-primary schools from the Department of Education (1993).

9.4.5 Serious instances of bullying behaviour should be referred to the HSE Children and Family Services. 


\section{Training in child protection and welfare}

\subsection{Purpose}

10.1.1 The purpose of this chapter is to outline the role of training for effective child protection and the levels of training required for different types of staff in all organisations working with children. One of the core issues identified in child abuse enquiries is the breakdown in communication between disciplines and agencies. Accordingly, it is essential that training is provided on a multidisciplinary and interagency basis.

10.1.2 Training aims to promote effective interventions in the care and protection of children. Effective child protection depends on the skills, knowledge and values of personnel working with children and families, as well as cooperation between agencies (interagency) and within agencies (intra-agency). Relevant training and education is an essential prerequisite for achieving this. All agencies involved with children have a responsibility to ensure that such training is available on an ongoing basis.

10.1.3 For voluntary and community providers of services, regard should be had to Our Duty to Care: The principles of good practice for the protection of children and young people (Department of Health and Children, 2002) in the provision of child protection training for staff and volunteers.

\subsection{Objectives of child protection and welfare training}

10.2.1 Training in child protection and welfare has a number of objectives:

(i) to ensure that personnel are equipped with appropriate skills, knowledge and values to deliver an effective service to children;

(ii) to ensure that personnel are aware of relevant legislation, national guidelines and local child protection procedures and protocols;

(iii) to translate learning into a better service for children and families in collaboration with other service providers;

(iv) to strengthen relationships through interagency training.

\subsection{Approach to child protection and welfare training}

10.3.1 The level and type of training required depends on the degree of involvement that the staff of particular agencies have in child protection and welfare work. All relevant staff should be trained in the recognition of signs of abuse (see Chapter 2 and Appendix 1) and what immediate action to take (see Chapter 3).

10.3.2 A strategy for training in child protection and welfare must be developed in the HSE. This strategy will set out the training aims involved, learning outcomes, target groups, proposed initiatives, performance indicators and evaluation processes.

10.3.3 Training in child protection and welfare is required at two levels - basic and advanced - in order to meet the diversity of needs within the HSE and other organisations that provide services to children and families.

10.3.4 Basic-level training in child protection and welfare should aim to equip personnel with knowledge of the relevant child care legislation, national and local agency policies, procedures and protocols (as well as a knowledge of the local network within which they work) and skills in the use of these. Such basic training must be delivered on a multidisciplinary interagency basis so that the key learning that takes place results from discussion and the sharing of knowledge, experience and perspectives across disciplines and services. The target group for basic-level training in child protection and welfare should be personnel whose roles involve regular direct or indirect contact with children and families. 
10.3.5 Advanced-level training in child protection and welfare should aim to equip personnel with knowledge, skills and critical perspectives in specific areas of policy and practice, for example, risk assessment and working in partnership with parents/carers. Training should be appropriate to the person's professional role and, again, should be delivered on a multidisciplinary interagency basis. The target group for advanced-level training in child protection and welfare should be personnel whose core duties involve the supervision or practice of child protection and the provision of support services to children and families.

10.3.6 Training for managers: Training should be in place for managers of child protection services who have no direct professional expertise or experience in the area. The training should include an overview of child protection activity and interventions, the statutory responsibilities delegated within the HSE, the management functions of Children First and the information requirements of the manager in order to monitor and support good quality practice within the area. This training should assist with decisions relating to planning, resourcing, staffing, budgeting and management oversight.

\subsection{Target groups}

10.4.1 There are a number of key target groups for training in child protection and welfare. The first are staff in the HSE Children and Family Services and An Garda Síochána, by virtue of their statutory responsibility for child protection. The second are staff in a wide range of agencies, both statutory and non-statutory, who provide services to children and families and who have a social responsibility to safeguard the welfare of children. These include, among others, disability organisations, schools, GPs, pre-school services, sports clubs, faith-based institutions and other voluntary organisations.

10.4.2 Training is essential for professionals involved in front-line child protection work, such as social workers, public health nurses, medical doctors (especially GPs and staff in emergency departments) and Gardaí. Professionals also have a responsibility to see that they keep up to date with current developments in this area.

10.4.3 Child protection and welfare is a corporate responsibility of all employees of the HSE. The development of training strategies at HSE level must reflect this premise, with appropriate training at a multidisciplinary level.

\subsection{Interagency training}

10.5.1 Interdisciplinary and interagency cooperation is essential in order to promote the welfare of children. This is an essential element in the professional task of protecting children from abuse. All agencies involved with children should participate in interagency training programmes.

10.5.2 Training in child protection and welfare is also needed for residential care staff, foster carers and family support workers. Social work teams in the HSE are encouraged to support the development of interagency and multidisciplinary training for all staff engaged in child protection work and to provide places on their training courses for non-HSE staff.

10.5.3 All agencies should establish joint training programmes on child abuse issues, with access for all professional groups in direct contact with children and families. These programmes, preferably involving trainers from a variety of relevant agencies, should help to promote understanding of the respective roles of staff in each agency and thus promote effective working relationships.

10.5.4 A designated senior staff member in each agency or organisation should play a central role in developing, monitoring and evaluating training in child protection and welfare. Staff in all relevant agencies should be made aware of any training opportunities that exist and be encouraged to participate.

10.5.5 The management of schools, pre-school services and voluntary organisations must also ensure that personnel are trained in the recognition of signs of abuse (see Chapter 2 and Appendix 1) and on the standard reporting procedure (see Chapter 3). 
10.5.6 Front-line personnel in such services who meet the public, like telephonists and receptionists, should be given clear instructions on what action to take if contacted by anyone wishing to report suspected child abuse.

10.5.7 Training needs will change continuously and training in child protection and welfare must be an integral part of the plans in all agencies. A percentage of the annual budget in each agency should be explicitly committed to child protection training. An annual review of the training strategy for child protection and welfare should be undertaken.

10.5.8 Specialist training is required for selected HSE staff and members of An Garda Síochána who will be involved in the parallel investigation of cases and subsequent intervention (see Chapter 7). The aim of this training is to enable members of each service to understand fully each other's role, to learn how to work together on a joint basis and to learn how to interview children who may have been abused by adults (i.e. Specialist Interviewer Training under Section 16(1)(b) of the Criminal Evidence Act 1992). 


\section{References}

and Official Websites 


\section{References}

Colbourn Faller, K. (1989) Child Sexual Abuse. An Interdisciplinary Manual for Diagnosis Case Management and Treatment. Basingstoke: Macmillan.

Commission to Inquire into Child Abuse (2009) Report of the Commission to Inquire into Child Abuse, Volumes I-V. Available at: www.childabusecommission.ie

Department of Education (1993) Guidelines on countering bullying behaviour in primary and post-primary schools. Dublin: Government Publications.

Department of Education and Science (2001) Child Protection - Guidelines and Procedures. Dublin: Department of Education and Science.

Department of Education and Department of Health (1993) Child Abuse Prevention Programme. Dublin: Government Publications.

Department of Health (1987) Child Abuse Guidelines. Dublin: Government Publications.

Department of Health (1995) Garda Siochána - Health Board Guidelines. Dublin: Government Publications.

Department of Health (1995) Child Care (Placement of Children in Foster Care) Regulations, 1995.

Dublin: Government Publications.

Department of Health (1995) Child Care (Placement of Children in Residential Care) Regulations, 1995.

Dublin: Government Publications.

Department of Health (1995) Child Care (Placement of Children with Relatives) Regulations, 1995. Dublin: Government Publications.

Department of Health (1997) Putting Children First - Promoting and Protecting the Rights of Children. Dublin: Government Publications.

Department of Health and Children (1999) Children First: National Guidelines for the Protection and Welfare of Children (1st edition). Dublin: Government Publications.

Department of Health and Children (2000) The National Children's Strategy: Our Children - Their Lives. Dublin: Government Publications.

Department of Health and Children (2002) Our Duty to Care: The principles of good practice for the protection of children and young people. Dublin: Government Publications.

Department of the Taoiseach (1997) An Action Programme for the Millennium: A Programme for Government. Dublin: Government Publications. Available at: www.taoiseach.ie

Department of the Taoiseach (2002) Programme for Government. Dublin: Government Publications. Available at: www.taoiseach.ie

Department of the Taoiseach (2006) Towards 2016: Ten-Year Framework Social Partnership Agreement 2006-2015. Dublin: Government Publications. Available at: www.taoiseach.ie

Department of the Taoiseach (2007) Programme for Government. Dublin: Government Publications. Available at: www.taoiseach.ie

Dubowitz, Howard (1999) Neglected Children: Research, Practice and Policy. London: SAGE Publications.

Government of Ireland (1988) Data Protection Act. Dublin: Government Publications.

Government of Ireland (1991) Child Care Act. Dublin: Government Publications.

Government of Ireland (1996) Domestic Violence Act. Dublin: Government Publications.

Government of Ireland (1997) Freedom of Information Act. Dublin: Government Publications.

Government of Ireland (1997) Non-Fatal Offences against the Person Act. Dublin: Government Publications.

Government of Ireland (1998) Education Act. Dublin: Government Publications.

Government of Ireland (1998) Protections for Persons Reporting Child Abuse Act 1998. Dublin: Government Publications.

Government of Ireland (2001) Children Act. Dublin: Government Publications.

Government of Ireland (2007) Child Care (Amendment) Act. Dublin: Government Publications.

HIQA (2010) Guidance for the Health Service Executive for the Review of Serious Incidents, including deaths of children in care. Dublin: Health Information and Quality Authority. 
HSEA (2005) Trust in Care: Guidelines for Health Service Employers on preventing patient/dient abuse and dealing with allegations of abuse against employees. Dublin: Health Service Executive.

National Board for Safeguarding Children in the Catholic Church (2009) Safeguarding Children: Standards and Guidance Document for the Catholic Church in Ireland. Maynooth: National Board for Safeguarding Children in the Catholic Church in Ireland. Available at: www.safeguarding.ie

Ombudsman for Children's Office (2010) A report based on an investigation into the implementation of Children First, National Guidelines for the Protection and Welfare of Children. Dublin: Ombudsman for Children's Office. Available at: www.oco.ie

OMC (2007) The Agenda for Children's Services: A Policy Handbook, Office of the Minister for Children. Dublin: Government Publications. Available at: www.dcya.ie

OMCYA (2008) National Review of Compliance with Children First: National Guidelines for the Protection and Welfare of Children, Office of the Minister for Children and Youth Affairs. Dublin: Government Publications. Available at: www.dcya.ie

OMCYA (2009) Report of the Commission to Inquire into Child Abuse, 2009: Implementation Plan, Office of the Minister for Children and Youth Affairs. Dublin: Government Publications. Available at: www.dcya.ie

Skuse, D. (1989) 'Emotional Abuse and Neglect'. In: R. Meadow (ed.), ABC of Child Abuse. London: British Medical Journal Publications.

Skuse, D. and Bentovim, A. (1994) 'Physical and Emotional Maltreatment'. In: M. Rutter, E. Taylor and L. Hersor (eds.), Child and Adolescent Psychiatry (3rd edition). Oxford: Blackwell Scientific Publications.

UN (1989) United Nations Convention on the Rights of the Child. Geneva: United Nations Office of the High Commissioner for Human Rights. Available at: www2.ohchr.org/english/law/crc.htm

\section{Official websites}

An Garda Síochána

Department of Children and Youth Affairs

Department of Education and Skills

Department of Health

Department of Justice and Law Reform

Health Information and Quality Authority

Health Service Executive

Office of the Attorney General

Oireachtas of Ireland

Ombudsman for Children's Office

UN Office of the High Commissioner for Human Rights www.garda.ie

www.dcya.ie

www.education.ie

www.dohc.ie

www.justice.ie

www.hiqa.ie

www.hse.ie

www.attorneygeneral.ie

www.oireachtas.ie

www.oco.ie

www.ohchr.org 
Appendices 


\section{Appendix 1: Signs and symptoms of child abuse}

\section{Signs and symptoms of neglect}

Child neglect is the most common category of abuse. A distinction can be made between 'wilful' neglect and 'circumstantial' neglect. 'Wilful' neglect would generally incorporate a direct and deliberate deprivation by a parent/carer of a child's most basic needs, e.g. withdrawal of food, shelter, warmth, clothing, contact with others. 'Circumstantial' neglect more often may be due to stress/inability to cope by parents or carers.

Neglect is closely correlated with low socio-economic factors and corresponding physical deprivations. It is also related to parental incapacity due to learning disability, addictions or psychological disturbance.

The neglect of children is 'usually a passive form of abuse involving omission rather than acts of commission' (Skuse and Bentovim, 1994). It comprises 'both a lack of physical caretaking and supervision and a failure to fulfil the developmental needs of the child in terms of cognitive stimulation'.

Child neglect should be suspected in cases of:

- abandonment or desertion;

- children persistently being left alone without adequate care and supervision;

- malnourishment, lacking food, inappropriate food or erratic feeding;

- lack of warmth;

- lack of adequate clothing;

- inattention to basic hygiene;

- lack of protection and exposure to danger, including moral danger or lack of supervision appropriate to the child's age;

- persistent failure to attend school;

- non-organic failure to thrive, i.e. child not gaining weight due not only to malnutrition but also to emotional deprivation;

- failure to provide adequate care for the child's medical and developmental problems;

- exploited, overworked.

\section{Characteristics of neglect}

Child neglect is the most frequent category of abuse, both in Ireland and internationally. In addition to being the most frequently reported type of abuse; neglect is also recognised as being the most harmful. Not only does neglect generally last throughout a childhood, it also has long-term consequences into adult life. Children are more likely to die from chronic neglect than from one instance of physical abuse. It is well established that severe neglect in infancy has a serious negative impact on brain development.

Neglect is associated with, but not necessarily caused by, poverty. It is strongly correlated with parental substance misuse, domestic violence and parental mental illness and disability.

Neglect may be categorised into different types (adapted from Dubowitz, 1999):

- Disorganised/chaotic neglect: This is typically where parenting is inconsistent and is often found in disorganised and crises-prone families. The quality of parenting is inconsistent, with a lack of certainty and routine, often resulting in emergencies regarding accommodation, finances and food. This type of neglect results in attachment disorders, promotes anxiety in children and leads to disruptive and attention-seeking behaviour, with older children proving more difficult to control and discipline. The home may be unsafe from accidental harm, with a high incident of accidents occurring.

- Depressed or passive neglect: This type of neglect fits the common stereotype and is often characterised by bleak and bare accommodation, without material comfort, and with poor hygiene and little if any social and psychological stimulation. The household will have few toys and those that are there may be broken, dirty or inappropriate for age. Young children will spend long periods in cots, playpens or pushchairs. There is often a lack of food, inadequate bedding and no clean clothes. There can be a sense of hopelessness, coupled with ambivalence about improving the household situation. In such environments, children frequently are absent from school and have poor homework routines. Children subject to these circumstances are at risk of major developmental delay.

- Chronic deprivation: This is most likely to occur where there is the absence of a key attachment figure. It is most often found in large institutions where infants and children may be physically well cared for, but where there is no opportunity to form an attachment with an individual carer. In these situations, children are dealt with by a range of adults and their needs are seen as part of the demands of a group of children. This form of deprivation will also be associated with poor stimulation and can result in serious developmental delays. 
The following points illustrate the consequences of different types of neglect for children:

- inadequate food - failure to develop;

- household hazards - accidents;

- lack of hygiene - health and social problems;

- lack of attention to health - disease;

- inadequate mental health care - suicide or delinquency;

- inadequate emotional care - behaviour and educational

- inadequate supervision - risk-taking behaviour;

- unstable relationship - attachment problems;

- unstable living conditions - behaviour and anxiety, risk of accidents;

- exposure to domestic violence - behaviour, physical and mental health;

- community violence - anti social behaviour.

\section{Signs and symptoms of emotional neglect and abuse}

Emotional neglect and abuse is found typically in a home lacking in emotional warmth. It is not necessarily associated with physical deprivation. The emotional needs of the children are not met; the parent's relationship to the child may be without empathy and devoid of emotional responsiveness.

Emotional neglect and abuse occurs when adults responsible for taking care of children are unaware of and unable (for a range of reasons) to meet their children's emotional and developmental needs. Emotional neglect and abuse is not easy to recognise because the effects are not easily observable. Skuse (1989) states that 'emotional abuse refers to the habitual verbal harassment of a child by disparagement, criticism, threat and ridicule, and the inversion of love, whereby verbal and non-verbal means of rejection and withdrawal are substituted'.

Emotional neglect and abuse can be identified with reference to the indices listed below. However, it should be noted that no one indicator is conclusive of emotional abuse. In the case of emotional abuse and neglect, it is more likely to impact negatively on a child where there is a cluster of indices, where these are persistent over time and where there is a lack of other protective factors.

- rejection;

- lack of comfort and love;

- lack of attachment;

- lack of proper stimulation (e.g. fun and play);

- lack of continuity of care (e.g. frequent moves, particularly unplanned);

- continuous lack of praise and encouragement;

- serious over-protectiveness;

- inappropriate non-physical punishment (e.g. locking in bedrooms);

- family conflicts and/or violence;

- every child who is abused sexually, physically or neglected is also emotionally abused;

- inappropriate expectations of a child relative to his/her age and stage of development.

Children who are physically and sexually abused and neglected also suffer from emotional abuse.

\section{Signs and symptoms of physical abuse}

Unsatisfactory explanations, varying explanations, frequency and clustering for the following events are high indices for concern regarding physical abuse:

- bruises (see below for more detail);

- fractures;

- swollen joints;

- burns/scalds (see below for more detail);

- abrasions/lacerations;

- haemorrhages (retinal, subdural);

- damage to body organs;

- poisonings - repeated (prescribed drugs, alcohol);

- failure to thrive;

- coma/unconsciousness;

- death.

There are many different forms of physical abuse, but skin, mouth and bone injuries are the most common. 


\section{Bruises}

\section{Accidental}

Accidental bruises are common at places on the body where bone is fairly close to the skin. Bruises can also be found towards the front of the body, as the child usually will fall forwards.

Accidental bruises are common on the chin, nose, forehead, elbow, knees and shins. An accident-prone child can have frequent bruises in these areas. Such bruises will be diffuse, with no definite edges. Any bruising on a child before the age of mobility must be treated with concern.

\section{Non-accidental}

Bruises caused by physical abuse are more likely to occur on soft tissues, e.g. cheek, buttocks, lower back, back, thighs, calves, neck, genitalia and mouth.

Marks from slapping or grabbing may form a distinctive pattern. Slap marks might occur on buttocks/cheeks and the outlining of fingers may be seen on any part of the body. Bruises caused by direct blows with a fist have no definite pattern, but may occur in parts of the body that do not usually receive injuries by accident. A punch over the eye (black eye syndrome) or ear would be of concern. Black eyes cannot be caused by a fall on to a flat surface. Two black eyes require two injuries and must always be suspect. Other distinctive patterns of bruising may be left by the use of straps, belts, sticks and feet. The outline of the object may be left on the child in a bruise on areas such as the back or thighs (areas covered by clothing).

Bruises may be associated with shaking, which can cause serious hidden bleeding and bruising inside the skull. Any bruising around the neck is suspicious since it is very unlikely to be accidentally acquired.. Other injuries may feature - ruptured eardrum/fractured skull. Mouth injury may be a cause of concern, e.g. torn mouth (frenulum) from forced bottle-feeding.

\section{Bone injuries}

Children regularly have accidents that result in fractures. However, children's bones are more flexible than those of adults and the children themselves are lighter, so a fracture, particularly of the skull, usually signifies that considerable force has been applied.

\section{Non-accidental}

A fracture of any sort should be regarded as suspicious in a child under 8 months of age. A fracture of the skull must be regarded as particularly suspicious in a child under 3 years. Either case requires careful investigation as to the circumstances in which the fracture occurred. Swelling in the head or drowsiness may also indicate injury.

\section{Burns}

Children who have accidental burns usually have a hot liquid splashed on them by spilling or have come into contact with a hot object. The history that parents give is usually in keeping with the pattern of injury observed. However, repeated episodes may suggest inadequate care and attention to safety within the house.

\section{Non-accidental}

Children who have received non-accidental burns may exhibit a pattern that is not adequately explained by parents. The child may have been immersed in a hot liquid. The burn may show a definite line, unlike the type seen in accidental splashing. The child may also have been held against a hot object, like a radiator or a ring of a cooker, leaving distinctive marks. Cigarette burns may result in multiple small lesions in places on the skin that would not generally be exposed to danger. There may be other skin conditions that can cause similar patterns and expert paediatric advice should be sought.

\section{Bites}

Children can get bitten either by animals or humans. Animal bites (e.g. dogs) commonly puncture and tear the skin, and usually the history is definite. Small children can also bite other children.

\section{Non-accidental}

It is sometimes hard to differentiate between the bites of adults and children since measurements can be inaccurate. Any suspected adult bite mark must be taken very seriously. Consultant paediatricians may liaise with dental colleagues in order to identify marks correctly.

\section{Poisoning}

Children may commonly take medicines or chemicals that are dangerous and potentially life-threatening. Aspects of care and safety within the home need to be considered with each event. 


\section{Non-accidental}

Non-accidental poisoning can occur and may be difficult to identify, but should be suspected in bizarre or recurrent episodes and when more than one child is involved. Drowsiness or hyperventilation may be a symptom.

\section{Shaking violently}

Shaking is a frequent cause of brain damage in very young children.

\section{Fabricated/induced illness}

This occurs where parents, usually the mother (according to current research and case experience), fabricate stories of illness about their child or cause physical signs of illness. This can occur where the parent secretly administers dangerous drugs or other poisonous substances to the child or by smothering. The symptoms that alert to the possibility of fabricated/induced illness include:

(i) symptoms that cannot be explained by any medical tests; symptoms never observed by anyone other than the parent/carer; symptoms reported to occur only at home or when a parent/carer visits a child in hospital;

(ii) high level of demand for investigation of symptoms without any documented physical signs;

(iii) unexplained problems with medical treatment, such as drips coming out or lines being interfered with; presence of unprescribed medication or poisons in the blood or urine.

\section{Signs and symptoms of sexual abuse}

Child sexual abuse often covers a wide spectrum of abusive activities. It rarely involves just a single incident and usually occurs over a number of years. Child sexual abuse most commonly happens within the family.

Cases of sexual abuse principally come to light through:

(a) disclosure by the child or his or her siblings/friends;

(b) the suspicions of an adult;

(c) physical symptoms.

Colburn Faller (1989) provides a description of the wide spectrum of activities by adults which can constitute child sexual abuse. These include:

\section{Non-contact sexual abuse}

- 'Offensive sexual remarks', including statements the offender makes to the child regarding the child's sexual attributes, what he or she would like to do to the child and other sexual comments.

- Obscene phone calls.

- Independent 'exposure' involving the offender showing the victim his/her private parts and/or masturbating in front of the victim.

- 'Voyeurism' involving instances when the offender observes the victim in a state of undress or in activities that provide the offender with sexual gratification. These may include activities that others do not regard as even remotely sexually stimulating.

\section{Sexual contact}

- Involving any touching of the intimate body parts. The offender may fondle or masturbate the victim, and/or get the victim to fondle and/or masturbate them. Fondling can be either outside or inside clothes. Also includes 'frottage', i.e. where offender gains sexual gratification from rubbing his/her genitals against the victim's body or clothing.

\section{Oral-genital sexual abuse}

- Involving the offender licking, kissing, sucking or biting the child's genitals or inducing the child to do the same to them.

\section{Interfemoral sexual abuse}

- Sometimes referred to as 'dry sex' or 'vulvar intercourse', involving the offender placing his penis between the child's thighs.

\section{Penetrative sexual abuse, of which there are four types:}

- 'Digital penetration', involving putting fingers in the vagina or anus, or both. Usually the victim is penetrated by the offender, but sometimes the offender gets the child to penetrate them.

- 'Penetration with objects', involving penetration of the vagina, anus or occasionally mouth with an object.

- 'Genital penetration', involving the penis entering the vagina, sometimes partially.

- 'Anal penetration' involving the penis penetrating the anus. 


\section{Sexual exploitation}

- Involves situations of sexual victimisation where the person who is responsible for the exploitation may not have direct sexual contact with the child. Two types of this abuse are child pornography and child prostitution.

- 'Child pornography' includes still photography, videos and movies, and, more recently, computer-generated pornography.

- 'Child prostitution' for the most part involves children of latency age or in adolescence. However, children as young as 4 and 5 are known to be abused in this way.

The sexual abuses described above may be found in combination with other abuses, such as physical abuse and urination and defecation on the victim. In some cases, physical abuse is an integral part of the sexual abuse; in others, drugs and alcohol may be given to the victim.

It is important to note that physical signs may not be evident in cases of sexual abuse due to the nature of the abuse and/or the fact that the disclosure was made some time after the abuse took place.

Carers and professionals should be alert to the following physical and behavioural signs:

- bleeding from the vagina/anus;

- difficulty/pain in passing urine/faeces;

- an infection may occur secondary to sexual abuse, which may or may not be a definitive sexually transmitted disease. Professionals should be informed if a child has a persistent vaginal discharge or has warts/rash in genital area;

- noticeable and uncharacteristic change of behaviour;

- hints about sexual activity;

- age-inappropriate understanding of sexual behaviour;

- inappropriate seductive behaviour;

- sexually aggressive behaviour with others;

- uncharacteristic sexual play with peers/toys;

- unusual reluctance to join in normal activities that involve undressing, e.g. games/swimming.

Particular behavioural signs and emotional problems suggestive of child abuse in young children (aged 0-10 years) include:

- mood change where the child becomes withdrawn, fearful, acting out;

- lack of concentration, especially in an educational setting;

- bed wetting, soiling;

- $\quad$ pains, tummy aches, headaches with no evident physical cause;

- skin disorders;

- reluctance to go to bed, nightmares, changes in sleep patterns;

- school refusal;

- separation anxiety;

- loss of appetite, overeating, hiding food.

Particular behavioural signs and emotional problems suggestive of child abuse in older children (aged 10+ years) include:

- depression, isolation, anger;

- running away;

- drug, alcohol, solvent abuse;

- self-harm;

- suicide attempts;

- missing school or early school leaving;

- eating disorders.

All signs/indicators need careful assessment relative to the child's circumstances. 


\section{Appendix 2: National contacts for HSE Children and Family Services}

\section{Also listed on HSE website (www.hse.ie/go/socialworkers) and from HSE LoCall Tel. 1850 241850. These contact numbers may be updated from time to time. Please check HSE website for latest information.}

\begin{tabular}{|c|c|c|}
\hline HSE Area & Address & Telephone No. \\
\hline DUBLIN NORTH & Health Centre, Cromcastle, Coolock, Dublin 5 & $\begin{array}{l}(01) 8164200 \\
(01) 8164244\end{array}$ \\
\hline $\begin{array}{l}\text { DUBLIN NORTH } \\
\text { CENTRAL }\end{array}$ & $\begin{array}{l}\text { Social Work Office, } 22 \text { Mountjoy Square, Dublin } 1 \\
\text { Social Work Office, Ballymun Health Centre, Dublin } 11\end{array}$ & $\begin{array}{l}(01) 8772300 \\
(01) 8467236\end{array}$ \\
\hline DUBLIN NORTH WEST & $\begin{array}{l}\text { Health Centre, Wellmount Park, Finglas, Dublin } 11 \\
\text { Social Work Department, Rathdown Road, Dublin } 7\end{array}$ & $\begin{array}{l}(01) 8567704 \\
(01) 8825000\end{array}$ \\
\hline DUBLIN SOUTH EAST & Social Work Department, Vergemount Hall, Clonskeagh, Dublin 6 & $\begin{array}{l}\text { (01) } 2680320 \\
(01) 2680333\end{array}$ \\
\hline DUBLIN SOUTH CITY & $\begin{array}{l}\text { Duty Social Work Carnegie Centre, 21-25 Lord Edward Street, Dublin } 2 \\
\text { Public Health Nursing, 21-25 Lord Edward Street, Dublin } 2 \\
\text { Family Support Service, 78B Church House, Donore Avenue, Dublin } 8\end{array}$ & $\begin{array}{l}(01) 6486555 \\
(01) 6486730 \\
(01) 4164441\end{array}$ \\
\hline DUBLIN SOUTH WEST & Milbrook Lawn, Tallaght, Dublin 24 & $\begin{array}{l}(01) 4520666 \\
(01) 4275000\end{array}$ \\
\hline DUBLIN WEST & $\begin{array}{l}\text { Social Work Department, Bridge House, Cherry Orchard Hospital, Ballyfermot, } \\
\text { Dublin } 10\end{array}$ & (01) 6206387 \\
\hline DUBLIN SOUTH & $\begin{array}{l}\text { Social Work Department, Our Lady's Clinic, Patrick Street, Dun Laoghaire, } \\
\text { Co. Dublin }\end{array}$ & (01) 6637300 \\
\hline CARLOW & $\begin{array}{l}\text { Carlow Social Work Office, Ground Floor, St. Dympna's Hospital, Athy Road, } \\
\text { Co. Carlow }\end{array}$ & (059) 9136587 \\
\hline CAVAN & HSE Community Child and Family Services, Drumalee Cross, Co. Cavan & $\begin{array}{l}049) 4377305 \\
(049) 4377306 \\
\end{array}$ \\
\hline CLARE & $\begin{array}{l}\text { Clare Duty Social Worker, River House, Gort Road, Ennis, Co. Clare } \\
\text { Social Work Department, Shannon Health Centre, Shannon, Co. Clare } \\
\text { Social Work Department, Kilrush Health Centre, Kilrush, Co. Clare }\end{array}$ & $\begin{array}{l}(065) 6863935 \\
(\text { Mon - Fri, 2pm - 5pm) } \\
(061) 718400 \\
(065) 9054200\end{array}$ \\
\hline CORK & $\begin{array}{l}\text { North Cork Social Work Department, } 134 \text { Bank Place, Mallow, Co. Cork } \\
\text { North Lee Child Lee Social Work Department, (adjacent to Shopping Centre), } \\
\text { Blackpool, Co. Cork } \\
\text { South Lee Social Work Department, St. Finbarr's Hospital, Douglas Road, Cork } \\
\text { West Cork Social Work Department, Coolnagarrane, Skibbereen, Co. Cork }\end{array}$ & $\begin{array}{l}(022) 54100 \\
(021) 4927000 \\
(021) 4923001 \\
(028) 40447\end{array}$ \\
\hline DONEGAL & $\begin{array}{l}\text { Links Business Centre, Lisfannon, Buncrana, Co. Donegal (East Team) } \\
\text { Euro House, Killybegs Road, Donegal, Co. Donegal (West Team) } \\
\text { Social Work Department, Millennium Court, Pearse Road, Letterkenny, } \\
\text { Co. Donegal (East Central Team and West Central Team) }\end{array}$ & $\begin{array}{l}(074) 9320420 \\
(074) 9723540 \\
(074) 9123672 \\
(074) 9123770\end{array}$ \\
\hline GALWAY & $\begin{array}{l}\text { Galway City, Social Work Department, Local Health Office, } 25 \text { Newcastle Road, } \\
\text { Galway, Co. Galway } \\
\text { Galway County, Tuam Social Work Department, Health Centre, Vicar Street, } \\
\text { Tuam, Co. Galway } \\
\text { Loughrea Social Work Department, Health Centre, Loughrea, Co. Galway } \\
\text { Ballinasloe Social Work Department, Health Centre, Brackernagh, Ballinasloe, } \\
\text { Co. Galway } \\
\text { Oughterard Social Work Department, Health Centre, Oughterard, Co. Galway }\end{array}$ & $\begin{array}{l}(091) 546366 \\
(093) 37200 \\
(091) 847820 \\
(090) 9646200 \\
(091) 552200\end{array}$ \\
\hline
\end{tabular}




\begin{tabular}{|c|c|c|}
\hline KERRY & $\begin{array}{l}\text { Social Work Department, HSE Community Services, Rathass, Tralee, Co. Kerry } \\
\text { Killarney Social Work Department, St. Margaret's Road, Killarney, Co. Kerry }\end{array}$ & $\begin{array}{l}(066) 7121566 \\
(064) 6636030\end{array}$ \\
\hline KILDARE & Social Work Department, St Mary's Craddockstown Road, Naas, Co. Kildare & $\begin{array}{l}(045) 873200 \\
(045) 882400\end{array}$ \\
\hline KILKENNY & $\begin{array}{l}\text { Social Work Office - Child Care Department, Child Youth and Families, } \\
\text { Carlow/Kilkenny, HSE South, St. Canice's Hospital, Dublin Road, Kilkenny, } \\
\text { Co. Kilkenny }\end{array}$ & $\begin{array}{l}(056) 7784057 \\
(056) 7784532\end{array}$ \\
\hline LIMERICK & $\begin{array}{l}\text { Social Work Department, Ballynanty Health Centre, Ballynanty, Limerick } \\
\text { (East Team), Co. Limerick } \\
\text { Social Work Department Roxtown Health Centre, Roxtown Terrace, Old Clare } \\
\text { Street, Limerick (East Team), Co. Limerick } \\
\text { Parkbeg Social Work Department, Parkbeg House, } 2 \text { Elm Drive, Caherdavin } \\
\text { Lawns, Ennis Road, Limerick, Co. Limerick } \\
\text { Social Work Department, Southill Health Centre, O'Malley Park, Southill, } \\
\text { Limerick, Co. Limerick } \\
\text { Newcastlewest Social Work Department, Newcastlewest Health Centre, } \\
\text { Newcastle West, Co. Limerick. }\end{array}$ & $\begin{array}{l}(061) 457100 \\
(061) 417622 \\
(061) 483091 \\
(061) 206820 \\
(061) 209985 \\
(069) 62155\end{array}$ \\
\hline LAOIS & Social Work Department, Child and Family Centre, Portlaoise, Co. Laois & $\begin{array}{l}(057) 8692567 \\
(057) 8692568\end{array}$ \\
\hline LEITRIM & $\begin{array}{l}\text { Social Work Department, Community Care Office, Leitrim Road, } \\
\text { Carrick on Shannon, Co. Leitrim }\end{array}$ & (071) 9650324 \\
\hline LONGFORD & Social Work Department, Tivoli House, Dublin Road, Co. Longford & (043) 3350584 \\
\hline LOUTH & $\begin{array}{l}\text { Social Work Department, Local Health Care Unit, Wilton House, Stapleton } \\
\text { Place, Dundalk, Co. Louth } \\
\text { Ballsgrove Health Centre, Ballsgrove, Drogheda, Co. Louth }\end{array}$ & $\begin{array}{l}(042) 9392200 \\
(041) 9838574 \\
(041) 9833163\end{array}$ \\
\hline MAYO & $\begin{array}{l}\text { Ballina Social Work Team, Ballina Health Centre, Mercy Road, Ballina, } \\
\text { Co. Mayo } \\
\text { Castlebar Social Work Team, St. Mary's Headquarters, Castlebar, Co. Mayo } \\
\text { Swinford Social Work Team, Swinford Health Centre, Aras Attracta, Swinford, } \\
\text { Co. Mayo }\end{array}$ & $\begin{array}{l}(096) 21511 \\
(096) 24841 \\
(094) 9022283 \\
(094) 9050133\end{array}$ \\
\hline MEATH & $\begin{array}{l}\text { Community Social Work Services, Enterprise Centre, Navan, Co. Meath } \\
\text { Community Social Work Services, Child and Family Centre, Navan, Co. Meath } \\
\text { Community Social Work Services, Dunshaughlin Health Care Unit, } \\
\text { Dunshaughlin, Co. Meath }\end{array}$ & $\begin{array}{l}(046) 9097817 \\
(046) 9078830 \\
(01) 8024102\end{array}$ \\
\hline MONAGHAN & Social Work Department, Local Health Care Unit, Rooskey, Co. Monaghan & $\begin{array}{l}(047) 30426 \\
(047) 30427\end{array}$ \\
\hline OFFALY & $\begin{array}{l}\text { Social Work Department, Derry Suite, Castlebuildings, Tara Street, Tullamore, } \\
\text { Co. Offaly }\end{array}$ & (057) 9370700 \\
\hline ROSCOMMON & $\begin{array}{l}\text { Social Work Team, Abbeytown House, Abbey Street, Roscommon, } \\
\text { Co. Roscommon } \\
\text { Social Work Team, Roscommon PCCC, Lanesboro' Road, Roscommon, } \\
\text { Co. Roscommon (Roscommon Area) } \\
\text { Social Work Team, Health Centre, Elphin Street, Boyle, Co. Roscommon } \\
\text { (Boyle Area) } \\
\text { Social Work Team, New HSE Offices, Knockroe, Castlerea, Co. Roscommon } \\
\text { (Castlerea Area) }\end{array}$ & $\begin{array}{l}\text { (090) } 6626732 \\
(090) 6637528 \\
(090) 6637529 \\
(071) 9662087 \\
(090) 6637851 \\
(090) 6637842\end{array}$ \\
\hline
\end{tabular}




\begin{tabular}{|c|c|c|}
\hline SLIGO & $\begin{array}{l}\text { Sligo Town and surrounding areas: Markievicz House, Barrack Street, Sligo, } \\
\text { Co. Sligo } \\
\text { South County Sligo: One Stop Shop, Teach Laighne, Humbert Street, } \\
\text { Tubercurry, Co. Sligo }\end{array}$ & $\begin{array}{l}\text { (071) } 9155133 \\
(071) 9120062\end{array}$ \\
\hline NORTH TIPPERARY & $\begin{array}{l}\text { North Tipperary Duty Social Work Team, Civic Offices, Limerick Road, Nenagh, } \\
\text { Co. Tipperary } \\
\text { North Tipperary Child Protection Services: Social Work Department, Annbrook, } \\
\text { Nenagh, Co. Tipperary } \\
\text { St. Mary's Health Centre, Parnell Street, Thurles, Co. Tipperary }\end{array}$ & $\begin{array}{l}(067) 46636 \\
(067) 41934 \\
(0504) 24609\end{array}$ \\
\hline SOUTH TIPPERARY & $\begin{array}{l}\text { South Tipperary Child Protection Services: Social Work Team, South Tipperary } \\
\text { Community Care Services, Western Road, Clonmel, } \\
\text { Co. Tipperary }\end{array}$ & $\begin{array}{l}\text { (052) } 6177302 \\
(052) 6177303\end{array}$ \\
\hline WATERFORD & $\begin{array}{l}\text { Waterford: Social Work Service, Waterford Community Services, Cork Road, } \\
\text { Co. Waterford } \\
\text { Dungarvan and surrounding areas: Social Work Department, Dungarvan } \\
\text { Community Services, St. Joseph's Hospital, Dungarvan, Co. Waterford }\end{array}$ & $\begin{array}{l}(051) 842827 \\
(058) 20906\end{array}$ \\
\hline WESTMEATH & $\begin{array}{l}\text { Social Work Department, Athlone Health Centre, Coosan Road, Athlone, } \\
\text { Co. Westmeath } \\
\text { Social Work Department, Child and Family Centre, St. Loman's, Springfield, } \\
\text { Mullingar, Co. Westmeath }\end{array}$ & $\begin{array}{l}(090) 6483106 \\
(044) 9344877\end{array}$ \\
\hline WEXFORD & $\begin{array}{l}\text { Gorey Health Centre, Hospital Grounds, Gorey, Co. Wexford } \\
\text { Enniscorthy Health Centre, Millpark Road, Enniscorthy, Co. Wexford } \\
\text { New Ross Health Centre, Hospital Grounds, New Ross, Co. Wexford } \\
\text { Social Work Department, Ely House, Ferrybank, Co. Wexford }\end{array}$ & $\begin{array}{l}\text { (053) } 9430100 \\
(053) 9233465 \\
\text { Contact through } \\
\text { Ely House below } \\
\text { (053) } 9123522 \text { Ext. } 201\end{array}$ \\
\hline WICKLOW & $\begin{array}{l}\text { Social Work Department, HSE Glenside Road, Wicklow Town, Co. Wicklow } \\
\text { Bray: Social Work Department, The Civic Centre, Main Street, Bray, } \\
\text { Co. Wicklow } \\
\text { Delgany: Social Work Department, Delgany Health Centre, Delgany, } \\
\text { Co. Wicklow }\end{array}$ & $\begin{array}{l}(0404) 60800 \\
(01) 2744180 \\
(01) 2744100 \\
(01) 2871482\end{array}$ \\
\hline
\end{tabular}




\section{Appendix 3: STANDARD REPORT FORM}

for reporting child protection and/or welfare concerns to the HSE

FORM NUMBER: CC01:01:00

STANDARD REPORT FORM

(For reporting CP\&W Concerns to HSE)

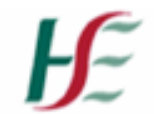

follmeanuds a Seithilise Silne Bealth Service Everitive

A. To Principal Social Worker/Designate:

1. Date of Report

2. Details of Child

\begin{tabular}{|l|l|l|r|r|}
\hline Name: & \multicolumn{1}{|c|}{ Male } & $\square$ & Female \\
\hline Address: & DOB & Age \\
\hline Alias & School & \\
\hline
\end{tabular}

3. Details of Persons Reporting Concern(s)

\begin{tabular}{l|l|l|}
\hline Name: & \multicolumn{1}{|l|}{ Telephone No. } \\
\hline Address: & Occupation: \\
\cline { 3 - 4 } & & Relationship to client: \\
\hline \multirow{2}{*}{ Reporter wishes to remain anonymous } & $\square$ & Reporter discussed with parents/guardians \\
\hline
\end{tabular}

\section{Parents Aware of Report}

Are the child's parents/carers aware that this concern is being reported to the HSE?

\section{Details of Report}

(Details of concern(s), allegation(s) or incident(s) dates, times, who was present, description of any observed injuries, parent's view(s), child's view(s) if known.) 
FORM NUMBER: CC01:01:00

STANDARD REPORT FORM (For reporting CP\&W Concerns to HSE)

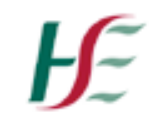

fodhmeanadt as Seirbhise Stint: Ileallh Senice Fecutive

\section{Relationships}

\section{Details of Mother}

Name:

Address:

(if different to child)

Telephone Nos.

\section{Details of Father}

Name:

Address:

(if different to child)

Telephone Nos.

\section{Household composition}

\begin{tabular}{|l|l|l|l|}
\hline Name & Relationship & DOB & $\begin{array}{c}\text { Additional information, } \\
\text { e.g. school/occupation/other }\end{array}$ \\
\hline & & & \\
\hline & & & \\
\hline & & \\
\hline
\end{tabular}

8. Name and Address of other personnel or agencies involved with this child:

\begin{tabular}{|l|l|l|}
\hline \multicolumn{1}{|c|}{ Name } & \multicolumn{1}{c|}{ Address } \\
\hline Social Worker & & \\
\hline PHN & & \\
\hline GP & & \\
\hline Hospital & & \\
\hline School & & \\
\hline Gardaí & & \\
\hline Pre-School/Crèche/YG & & \\
\hline Other (specify): & & \\
\hline
\end{tabular}

9. Details of person(s) allegedly causing concern in relation to the child

\begin{tabular}{|l|l|l|l|l|l|l|}
\hline Relationship to child: & Age & Male & $\square$ & Female \\
\hline Name: & Occupation: & & \\
\hline Address: & & & & \\
\hline
\end{tabular}

10. Details of person completing form

Name:

Occupation:

Signed

Date: 


\section{Guidance Notes}

The HSE has a statutory responsibility under the Child Care Act 1991 to promote the protection and welfare of children. The HSE therefore has an obligation to receive information about any child who is not receiving adequate care and/or protection.

This Report Form is for use by:

- Any professional, individual or group involved in services to children, including HSE personnel, who becomes aware of a child protection or welfare concern, or to whom a child protection or child welfare concern is reported.

- Professionals and individuals in the provision of child care services in the community who have service contracts with the HSE.

- Designated persons in a voluntary or community agency.

Please fill in as much information and detail as is known to you. This will assist the Social Work Department in assessing the level of risk to the child or the support services required. If the information requested is not known to you, please indicate this by putting a line through the question. It is likely that a social worker will contact you to discuss your report.

The HSE aims to work in partnership with parents. If you are making this report in confidence, you should note that the HSE cannot guarantee absolute confidentiality for the following reasons:

- A Court could order that information be disclosed.

- Under the Freedom of Information Act 1997, the Freedom of Information Commissioner may order that information be disclosed.

You should also note that in making a 'bona fide report', you are protected under the Protections for Persons Reporting Child Abuse Act 1998.

If you are unsure if you should report your concerns, please telephone the HSE duty social worker and discuss your concerns with them (see Appendix 2 for a full list of HSE offices nationwide). 
Appendix 4:

STANDARD NOTIFICATION FORM for use by the HSE in notifying cases to An Garda Siochána

\section{CONFIDENTIAL}

HSE Local Health Office Area

Address

\section{To: Superintendent}

Garda Síochána

Address

Ref. No.

\section{NOTIFICATION OF SUSPECTED CHILD ABUSE}

Child's Name

D.O.B.

Sex

Address

Father's Name

Mother's Name

1. The above named child has come to notice as a possible victim of child abuse.

2. Form(s) of abuse suspected:

$\square$ Neglect $\square$ Physical Abuse $\square$ Emotional Abuse* $\square$ Sexual Abuse

* All abuse involves an element of emotional ill-treatment; this category should be used where it is the main or sole form of abuse suspected.

3. Additional information

The Designated Social Worker dealing with this matter is:

Name Tel. No.

Address

Signed

Date

Designated Officer

RETURN SLIP (to be returned to relevant HSE Local Health Office Area)

Garda

Garda Ref. No.

Address

Child's Name

I acknowledge receipt of your notification.

The Designated Garda assigned to this case is:

Name

Tel. No.

Address Signed 


\section{Appendix 5:}

STANDARD NOTIFICATION FORM for use by An Garda Siochána in notifying cases to the HSE

\section{CONFIDENTIAL}

Garda Síochána Ref. No. Address

\section{To: Designated Officer}

HSE Local Health Office Area Address

\section{NOTIFICATION OF SUSPECTED CHILD ABUSE}

Child's Name

D.O.B. Sex

Address

Father's Name Mother's Name

1. The above named child has come to notice as a possible victim of child abuse.

2. Form(s) of abuse suspected:

$\square$ Neglect $\square$ Physical Abuse $\square$ Emotional Abuse* $\square$ Sexual Abuse

* All abuse involves an element of emotional ill-treatment; this category should be used where it is the main or sole form of abuse suspected.

3. Additional information

The Designated Garda dealing with this matter is:

Name

Address

Signed

Designated Officer
Tel. No.

Date

RETURN SLIP (to be returned to relevant Garda Station)

HSE Local Health Office Area

HSE Local Health Office Area Ref. No.

Address

Child's Name

I acknowledge receipt of your notification.

The Designated Social Worker allocated to this case is:

Name

Tel. No.

Address

Signed 
Appendix 6:

RECORD OF GARDA - HSE LIAISON FORM
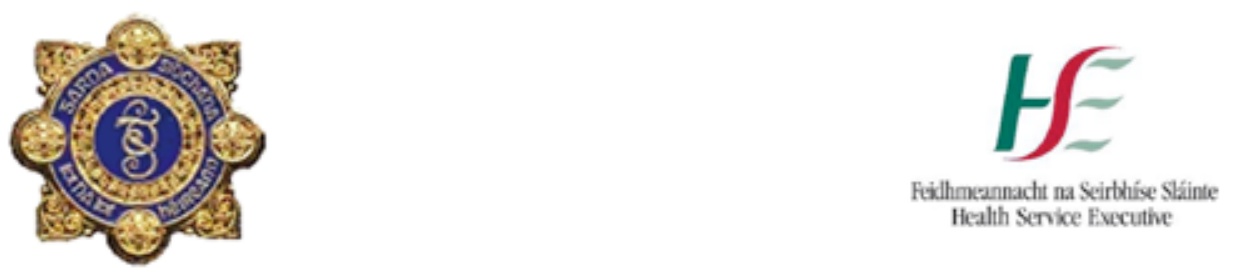

Part 1

\section{Record of Garda - HSE Liaison}

Children First: National Guidance for Protection and Welfare of Children

HSE Notification No.

Date of receipt of Formal Notification (Children First - Appendix 4/Appendix 5)

Date of Informal Notification

Child's Name

D.O.B.

Child's Address

Category of Abuse

\section{Joint Action Team (Children First - Sections 7.2/7.3)}

Designated Garda Garda Station

Designated Social Worker HSE Office

Liaison Management Team:

Garda Sergeant/Inspector

Social Work Team Leader 
Part 2

\section{Strategy Discussion on receipt of Notification}

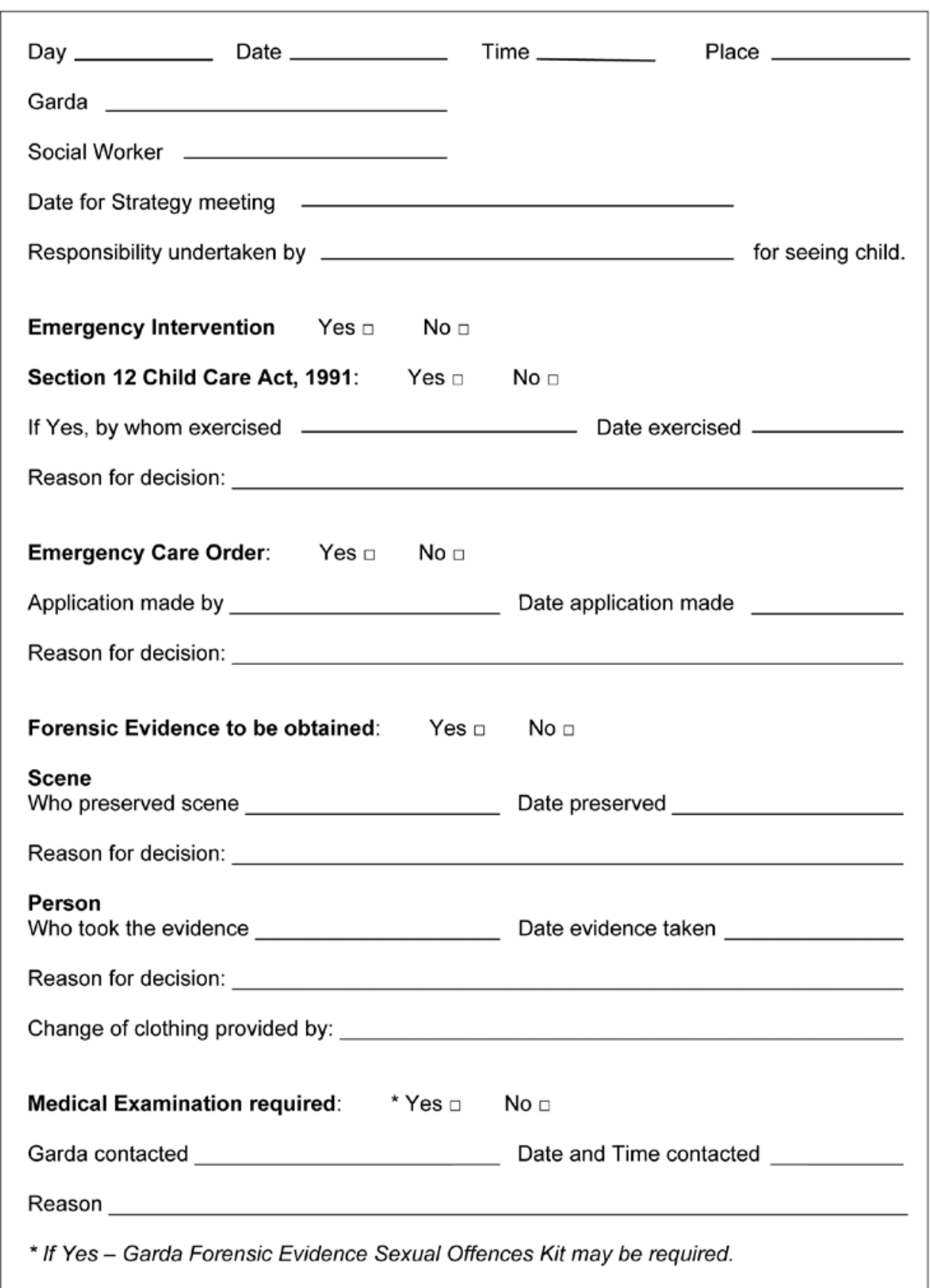


Part 3

\section{Strategy Meeting (Children First - Section 5.7)}

Convened by HSE (Children First - Paragraph 5.7.2)

Who present

Location

Day/Date/Time

DECISIONS - (Children First - Paragraph 7.14.3). Complete as appropriate.

\begin{tabular}{|l|l|l|l|l|l|}
\hline $\begin{array}{c}\text { Children First } \\
\text { Guidelines - } \\
\text { Paragraph 5.7.4 }\end{array}$ & Action & $\begin{array}{c}\text { By whom } \\
\text { action } \\
\text { carried out }\end{array}$ & $\begin{array}{c}\text { Reason for } \\
\text { action }\end{array}$ & $\begin{array}{c}\text { Date } \\
\text { completion } \\
\text { of action }\end{array}$ & $\begin{array}{c}\text { Review by } \\
\text { Liaison } \\
\text { Management } \\
\text { Team }\end{array}$ \\
\hline Information shared & & & & & \\
\hline $\begin{array}{l}\text { Immediate action to } \\
\text { protect child or } \\
\text { children }\end{array}$ & & & & & \\
\hline $\begin{array}{l}\text { Section 16(1)(b) } \\
\text { Criminal Evidence }\end{array}$ & & & & & \\
\hline Act, 1992 Interview & & & & & \\
\hline Legal options & & & & & \\
\hline
\end{tabular}


Part 3 continued

\begin{tabular}{|l|l|l|l|l|l|}
\hline $\begin{array}{c}\text { Children First } \\
\text { Guidelines - } \\
\text { Paragraph 5.7.4 }\end{array}$ & Action & $\begin{array}{c}\text { By whom } \\
\text { action } \\
\text { carried out }\end{array}$ & $\begin{array}{c}\text { Reason for } \\
\text { action }\end{array}$ & $\begin{array}{c}\text { Date } \\
\text { completion } \\
\text { of action }\end{array}$ & $\begin{array}{c}\text { Review by } \\
\text { Liaison } \\
\text { Management } \\
\text { Team }\end{array}$ \\
\hline $\begin{array}{l}\text { Protection/Supports } \\
\text { for child }\end{array}$ & & & & & \\
\hline $\begin{array}{l}\text { Sources of } \\
\text { information }\end{array}$ & & & & & \\
\hline Further enquiries & & & & & \\
\hline $\begin{array}{l}\text { Agreed plan for } \\
\text { remainder of enquiry }\end{array}$ & & & & & \\
\hline
\end{tabular}

Signed Designated Garda

Signed Designated Social Worker

If more than one strategy meeting, a new form at Part 3 to be completed in each case. 
Part 4

\section{Child Protection Conference}

Convened by HSE (Children First - Paragraph 5.8.3)

Who present

Location

Day/Date/Time

\section{Key Worker}

Child Protection Plan in place

\section{Date for Review}




\section{Part 5}

\section{Liaison Management Meeting}

\begin{tabular}{|l|l|l|l|l|}
\hline $\begin{array}{l}\text { Day/Date/ } \\
\text { Time/Place }\end{array}$ & $\begin{array}{c}\text { Progress } \\
\text { review }\end{array}$ & $\begin{array}{c}\text { Matters arising/ } \\
\text { Decisions }\end{array}$ & $\begin{array}{c}\text { Reasons for } \\
\text { decisions }\end{array}$ & Signatures \\
\hline & & & & \\
\hline & & & & \\
\hline & & & & \\
\hline
\end{tabular}


Part 6

\section{Closure of Record of Garda - HSE Liaison}

DPP Decision:

Court Date:

Court Outcome:

Reason for closure of Record of Garda - HSE Liaison:

Signed:

Designated Garda

Date:

Signed:

Designated Social Worker

Date:

Signed:

Inspector/Sergeant - Liaison Management Team

Date:

Signed:

Team Leader - Liaison Management Team

Date: 


\section{Appendix 7: Relevant Legislation}

\section{Children Act 2001}

The Children Act 2001 replaced provisions of the Children Act 1908 and associated legislation with a modern comprehensive statute. The 2001 Act covers three main areas of the law. Firstly, and predominantly, it provides a framework for the development of the juvenile justice system. Secondly, it re-enacts and updates provisions in the 1908 Act protecting children against persons who have the custody, charge or care of them. Thirdly, it provides for family welfare conferences and other new provisions for dealing with children where there is a real and substantial risk to their life, health, safety, welfare and development.

\section{Child Care Act 1991}

The purpose of the Child Care Act 1991 is to 'update the law in relation to the care of children who have been assaulted, ill-treated, neglected or sexually abused, or who are at risk'. The main provisions of the Act are:

(i) the placing of a statutory duty on the HSE to promote the welfare of children who are not receiving adequate care and protection up to the age of 18 ;

(ii) the strengthening of the powers of the HSE to provide child care and family support services;

(iii) the improvement of the procedures to facilitate immediate intervention by the HSE and An Garda Síochána where children are in danger;

(iv) the revision of provisions to enable the Courts to place children who have been assaulted, ill-treated, neglected or sexually abused, or who are at risk, in the care of or under the supervision of the HSE;

(v) the introduction of arrangements for the supervision and inspection of pre-school services;

(vi) the revision of provisions in relation to the registration and inspection of residential centres for children.

\section{Criminal Justice Act 2006}

Section 176 of the Criminal Justice Act 2006 introduced the criminal charge of 'reckless endangerment of children'. It states:

'A person, having authority or control over a child or abuser, who intentionally or recklessly endangers a child by -

(a) causing or permitting any child to be placed or left in a situation which creates a substantial risk to the child of being a victim of serious harm or sexual abuse, or

(b) failing to take reasonable steps to protect a child from such a risk while knowing that the child is in such a situation, is guilty of an offence.'

The penalty for a person found guilty of this offence is a fine (no upper limit) and/or imprisonment for a term not exceeding 10 years.

\section{Domestic Violence Act 1996}

The Domestic Violence Act 1996 introduced major changes in the legal remedies for domestic violence. There are two main types of remedies available:

(i) Safety Order: This Order prohibits a person from further violence or threats of violence. It does not oblige that person to leave the family home. If the parties live apart, the Order prohibits the violent person from watching or being in the vicinity of the home.

(ii) Barring Order: This Order requires the violent person to leave the family home.

The legislation gives the HSE the power to intervene to protect individuals and their children from violence. Section 6 of the Act empowers the HSE to apply for Orders for which a person could apply on his or her own behalf but is deterred from doing so through fear or trauma. The consent of the victim is not a prerequisite for such an application, although he or she must be consulted. Under Section 7 of the Act, the Court may, where it considers it appropriate, adjourn proceedings and direct the HSE to undertake an investigation of the dependent person's circumstances with a view to:

(i) applying for a Care Order or a Supervision Order under the Child Care Act 1991;

(ii) providing services or assistance for the dependent person's family; or

(iii) taking any other action in respect of the dependent person.

\section{Protections for Persons Reporting Child Abuse Act 1998}

This Act came into operation on 23 January 1999. The main provisions of the Act are:

(i) the provision of immunity from civil liability to any person who reports child abuse 'reasonably and in good faith' to designated officers of the HSE or to any member of An Garda Síochána;

(ii) the provision of significant protections for employees who report child abuse. These protections cover all employees and all forms of discrimination up to, and including, dismissal;

(iii) the creation of a new offence of false reporting of child abuse, where a person makes a report of child abuse to the appropriate authorities 'knowing that statement to be false'. This is a new criminal offence, designed to protect innocent persons from malicious reports. 
A wide range of nursing, medical, paramedical and other staff has been appointed as designated officers for the purposes of this Act (see Appendix 10 of the Children First: National Guidance). Section 6 of the Act is a saving provision, which specifies that the statutory immunity provided under the Act for persons reporting child abuse is additional to any defences already available under any other enactment or rule of law in force immediately before the passing of the Act.

\section{Data Protection Acts 1988 and 2003}

The Data Protection Act 1988 applies to the processing of personal data. It gives a right to every individual, irrespective of nationality or residence, to establish the existence of personal data, to have access to any such data relating to him or her, and to have inaccurate data rectified or erased. It requires data controllers to make sure that the data they keep are collected fairly, are accurate and up-to-date, are kept for lawful purposes and are not used or disclosed in any manner incompatible with those purposes. It also requires both data controllers and data processors to protect the data they keep, and imposes on them a special duty of care in relation to the individuals about whom they keep such data.

\section{Education Act 1998}

The Education Act 1998 places an obligation on those concerned with its implementation to give practical effect to the constitutional rights of children as they relate to education and, as far as practicable and having regard to the resources available, to make available to pupils a level and quality of education appropriate to meeting their individual needs and abilities.

\section{Education (Welfare) Act 2000}

The Education (Welfare) Act 2000, which was fully commenced in July 2002, replaced previous school attendance legislation and provided for the creation of a single national agency, the National Educational Welfare Board (NEWB), which has statutory responsibility to ensure that every child either attends school or otherwise receives an education or participates in training. The NEWB also assists in the formulation and implementation of Government education policy.

\section{Non-Fatal Offences against the Person Act 1997}

The two relevant provisions of this Act are:

(i) it abolishes the rule of law under which teachers were immune from criminal liability in respect of physical chastisement of pupils;

(ii) it describes circumstances in which the use of reasonable force may be justifiable.

\section{Freedom of Information Acts 1997 and 2003}

The Freedom of Information Acts 1997 and 2003 enable members of the public to obtain access, to the greatest extent possible consistent with the public interest and the right to privacy, to information in the possession of public bodies. The specific provisions of the Acts include:

(i) to provide for a right of access to records held by such public bodies, for necessary exceptions to that right and for assistance to persons to enable them to exercise it;

(ii) to enable persons to have corrected any personal information relating to them in the possession of such bodies;

(iii) to provide for independent review by an Information Commissioner both of decisions of such bodies relating to that right and of the operation of the Acts generally;

(iv) to provide for the publication by public bodies of guides to their functions and national guidelines, such as these, for the public.

Under the Acts, a person about whom a public body holds personal information has:

(i) right of access to this information, subject to certain conditions;

(ii) the right to correct this information if it is inaccurate.

Where a public body makes a decision that affects an individual, that individual has a right to relevant reasons and findings on the part of the body reaching that decision.

The Acts are also designed to protect the privacy of individuals and, in general, requires the prior consent of an individual before releasing personal information about them. Where the release of social work or medical records contains information that would be harmful to a person's well-being, the release may be made to a health professional who acts on the person's behalf. Under the Acts, there are regulations and guidelines relating to access by parents to their children's records; these emphasize that the overriding concern is the best interests of the child.

The exemptions and exclusions that are relevant to child protection include the following:

(i) protecting records covered by legal professional privilege;

(ii) protecting records that would facilitate the commission of a crime;

(iii) protecting records that would reveal a confidential source of information. 


\section{Appendix 8: Guidance for developing local child protection and welfare procedures}

In developing local guidelines, the definitions, reporting procedure and guidance on confidentiality (as provided in Chapters 2 and 3 of the Children First: National Guidance) SHOULD NOT BE CHANGED OR ADAPTED IN ANY WAY. This is because it is essential that there is consistency on definitions, the basis for reporting and the standard reporting procedure.

All organisations providing services to children when developing local procedures should ensure the following elements are included:

(i) clear descriptions of responsibility at local level, both individual and corporate;

(ii) organisation and management arrangements, as well as procedures for child protection, including arrangements for interagency cooperation;

(iii) expectations of best professional practice;

(iv) arrangements for training and support of staff;

(v) approach to family support and the involvement of the child. 


\section{Appendix 9: Guidance for employers dealing with an allegation of abuse}

When an allegation of abuse is received, it should be assessed promptly and carefully by the employer. Action taken in reporting an allegation of child abuse against an employee should be based on an opinion formed 'reasonably and in good faith'. It will be necessary to decide whether a formal report should be made to the HSE Children and Family Services. This decision should be based on reasonable grounds for concern, as outlined in Chapter 3 of this national guidance.

The first priority is to ensure that no child is exposed to unnecessary risk. The employer should as a matter of urgency take any necessary protective measures. These measures should be proportionate to the level of risk and should not unreasonably penalise the employee, financially or otherwise, unless necessary to protect children. Where protective measures penalise the employee, it is important that early consideration be given to the case.

Any action taken should be guided by agreed procedures, the applicable employment contract and the rules of natural justice.

The head of the organisation should be informed about the allegation as soon as possible.

When an employer becomes aware of an allegation of abuse of a child or children by an employee during the execution of that employee's duties, the employer should privately inform the employee of the following:

(i) the fact that an allegation has been made against him or her;

(ii) the nature of the allegation.

The employee should be afforded an opportunity to respond. The employer should note the response and pass on this information if making a formal report to the HSE Children and Family Services.

Employers or persons-in-charge should take care to ensure that actions taken by them do not undermine or frustrate any investigations/ assessments conducted by the HSE Children and Family Services or An Garda Síochána. It is strongly recommended that employers maintain a close liaison with the statutory authorities to achieve this.

Employers or persons-in-charge should be notified of the outcome of an investigation and/or assessment. This will assist them in reaching a decision about the action to be taken in the longer term concerning the employee.

The Protections for Persons Reporting Child Abuse Act 1998 makes provision for the protection from civil liability of persons who have communicated child abuse 'reasonably and in good faith' to designated officers within the HSE (see Appendix 10) or to any member of An Garda Síochána. This protection applies to organisations as well as to individuals. This means that even if a communicated suspicion of child abuse proves unfounded, a plaintiff who took an action would have to prove that the person who communicated the concern had not acted reasonably and in good faith in making the report.

A person who makes a report in good faith and in the child's best interests may also be protected under common law by the defence of qualified privilege. 


\section{Appendix 10: List of HSE Designated Officers - Protections for Persons Reporting Child Abuse Act 1998}

\section{Please see Chapter 3, Paragraph 3.10.1 of the Children First: National Guidance}

The Protections for Persons Reporting Child Abuse Act 1998 makes provision for the protection from civil liability of persons who have communicated child abuse 'reasonably and in good faith' to designated officers of the HSE or to any member of An Garda Síochána. The Chief Executive Officer of the HSE will appoint as designated officers each person falling within the following categories of officer of the HSE (details also available on HSE website, www.hse.ie):

Social Workers

Child Care Workers

Public Health Nurses

Hospital Consultants

Psychiatrists

Non-Consultant Hospital Doctors

All other HSE Medical and Dental Personnel

Community Welfare Officers

Speech and Language Therapists

All HSE Nursing Personnel

Psychologists

Radiographers

Physiotherapists

Occupational Therapists

Health Education/Health Promotion Personnel

Substance Abuse Counsellors

Care Assistants
Designated person within the HSE

Family Support Coordinators

Family Support Workers

Environmental Health Officers

Pre-school Services Inspectors

Childminder Coordinators

Managers of Disability Services

Residential Care Managers/Residential Child Care Workers

HIV and AIDS Services

Counsellors in Services for AVPA

Children First Information and Advice Persons

Children First Implementation Officers

Quality Assurance Officers

Advocacy Officers

Access Workers

Project Workers

Training and Development Officers 



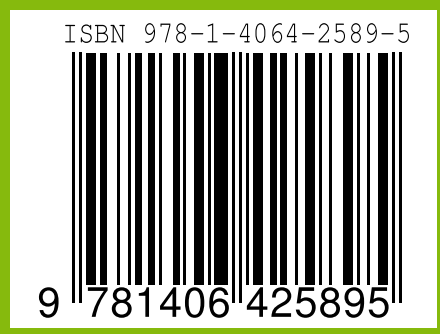

